Louisiana State University

LSU Digital Commons

1959

\title{
Holdup and Pressure Drop With Gas-Liquid Flow in a Vertical Pipe.
}

Gordon Albaugh Hughmark

Louisiana State University and Agricultural \& Mechanical College

Follow this and additional works at: https://digitalcommons.Isu.edu/gradschool_disstheses

\section{Recommended Citation}

Hughmark, Gordon Albaugh, "Holdup and Pressure Drop With Gas-Liquid Flow in a Vertical Pipe." (1959). LSU Historical Dissertations and Theses. 537.

https://digitalcommons.Isu.edu/gradschool_disstheses/537

This Dissertation is brought to you for free and open access by the Graduate School at LSU Digital Commons. It has been accepted for inclusion in LSU Historical Dissertations and Theses by an authorized administrator of LSU Digital Commons. For more information, please contact gradetd@lsu.edu. 


\section{A Dissertation}

Submitted to the Graduate Faculty of the Loui siana State University and Agricultural and Mechanical College

in partial fulfillment of the requirements for the degree of Doctor of Philosophy

in

The Department of Chemical Engineering

by:

Gordon A. Hughmark

Ch. E., University of Cincinnati, 1947

M.S. (Ch. E.), Louisiana State University, 1955

June, 1959 


\section{ACKNOWLEDGEMENTS}

Guidance in this work by Dr. Bernard Pressburg of Louisiana State University is respectfully acknowledged. The assistance of Mr. Eugene E. Snyder in constructing the test equipment is appreciated. The assistance and advise of Miss Jimmie Ward, Mr. Bernard Sobel, Dr. R. J. Laran and Dr. M B. Smith of the Ethyl Corporation in the machine calculations and the measurements of physical properties are appreciated. The author is indebted to Miss Patricia Abbott and Mr. Leslie Holmes for the preparation of the manuscript.

The trichloroethylene was generously provided by the Ethyl Corporation. 


\section{TABLE OF' CONTENTS}

\section{Page}

ACKNOWLEDGEMEIVTS

LIST OF TABLES

iv

LIST OF FIGURES

$\mathrm{V}$

ABSTRACT

vi

INTRODUCTION

I REVIEW OF THEORY

Two Phase Flow Regimes

Horizontal Flow Correlations

Vertical Flow Data and Correlations

Fundamental Vertical Two-Phase Flow Concepts

Energy. Balance for Two-Phase Vertical Flow

2

2

$\frac{3}{6}$

7

10

II EQUTPMENT, METHOD OF OPERATION AND MATERIALS 12

Equipment 12

Method of Operation $\quad 15$

Materials 17

$\begin{array}{ll}\text { III DISCUSSION AND CORRELATION OF RESULTS } & 19\end{array}$

Single-Phase Pressure Drop 19

Reliability and Reproducibility of Experimental Data 21

Holdup as a Function of Liquid Physical Properties and Flow Rate

Holdup Data Correlation

Two-Phase Pressure Drop … 38

SUMMARY AND CONCLUSIONS

NOMENCLATURE

BIBLIOGRAPHY

APPENDIX A Holdup and Pressure Drop Data 55

APPENDIX B Holdup and Pressure Drop Reproducibility Data 72

$\begin{array}{lll}\text { APPENDIX C Summary of Calculated Values } & 74\end{array}$

APPENDIX D" Sample Calculations. . . 91

AUTOBIOGRAPHY 96 
I Volume Drained from Test Section Initially Full of Liquid

II Physical Properties of Liquids Used in Two-Phase Flow Investigation

III Liquid Phase Pressure Drop 19

IV Analysis of Data for Reproducibility 24

V Summary of Coefficients and Standard Deviations for Holdup Correlation - Experimental Data

VI Summary of Coefficients and Standard Deviations for Holdup Correlation - Schwarz Data and Experimental Data

VII Summary of $R_{L}$ (Observed)- $R_{L}$ (Calculated) for Proposed Holdup Correlation

VIII Summary of Coefficients and Standard Deviations for Pressure Drop Correlation

IX Comparison of Observed and Calculated Total Pressure Drop for Experimental Runs

X Comparison of Observed and Calculated Total Pressure Drop for Literature Data 


\section{LIST OF FIGURES}

1 Diagram of Vertical Cocurrent Two-Phase Flow 9

2 Diagram of Experimental Equipment 13

3 Friction Factor Plot of Single-Phase Liquid Data 20

4 Holdup Data at a Water Mass Velocity of $128 \mathrm{Lb} / \mathrm{Sq}$ Ft Sec. 22

5 Pressure Drop Data at a Water Mass Velocity of 128

$\mathrm{Lb} / \mathrm{Sq} \mathrm{Ft} \mathrm{Sec.} \quad 23$

6 Holdup Data at a Total Mass Velocity of $150 \mathrm{Lb} / \mathrm{Sq}$ Ft Sec. 26

7 Holdup Data for Air-Water at Various Total Mass Velocities 28

8 Lockhart-Martinelli Correlation Compared to Air-Water Holdup Data

9 Holdup versus $\left(\frac{W_{L}}{W_{G}}\right)^{0.9}\left(\frac{\rho_{G}}{\rho_{L}}\right)^{0.5}$ for Water

10 Holdup versus $\left(\frac{W_{L}}{W_{G}}\right)^{0.9}\left(\left.\frac{\rho_{G}}{\rho_{L}}\right|^{0.5} \frac{1}{G^{0.435}}\right.$ for All Liquids 33

11 Correlation of Holdup Data with $\mathrm{x}$. 36

12 Correlation of Holdup Data for Vertical Air-Liquid Cocurrent Upward Flow

13 Lockhart-Martinelli Correlation Compared to Air-Water Pressure Drop Data

14 Chenoweth-Martin Correlation Compared to Air-Water Pressure Drop Data

15 Two-Phase Pressure Drop Versus Slip Velocity for Air-Water Data

16 Two-Phase Pressure Drop Versus Slip Velocity for Al工 Systems at $G=150$

17 Plot of $\frac{\triangle P T P-\triangle P I}{L}$ versus $\psi$ for $\operatorname{Slip}$ Velocity of $40 \mathrm{Ft} / \mathrm{sec}$.

18 Pressure Drop Correlation for Vertical Air-Liquid Cocurrent Upward Flow 
ABSTRACT

Vertical upward cocurrent air-liquid flow was investigated with a test section of one inch schedule 40 pipe. Pressure drop was measured with a mercury manometer connected to two pressure taps 20 ft apart in the section. The liquid under test was used as the seal fluid on the mercury. Two solenoid valves supplied air to two quick shut-off valves outside the pressure taps. Liquid drained from the section between the valves provided the holdup data. Six liquids were used in the-investigation to determine the effect of liquid density, viscosity and surface tension.

The experimental holdup and pressure drop data could not be correlated with the Lockhart-Martinelli correlation for horizontal flow. Mass velocity was shown to be an important variable that is not considered in their correlation.

A correlation for holdup was developed to include physical properties of the fluids, total mass velocity and mass flows entering the pipe. Liquid volume fraction in the pipe was correlated with a function $\mathrm{x}$.

$$
\begin{aligned}
& x=\left(\frac{W L}{W_{G}}\right)^{0.9} \frac{\mu L^{0.19} \sigma^{0.205} \rho C^{0.70} \mu G^{2.75}}{G^{0.435} \rho_{L}^{0.72}} \\
& W \quad=\text { mass rate entering pipe, } I b / s e c \text {. } \\
& \mathrm{G}=\text { total mass velocity, Ib/sq ft sec. When } \mathrm{G} \text { exceeds } 50 \text {, } \\
& \text { a value of } 50 \text { is used } \\
& \mu \quad=\text { viscosity, centipoises } \\
& \rho \quad=\text { density, } \mathrm{Ib} / \mathrm{cu} \mathrm{ft}
\end{aligned}
$$

vi 


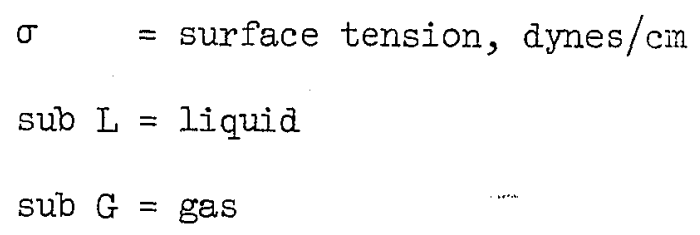

The correlation is in close agreement with the experimental and literature data. The results indicate that holdup is independent of pipe diameter in the range of 0.4 to 2.34 inches.

A pressure drop correlation was developed in which the two-phase pressure drop is a function of the difference in velocity between the two phases in the pipe with parameters of $\psi$.

$$
\begin{aligned}
& \psi=\frac{1}{G^{0.70} \mu_{I}^{0.147} \sigma^{0.194}} \\
& G \quad=\text { total mass velocity, Ib/sq ft sec. } \\
& \mu_{L} \quad=\text { Iiquid viscosity, centipoises } \\
& \sigma \quad=\text { surface tension, dynes } / \mathrm{cm}
\end{aligned}
$$

Correlation with literature data for 0.5 and 2 inch pipe indicates that $\Psi$ is inversely proportional to the square root of the pipe diameter. An average percentage error of less than $15 \%$ was obtained with the correlation between the observed data for total pressure drop and the calculated pressure drop data. 
The principle of air-water two-phase flow was applied as early as 1797 to an air lift pump invented by a German, Carl Loscher. Two-phase flow was again applied in 1927 in the Seminole, Oklahoma, oil fields to produce oil by gas lift. Two-phase flow is of continuing interest in air lift pumps, gas-oil transmission in pipe lines, and in chemical process equipment. The operation of thermosiphon reboilers depends upon two-phase flow. Lack of a good correlation for two-phase flow has limited alesign of reboilers of this type to a "rule of thumb" basis.

A large amount of data and many papers have been published on horizontal and vertical cocurrent two-phase flow. Correlations have been published that can be used with reasonable agreement for horizontal flow but there is no satisfactory method for vertical flow. Almost all vertical flow data have been obtained with the air-water system. The purpose of this study is to obtain and correlate data on two-phase systems in vertical flow with emphasis on the study of liquids with different physical properties. 


\section{CHAPTER I}

Review of Theory

Vertical cocurrent upward isothermel flow of a gas and liquid in a pipe extend from the condition of total liquid through the entire range of liquid-gas mixtures to the condition of total gas. If liquid and gas traveled at the same velocity in a pipe, two-phase flow analysis would be simple. The volume of gas in the pipe would be the same as the gas volume fed and the same with the liquid. This is not the situation. The gas phase, because of its lower density, travels at a higher velocity than the liquid phase. Thus a difference in velocity or slip velocity exists between the two phases. The difference in velocity results in an energy loss in addition to the friction loss at the wall of the pipe. Thus the friction loss for two-phase flow is usually greater than the friction loss for either fluid flowing alone.

Two-Phase Flow Regimes

Cromer ${ }^{7}$ in 1936 visually observed the flow of mixtures of air and water in a vertical pipe. He reported four types or regimes of flow.

1. Bubble flow exists when gas bubbles rise through a continuous liquid phase. This occurs at extremely low gas rates.

2. Mist flow occurs at extremely low liquid rates when droplets of liquid are suspendea in a continuous gas phase.

3. Slug flow occurs when pistons of gas are interspersed with slugs of liquid. Neither phase is continuous and a pulsat. ing flow exists.

2 
4. Annular flow occurs at high mass velocities and low to moderate liquid rates. There is an annular flow of liquid along the pipe wall with a core of gas relatively free of liquid. Both phases are continuous.

The transition between flow regimes is indistinct and it is sometimes difficult to determine the regime for a given condition.

A mathematical analysis of annular flow was attempted by Calvert. 5 Theoretical and mathematical analysis of the entire range of two-phase flow is difficult if not impossible because of the indefinite flow regimes and because of the unsteady state condition of slug flow. Thus a semi-theoretical and empirical correlation is the general approach. Horizontal Flow Correlations

Lockhart-Martinelli.

The work of Martinelli17 and co-workers provides one of the best correlations proposed for horizontal flow. Their basic postulates were stated in 1944 as follows:

1. The pressure drop for the liquid phase and the pressure drop for the gas phase must be equal regardless of the types of flow as long as appreciable pressure differences do not exist along any pipe diameter.

2. The volume occupied by the liquid and the volume occupied by the gas at any instant must equal the total volume of the pipe.

Lockhart and Martirelli15 in 1949 presented a correlation that enabled the prediction of pressure drops for horizontal flow to within plus or minus about thirty percent. The correlation for turbulent flow in both liquid and gas phases is of greatest interest. They correlated holdup, $R_{\mathrm{L}}$, and pressure drop by means of a parameter $\mathrm{X}$. 


$$
\begin{aligned}
& X=\left|\frac{W_{L}}{W_{G}}\right|^{0.9}\left|\frac{\rho_{G}}{\rho_{L}}\right|^{0.5}\left|\frac{\mu_{L}}{\mu_{G}}\right|^{0.1}=\frac{\left|\frac{\Delta P}{\Delta L}\right|_{L}}{\left|\frac{\Delta P}{\Delta L}\right|_{G}} \\
& W_{L}=\text { weight rate of liquid flow, lb/sec } \\
& W_{G}=\text { weight rate of gas flow, } I \mathrm{~b} / \mathrm{sec} \\
& \rho_{G}=\text { gas density, Ib/cu ft } \\
& \rho_{L}=\text { liquid density, Ib/cu ft } \\
& \mu_{L}=\text { liquid viscosity, lb/sec ft } \\
& \mu_{G}=\text { gas viscosity, lb/sec ft } \\
& \left|\frac{\Delta P}{\Delta L}\right|_{L}=\text { pressure drop per unit length if liquid phase flows alone } \\
& \left|\frac{\Delta P}{\Delta L}\right|_{G}=\text { pressure drop per unit length if gas phase flows alone }
\end{aligned}
$$

Holdup was plotted versus $X$. Pressure drop was contained in a function $\phi$ that was pdiotted Vs. X.

$$
\begin{aligned}
& \phi_{\mathrm{\Phi}}^{2}=\frac{\left|\frac{\Delta P}{\Delta L}\right|_{T P}}{\left|\frac{\Delta P}{\Delta L}\right|_{L}} \\
& \left|\frac{\Delta P}{\Delta L}\right|_{T P}=\text { pressure drop per unit length for two phase flow }
\end{aligned}
$$

The data included in the study by Lockhart and Martinelli are for horizontal flow in pipes from 0.62 inch to 1 inch in diameter and for pressures from 0 to 50 psig. A limited number of vertical runs were made in 0.0816 inch and 0.0586 inch tubes. The tube diameters are so small for vertical flow and the data are so limited that the correlation is considered only for horizontal flow.

Jenkins ${ }^{13}$ obtained two-phase pressure drop data from the flow of air and water at constant liquid rates. In attempting to correlate the data using Lockhart and Martinelli parameters, he found that a plot of X 
versus $\phi$ showed distinct lines for each liquid rate crossing the curve of Lockhart and Martinelli. This indicated that the mass velocity is an important variable and is not included in the Lockhart-Martinelli correlation. Chenoweth-Martin.

Chenoweth and Martin 6 in 1955 published a correlation for horizontal turbulent flow. They plotted the ratio of $\frac{\Delta P_{T P}}{\Delta P_{L^{*}}}$ versus $y_{L}$ with parameters of $\frac{\Delta P_{G}^{*}}{\Delta P_{I^{*}}^{*}}=\frac{f_{G} \rho_{L}}{f_{L} \rho_{G}^{\prime}}$

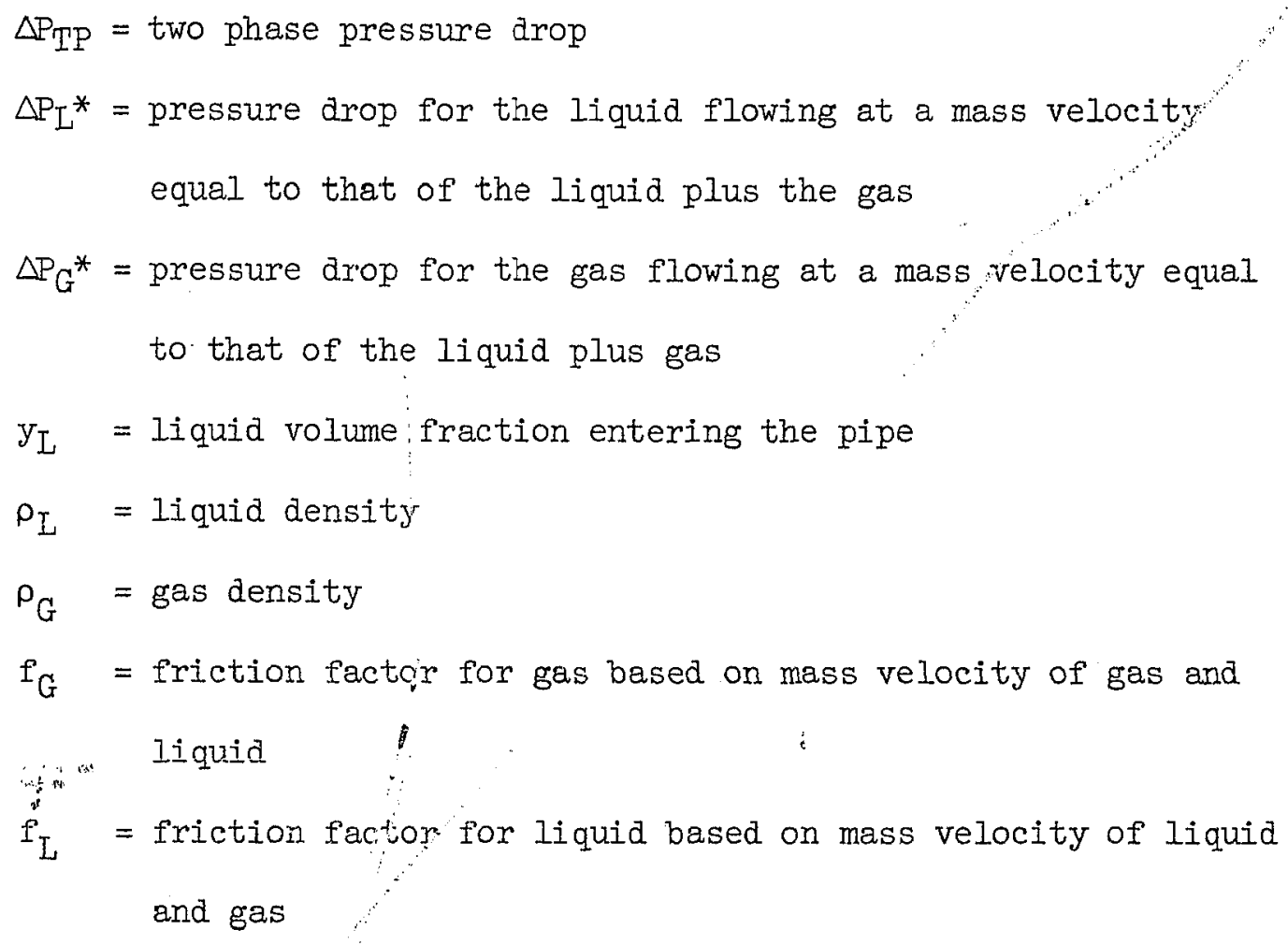
and gas

Experimental data were obtajned in $1-1 / 2$ inch and 3 inch pipes at pressures up to 100 psia. The correlation showed agreement within 20\% for these data and the data covered by Lockhart and Martinelli.

Reid ${ }^{20}$ and co-workers obtained horizontal flow data with the airwater system in 4 inch and 6 inch pipes. The 4 inch data are well represented by the Lockhart-Martinelli correlation but the 6 inch data fell about 20\% low. The data showed excellent agreement with the Chenoweth-Martin correlation and showed no noticeable effects of pipe diameter. 
Vertical Flow Data and Correlations

Schurig ${ }^{21}$ in 1934 published data on air-water in a $47 \mathrm{~mm}$ diameter tube as part of a study of two-phase flow in steam boilers.

Martinelli's success in 1944 in developing a correlation for predicting pressure drop for two-phase flow in horizontal tubes encouraged interest in the application of this correlation to vertical flow.

Kege $1^{14}$ obtained data with air and water in a copper tube one inch in diameter and 11 feet long. The fluids were maintained in the turbulent region and the data were found to agree reasonably well with the Martinelli correlation.

Dukler 8 and McElwee ${ }^{16}$ obtained vertical flow data which showed that the Martinelli correlation was satisfactory at high gas rates but useless at low air-water ratios. This observation was similar to that of Jenkins for horizontal flow in that a trend occurs with mass velocity which is not considered in the correlation.

Yagi $^{24}$ and co-workers correlated the liquid volume fraction, $\mathrm{R}_{\mathrm{L}}$, and the gas volume fraction, $R_{G}$, to the ratio of the apparent velocities of the liquid and gas. An excellent correlation is obtained over the limited range of two-phase flow investigated. The data were obtained on air-water and air-oil systems in a $10.25 \mathrm{~mm}$ diameter glass tube. Later data $^{25}$ with tube diameters of $8,12.5$ and $17.5 \mathrm{~mm}$ agreed with the original equation. Pressure arop data were also obtained and it was found that the pressure drop from the bottom to the top of the tube was linear with length. Galegar, ${ }^{10}$ Stovall and Huntington presented a correlation for the pressure drop in vertical flow based on a plot of a dimensionless flow ratio versus a friction factor.

$$
\text { flow ratio }=\frac{G_{L}}{G_{G}} \frac{\mu_{L}}{\mu_{G}}
$$




$$
\begin{aligned}
& G=\text { mass rate of gas flow referred to liquid or gas, lip/sq ft } \\
& \text { sec } \\
& \mu=\text { viscosity, } 1 \mathrm{~b} / \mathrm{ft} \mathrm{hr} \\
& f=\frac{3600 \Delta P D^{0.5} g_{C} \rho_{G} G_{L}^{2}}{2 L G_{G}^{2}} \ldots \ldots \text { (2) } \\
& f \quad=\text { friction factor } f \\
& \Delta \mathrm{P}=\text { total differential pressure across the test section } \\
& D \text { = internal diameter of pipe, ft } \\
& g_{c}=32.17 \text { (1b force) }(\mathrm{ft}) /(1 \mathrm{~b} \text { mass })\left(\mathrm{sec}^{2}\right) \\
& \mathrm{L} \quad=\text { length of test section, ft }
\end{aligned}
$$

The correlation is based on data from test sections of smooth pipe 0.1667 ft diameter by $72.25 \mathrm{ft}$ Iong and $0.04325 \mathrm{ft}$ diameter by $19.14 \mathrm{ft}$ long. Holdup and pressure drop data for the air-water system are reported by Galegar ${ }^{9}$ and pressure drop data for air-kerosene are reported by Stoval1 ${ }^{23}$. The correlation represents the data to within plus or minus 23 percent. Schwarz ${ }^{22}$ presented holdup data for the steam-water system at pressures from 20 to 80 atmospheres. The data were obtained with a tube $59.5 \mathrm{~mm}$ diameter and 4.035 meters long.

Radford ${ }^{19}$ obtained holdup and pressure drop data on the air-water system with a smooth tube 1.049 inch diameter and 22.88 feet long. Data are reported for seven series of runs at constant water rates. Govier, 11 Radford and Dunn report holdup and pressure drop data for air-water with a smooth tube 1.025 inch diameter and 22.88 feet long. These data are also obtained as a series of runs at various constant water rates.

Isbin, 12 Sher and Eddy studied the steam-water system in a 0.872 inch tube at essentially atmospheric pressure. Holdup data are reported. Fundamental Vertical Two-Phase Flow Concepts

The concept of vertical two-phase flow analysis is based on Martinelli's 17 postulates that the pressure drop for the two phases are 
equal and that the volume of liquid plus the volume of gas equals the total volume of the pipe. As shown by Figure 1, a known mass per unit time of liquid, $W_{L}$, and gas, $W_{G}$, enter the base of a pipe section at a pressure $p_{I}$. The volumes per unit time at the inlet conditions are calculated. Let

$$
\begin{aligned}
& y_{L}=\text { Iiquid volume fraction }=\frac{W_{L} v_{L}}{W_{L} v_{L}+W_{G} v_{G}} \\
& v_{L}=\text { specific volume of liquid, cu ft/lb } \\
& v_{G}=\text { specific volume of gas, cu ft/lb } \\
& y_{G}=\text { gas volume fraction, } 1-y_{L}
\end{aligned}
$$

Inside the section the gas travels at a higher velocity than the liquid. As a result the gas volume fraction in the pipe, $R_{G}$, is less than $\mathrm{y}_{\mathrm{G}}$ and the liquid volume fraction in the pipe, $\mathrm{R}_{\mathrm{L}}=1-\mathrm{R}_{\mathrm{G}}$, is greater than $\mathrm{y}_{\mathrm{L}}$. Pressure, $\mathrm{p}_{1}$, is greater at the base of the pipe than the pressure, $p_{2}$, at the top because of head and friction drop. Assuming isothermal flow, the gas volume corresponding to $\mathrm{W}_{\mathrm{G}}$ is greater at the top than at the base. Since the liquid density is constant, the gas volume fraction, $R_{G}$, must be greater at $p_{2}$ than at $p_{1}$. All experimental data indicate that $R_{G}$ increases with decreasing $u_{i}$ for a constant total mass velocity. The gas fraction, $R G$, will then be greater at $p_{2}$ than at $p_{1}$. This means that the fraction of the tube cross section area for gas flow increases upward through the pipe.

The data of Petrick ${ }^{18}$ indicate an increase in gas volume fraction upward through the pipe. Petrick studied the effect of sudden flow area changes on density. A radioactive technique was used to determine local density. Plots of the data indicate a gradual increase in gas volume fraction after recovery from the effect of sudden flow change. 
FrgITE I.

Dlagram of Vertical Cocurrent Two-Phage Flow

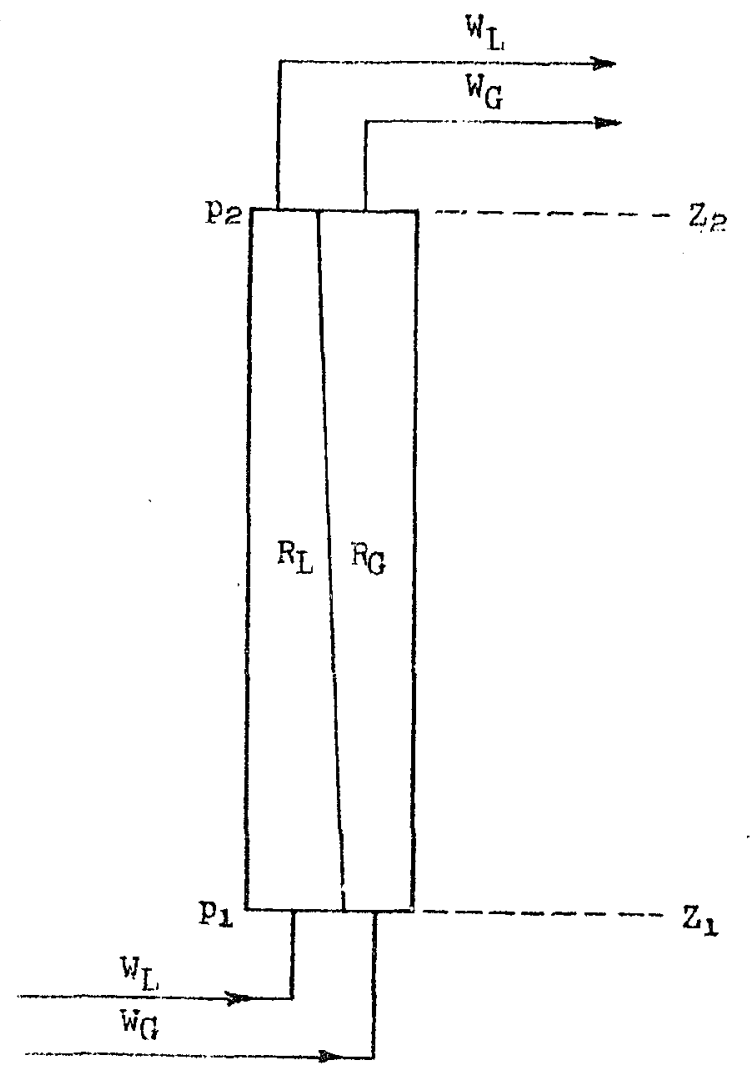

Reproduced with permission of the copyright owner. Further reproduction prohibited without permission. 
Finergy Balance for Two-Phase Vertical Flow

A mechanical energy balance for the section shown by Figure 1 is made with the assumption that steady state exists. Then $W_{L}$ pounds of Iiquid and $W_{G}$ pounds of gas enter at $I$ and leave at 2 in a given time interval. The mechanical energy balance form of the Bernoulli thereom ${ }^{4}$ is written as

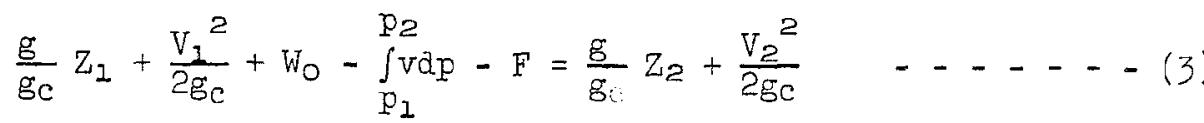

$$
\begin{aligned}
& z=\text { elevation, ft } \\
& \mathrm{V}=\text { average linear velocity of fluid flow, ft/sec } \\
& g=10: a 1 \text { acceleration of gravity, } \mathrm{ft} / \mathrm{sec}^{2} \\
& g_{c}=32.17 \text { ( } 1 \mathrm{~b} \text { force) }(\mathrm{ft}) /(1 \mathrm{~b} \text { mass })\left(\mathrm{sec}^{2}\right) \\
& \mathrm{p}=\text { absolute pressure at elevation } \mathrm{Z} \text {, Ib force/sq ft } \\
& W_{O}=\text { external work, } f t-I b \text { force } / I b \text { mass } \\
& v=\text { specific volume of system fluid cu ft/lb mass } \\
& F=\text { energy loss to friction, } \mathrm{ft}-1 \mathrm{~b} \text { force/lb mass }
\end{aligned}
$$

This equation applies to single phase flow; for liquid-gas flow the equation can be applied separately to each phase. Assume WL pounds of liquid and $W_{G}$ pounds of gas enter per unit time and $W_{0}=0$. For the liquid phase,

$$
W_{I} \frac{g}{g_{c}} z_{1}+W_{L} \frac{V_{L_{1}}^{2}}{2 g_{c}}-W_{L} \int_{p_{1}}^{p_{2}} v_{L} d p-W_{L} F_{L}=W_{I} \frac{g}{g_{c}} z_{2}+W_{L} \frac{V_{L_{2}}{ }^{2}}{2 g_{c}}--(4 a)
$$

For the gas phase,

$$
W_{G} \frac{g}{g_{c}} z_{1}+W_{G} \frac{V_{G_{1}}^{2}}{2 g_{c}}-W_{G} \int_{p_{1}}^{p_{2}} v_{G} d p-W G F G=W G \frac{g}{g_{c}} z_{2}+W G \frac{V_{G_{2}}{ }^{2}}{2 g_{c}}-(4 b)
$$

Since $v_{I}$ can be assumed constant and $v_{G}$ continually increases almost linearly as $p$ decreases, $-\int_{2} v_{1} v_{J} d p$ reduces to $-v_{L}\left(p_{2}-p_{1}\right)$ ana $-v_{G a m}\left(p_{2}-p_{1}\right)$ is a good approximation of $-\int_{p_{1}} v_{G} d p$. Where 
$v_{G_{a n}}=$ arithmeic mean of $v_{G_{I}}$ and $v_{G_{2}}$, cu ft/lb mass

Substituting and adding the equations for liquid (4a) and gas

(4b) the following equation is obtained.

$$
\begin{aligned}
\left(W_{L}+\right. & \left.W_{G}\right) \frac{g}{g_{C}}\left(Z_{2}-Z_{1}\right)+\frac{W_{I}\left(V_{L_{2}}{ }^{2}-V_{L_{1}}{ }^{2}\right)}{2 g_{C}}+\frac{W_{G}\left(V_{G_{2}}{ }^{2}-V_{G_{2}}{ }^{2}\right)}{2 g_{C}} \\
& +W_{I} F_{I}+W_{G F} F_{G}-\left(W_{L} V_{L}+W_{G V G a m}\right)\left(p_{1}-p_{2}\right)=0 \ldots(5)
\end{aligned}
$$

Assuming that $\frac{g}{g C}=I$ and dividing equation (5) through by $\left(W_{L} v_{L}+W_{G} v_{G a m}\right)$,

$$
\begin{aligned}
& \frac{\left(W_{I}+W_{G}\right)\left(Z_{2}-Z_{2}\right)}{\left(W_{L} V_{L}+W_{G V G m}\right)}+\frac{W\left(V_{L_{2}}{ }^{2}-V_{L}{ }^{2}\right)+W_{G}\left(V_{G}{ }^{2}-V_{G_{1}}{ }^{2}\right)}{2 g_{c}\left(W_{T} V_{T}+W_{G} V_{G a m}\right)} \\
& +\frac{W_{I F L}+W_{G F G}}{\left(W_{L} V I+W_{G} G_{a m}\right)}-\left(p_{1}-p_{2}\right)=0 \ldots \ldots
\end{aligned}
$$

Then defining

$$
\begin{aligned}
& \Delta P_{T P}=\frac{W_{I F L}+W_{G F G}}{\left(W_{L} V_{L}+W_{G} V_{a m}\right)} \text { where } \\
& \Delta P_{T P}=\text { two phase pressure drop, } 1 \mathrm{~b} \text { force/sq ft }
\end{aligned}
$$

the following general equation is obtained for liquid-gas two-phase flow:

$$
\begin{aligned}
& \frac{\left(W_{L}+W_{G}\right)\left(Z_{2}-Z_{1}\right)}{\left(W_{I} V_{L}+W_{G} V_{a m}\right)}+\frac{W_{L}\left(V_{I_{2}}{ }^{2}-V_{L_{1}}{ }^{2}\right)+W_{G}\left(V_{G_{2}}{ }^{2}-V_{G_{1}}{ }^{2}\right)}{2 g_{c}\left(W_{I_{L}} V_{L}+W_{G} V_{G_{a m}}\right)} \\
& +\triangle P T P-\left(p_{1}-p_{2}\right)=0
\end{aligned}
$$

Equation (7) as derived in this Chapter wiII be applied later to correlate the new data reported herein for vertical liquid-gas two-phase flow. 
CHAPTER II

Equipment, Method of Operation and Materials

Holdup and pressure drop data for cocurrent vertical air-liquid flow were obtained for a 20 foot section of one inch schedule 40 steel pipe. Flow rates studied ranged from 0.01 to 40 SCFM of air and from 0.05 to $7 \mathrm{gpm}$ of liquid.

Equipment

The equipment is shown by Figure 2 .

Air was drawn from the receiver of an air compressor which operated to deliver air between the limits of 70 and 95 psig. Air from the receiver passed through a Commercial Filters Corporation Fulflo Filter to remove entrained oil and water. The air was then regulated by: a pressure reducer to supply $50 \mathrm{psig}$ air to the rotameters. The most appropriate of three rotameters, connected in parallel, was used to give maximum accuracy of measurement in the range of air flow desired for a specific test. A valve cownstream from each meter was used for control. The metered air then entered the base of the test section as shown by Figure 2 .

Liquid was drawn from a 55 gallon drum by a rotary pump and discharged through either of two parallel rotameters. A by-pass from the pump discharge to the suction was used to circulate the liquid discharged by the positive displacement pump but which was not fed to the test section. Flow through each rotameter was controlled by a valve downstream from the meter. The metered liquid then entered the base of the test section. 
FIGURE 2

Diagram of Experimental Equipment

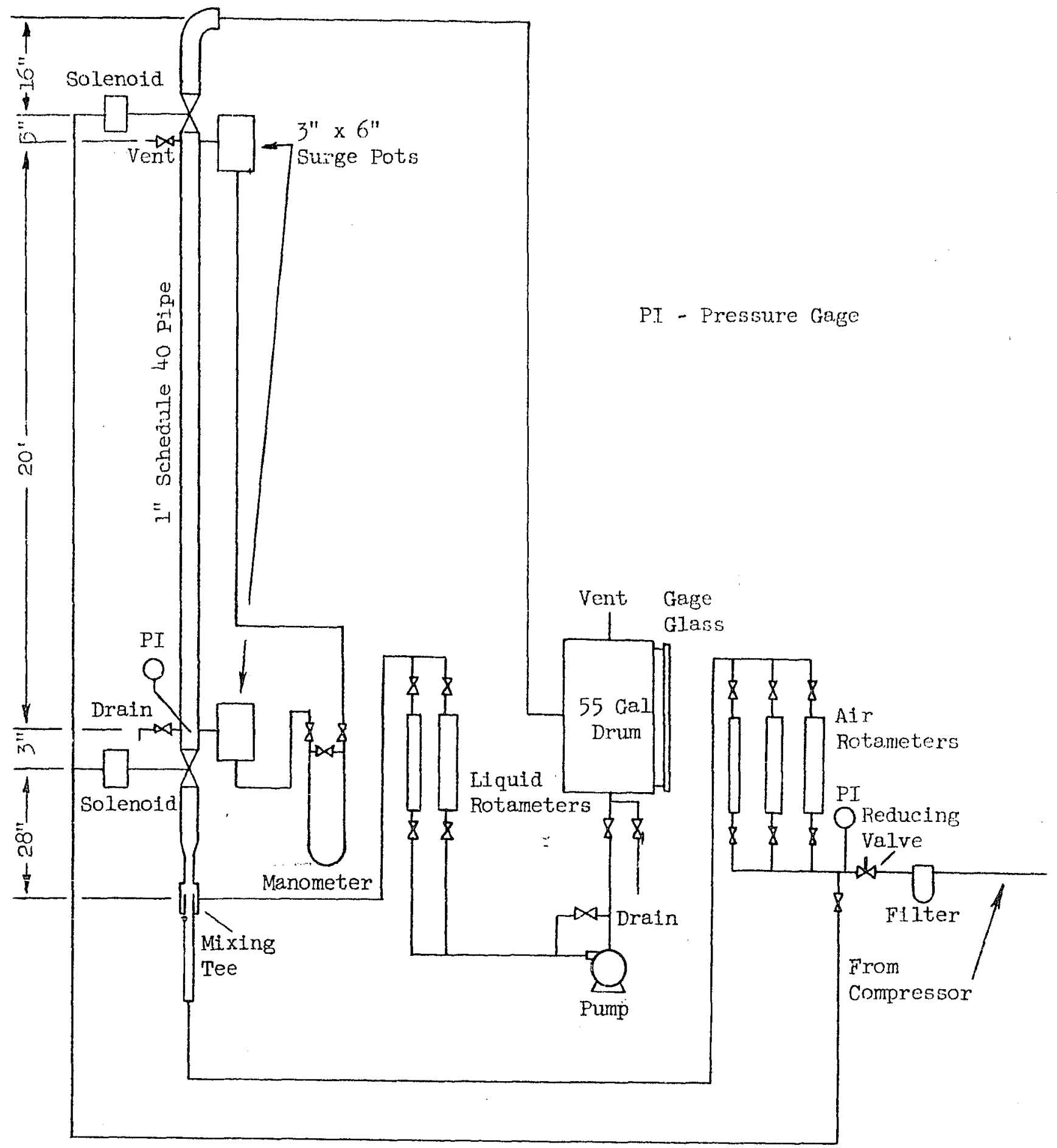


The vertical test section itself was a 24.2 foot long run of one inch schedule 40 steel pipe witn pressure taps 20 feet apart. The bottom pressure tap was 28 inches above the air-liquid mixing nozzle. Surge pots 3 inches in diameter by 6 inches long were installed with the tap from the test section entering the side of the pot. The outlet from the bottom of each pot was connected with copper tubing to a 30 inch aifferential manometer which used mercury as the metering element. The portion of the pots below the taps and the copper tubing were filled with the test liquid as a seal fluid in the mercury. The diameter of the surge pots was selected so that the cross sectional area of the pots was about 200 times the cross sectional area of the manometer. A change in manometer level thus reflected a negligible change in level in the surge pot.

One quick shut-off valve was installed below the bottom pressure tap and a second above the top pressure tap. Both valves were one inch Valvair Corporation two-way valves, normally open. Each valve was operated by a three way solenoid air-valve. Air at 50 psig was supplied to the solenoid valves. Both solenolds were operated from a single electrical connection. When this was closed, air was supplied to the air operated valves and caused immediate, simultareous and tight shut off. The air operated valves were opened by breaking the electrical connection, the resultant action blocking the air at the solenoid valves and venting the air from the valves. To insure similtaneous and uniform closure, the solenoid valves were installed so that the air piping between the solenoid valve and its component air operated valve was identical for both.

A pressure gage was installed in the test section at the elevation of the bottom pressure tap. A drain connection was provided above the bottom valve and a vent was installed below the top valve. After the valves were closed, the vent valve was opened and the liquid in the section was drained through the drain connection. 
Flow from the top of the test section passed to the holdup drum. Air separated from the liquid in the drum and was vented to the atmosphere through a coupling in the top of the drum. Liquid was recirculated from a connection in the bottom of the drum.

The air rotameters were calibrated by a timed air displacement of water in an inverted transparent container. Liquid rotameters were calibrated for each liquid by a timed weighing of the liquid. The zero points for the manometer were obtained for each liquid by obtaining a reading with the test section filled with liquid at zero flow and from a reading with liquid completely drained from the section. When the difference between the two readings, corrected for the seal liquid, corresponded to the calculated liquid head in the section, it was assumed that the leads were uniformly filled with the seal fluid. Method of Operätion

The desired liquid flow for a run was metered to the test section through use of the liquid rotameter. After the manometer had reached a steady reading, the desired gas flow was metered with the gas rotameter. . Steady state of most of the two-phase runs was obtained in less than one minute. Runs at high liquid rates and very low air rates required several minutes to reach steady state conditions as shown by the manometer. The rotameter readings, manometer reading and pressure gage reading were recorded for each run. The valves were closed, the vent was opened and the liquid was drained from the test section to a two liter graduated cylinder. The volume of liquid drained from the test section was recorded.

Data for the runs are tabulated in Appendix A. Air flow is recorded as the CFM of air flowing through the test section at a pressure equal to the average of the pressures at the top and bottom taps. Liquid flow is in cubic feet per minute flowing through the section. Pressure as 
tabulated is the reading of the pressure gage at the bottom of the section. Pressure drop is the actual pressure differential between the two taps. This was determined from the manometer reading.

The volume of the test section was determined to be $3570 \mathrm{cc}$. Complete drainage of water showed a holdup of $3550 \mathrm{cc}$ above the drain connection. Calculated holdup between the bottom valve and the drain connection was $20 \mathrm{cc}$.

Two corrections were applied to the liquid volume drained from the section to obtain the total liquid holdup. These were:

1. Twenty cc was added to account for the liquid remaining in the section between the valve and drain connection.

2. Volume was added to account for the liquid adhering to the wall of the pipe after draining. This measurement was made for each liquid. The section was filled with the liquid and then drained. The difference between this volume and the known volume of $3550 \mathrm{cc}$ for complete drainage was assumed to be the amount of liquid still adhering to the pipe wall after draining for each run with that liquid. These data are tabulated in Table I.

TABIE I

Volume Drained from Test Section Initially Full of Liquid

$\longrightarrow$ Liquid

Water

Sodium Carbonate Solution Varsol Oil Blend No. 1 Oil Blend No. 2 Prichloroethylene

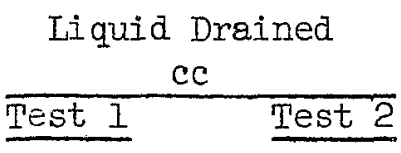

$3550 \quad 3550$

$3520 \quad 3525$

$3480 \quad 3480$

$3480 \quad 3480$

$3470 \quad 3470$

$3550 \quad 3550$

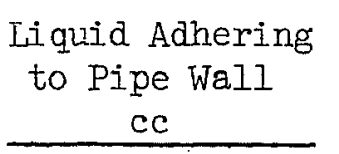

It quid Adhering

ce

25

70

70

80 
Air and liquid temperatures during the entire series of runs varied between $70^{\circ}$ and $80^{\circ} \mathrm{F}$. Air fed to the test section was saturated with water at the 70 psig air receiver pressure. Vaporization of liquid in the test section was considered to be negligible for all runs. Materials

Runs were made with air and six different liquids. The liquids were selected to vary the physical properties of density, viscosity and surface tension. Because of the extremely turbulent nature of two-phase flow, dynamic rather than static surface tension would be expected to be an important variable. Therefore, use of surface active agents was purposely avoided in this investigation.

Table II lists the six liquids tested and gives their density, viscosity and surface tension.

TABLE II

Physical Properties of Liquids Used in Two-Phase Flow Investigation

\begin{tabular}{|c|c|c|c|}
\hline Material & $\begin{array}{l}\text { Density } \\
\mathrm{Lb} / \mathrm{Cu} \mathrm{Ft}\end{array}$ & $\begin{array}{c}\text { Viscosity } \\
\text { Centipoises } \\
\end{array}$ & $\begin{array}{l}\text { Surface } \\
\text { Tension } \\
\text { Dynes/cm }\end{array}$ \\
\hline$a t$ & 2.4 at $25^{\circ} \mathrm{C}$ & 0.90 at $25^{\circ} \mathrm{C}$ & 72.5 at $25^{\circ} \mathrm{C}$ \\
\hline Sodium Carbonate Solution & 74 at $25^{\circ} \mathrm{C}$ & 3.15 at $23.9^{\circ} \mathrm{C}$ & 75.9 at $25^{\circ} \mathrm{C}$ \\
\hline Varsol & 48.5 at $25.5^{\circ} \mathrm{C}$ & 1.07 at $25^{\circ} \mathrm{C}$ & 24.9 at $25^{\circ} \mathrm{C}$ \\
\hline Oil Blend No. 1 & 51.5 at $24^{\circ} \mathrm{C}$ & 5.83 at $24.4^{\circ} \mathrm{C}$ & 27.4 at $25^{\circ} \mathrm{C}$ \\
\hline Oil BIend No. 2 & 54.2 at $25^{\circ} \mathrm{C}$ & 28.6 at $25^{\circ} \mathrm{C}$ & 29.9 at $25^{\circ} \mathrm{C}$ \\
\hline Trichloroethylene & 88.9 at $24^{\circ} \mathrm{C}$ & 0.55 at $25^{\circ} \mathrm{C}$ & 28.8 at $25^{\circ} \mathrm{C}$ \\
\hline
\end{tabular}

Density was determined by weighing one liter of the liquid in a one liter volumetric flask. The viscosity of water and trichioroethylene and the surface tension of water were obtained from data reported in the Iiterature. ${ }^{3,4}$ The remaining viscosity and surface tension measurements were made on samples of the Iiquid by the Physical Data Group of the Ethyl Corporation. Viscosity was obtained with a Brookfield Viscosimeter with a special adapter for low viscosities. Surface tension was determined 
with the Findlay surface tension apparatus using the capillary rise method. Water runs were made with Baton Rouge city water. A solution of about 18 weight percent soda ash in water was used for the sodium carbonate solution runs. Varsol was used in a series of tests. Oil Blend No. 1 was prepared by adding 10 gallons of SAE 20 oil to about 10 gallons of Varsol. Six gallons of SAE 50 oil was added to about 10 gallons of Oil Blend No. 1 to obtain Oil Blend No. 2. Trichloroethylene for these runs was provided by the Ethyl Corporation. 
CHAPTER III

Discussion and Correlation of Results

Single-phase pressure drop results for the test section are presented and discussed. The reliability of the two-phase data is evaluated. Observed effects of liquid physical properties are discussed. Holdup data are compared with the Lockhart-Martinelli correlation and a new correlation for holdup is developed. Pressure drop data are compared with the Lockhart-Martinelli and Chenoweth-Maxtin correlations. A new pressure drop correlation is developed.

Single-Phase Pressure Drop

As a limiting case and as a means of comparing with single-phase flow, pressure drops were determined for the $20 \mathrm{ft}$ test section with liquid flow and zero air flow. The results are tabulated in Table III.

TABLE III

Liquid Phase Pressure Drop

\begin{tabular}{|c|c|c|c|c|}
\hline Liquid & $\begin{array}{l}\text { Mass Velocity } \\
\mathrm{Lb} / \mathrm{sq} \mathrm{Ft} \text { Sec. }\end{array}$ & $\begin{array}{l}\text { Pressure Drop } \\
\text { to Friction, } \\
\text { In. Hg } \\
\end{array}$ & $\begin{array}{l}\text { Reynolds } \\
\text { Number } \\
\end{array}$ & $\begin{array}{c}\text { Friction } \\
\text { Factor } \\
\quad 1 \\
\end{array}$ \\
\hline Water & 150 & 0.57 & 20,300 & 0.031 \\
\hline $\mathrm{Na}_{2} \mathrm{CO}_{3}$ Solution & 150 & 0.60 & 6,200 & 0.039 \\
\hline Varsol & 150 & 0.70 & 18,200 & 0.0303 \\
\hline Varsol & 100 & 0.325 & 12,100 & 0.0314 \\
\hline Oil Blend No. I & 150 & 0.88 & 3,770 & 0.040 \\
\hline Oil BIend No. 2 & 150 & 2.0 & 680 & 0.090 \\
\hline Oil Blend No. 2 & 100 & 1.35 & 455 & 0.145 \\
\hline Oil Blend No. 2 & 50 & 0.68 & 225 & 0.293 \\
\hline Trichloroethylene & 150 & 0.355 & 35,400 & 0.028 \\
\hline
\end{tabular}

These data are shown as a typical friction factor plot in

Figure 3. The solid line for the turbulent flow region represents the 


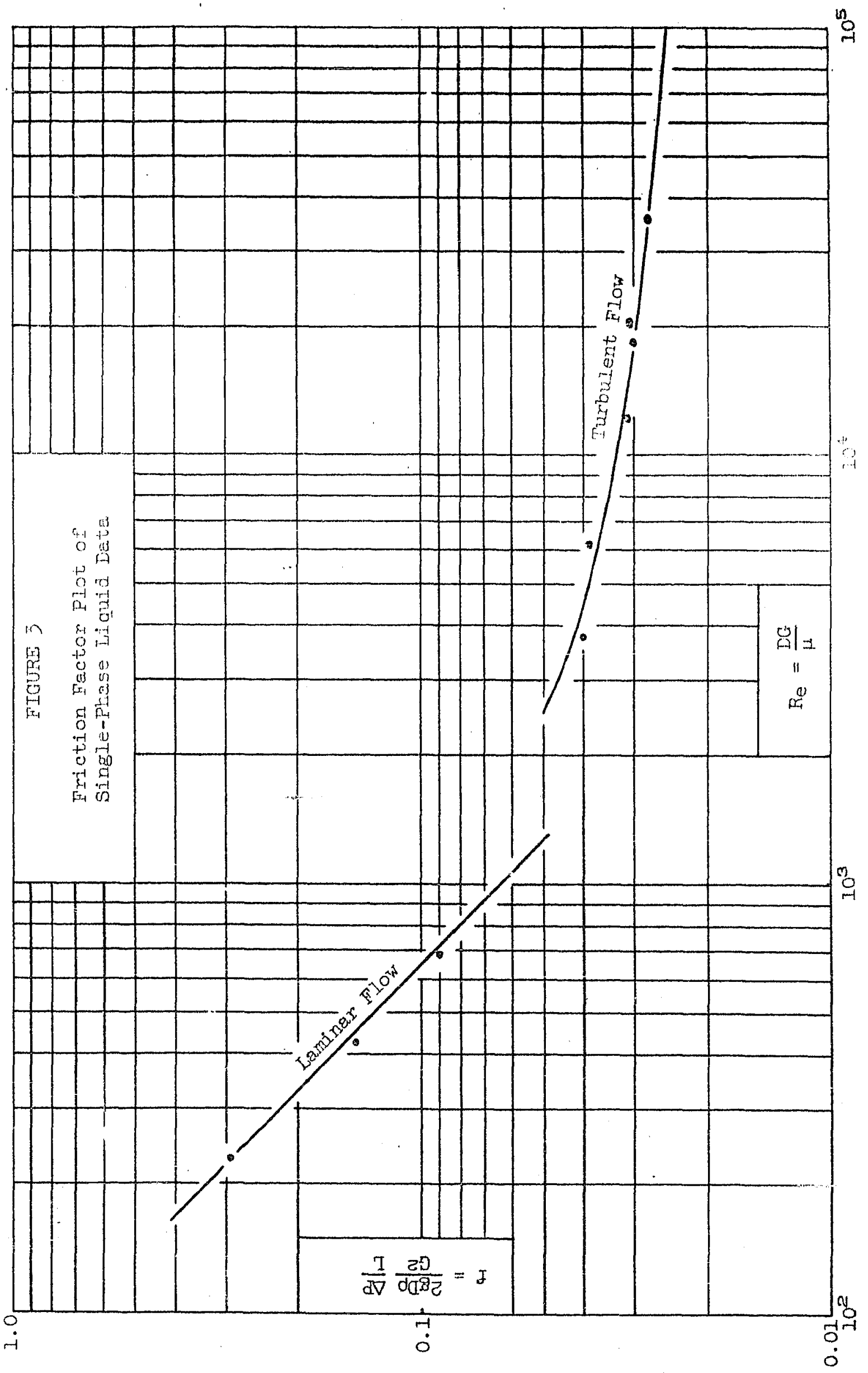


friction factor for a relative roughness of $0.002,{ }^{2}$ corresponding to a one inch commercial steel pipe. Data for the laminar flow region are shown in comparison to the line for $f=\frac{64}{R_{e}}$ which is Poiseuille's law in comparable units.

Reliability and Reproducibility of Experimental Data

Govier, Radford, and Dunn ${ }^{I I}$ present data for the air-water system at a water mass velocity of $128 \mathrm{lb} / \mathrm{sq}$ ft sec. Their test section was a $22.88 \mathrm{ft}$ length of 1.025 inch smooth pipe. In the present study, a series of check runs were made at a constant water mass velocity of $128 \mathrm{lb} / \mathrm{sq} \mathrm{ft}$ sec. to compare with this published data. The resulting holdup data are shown by Figure 4 and the pressure drop data by Figure 5 . Very close agreement can be noted for the holdup data. The observed pressure drops are approximately $20 \%$ higher than those of Govier et al., as would be expected for data from a commercial pipe in comparison to a smooth pipe.

Reproducibility of the experimental data was ascertained by obtaining data from five runs with identical liquid and air feed rates. Four groups of five identical runs were made for several conditions of airwater flow and one group of five identical runs was made for each of the other Iiquids tested. The data are presented in Appendix B and a summary of the statistical analysis of the data in Table IV. In order to avoid bias, runs in the first seven groups were purposely made so that no two runs in the same group were consecutive. Data for several groups rere taken on three different days. Groups 1, 2 and 3 show the reproducibility for the air-water system with three different values of $\mathrm{y}_{\mathrm{L}}$. Groups $I$ and 4 compare total mass velocities of 25 and 50 for air-water with the same $\mathrm{y}_{\mathrm{L}} \cdot$ Groups 1, 5, 6, 7,8, and 9 show the effect of the different liquids. Ninety percent of the data would be expected to fall within plus or minus two standard deviations of the mean for a " $t$ " distribution. For $R_{L}$ data, 


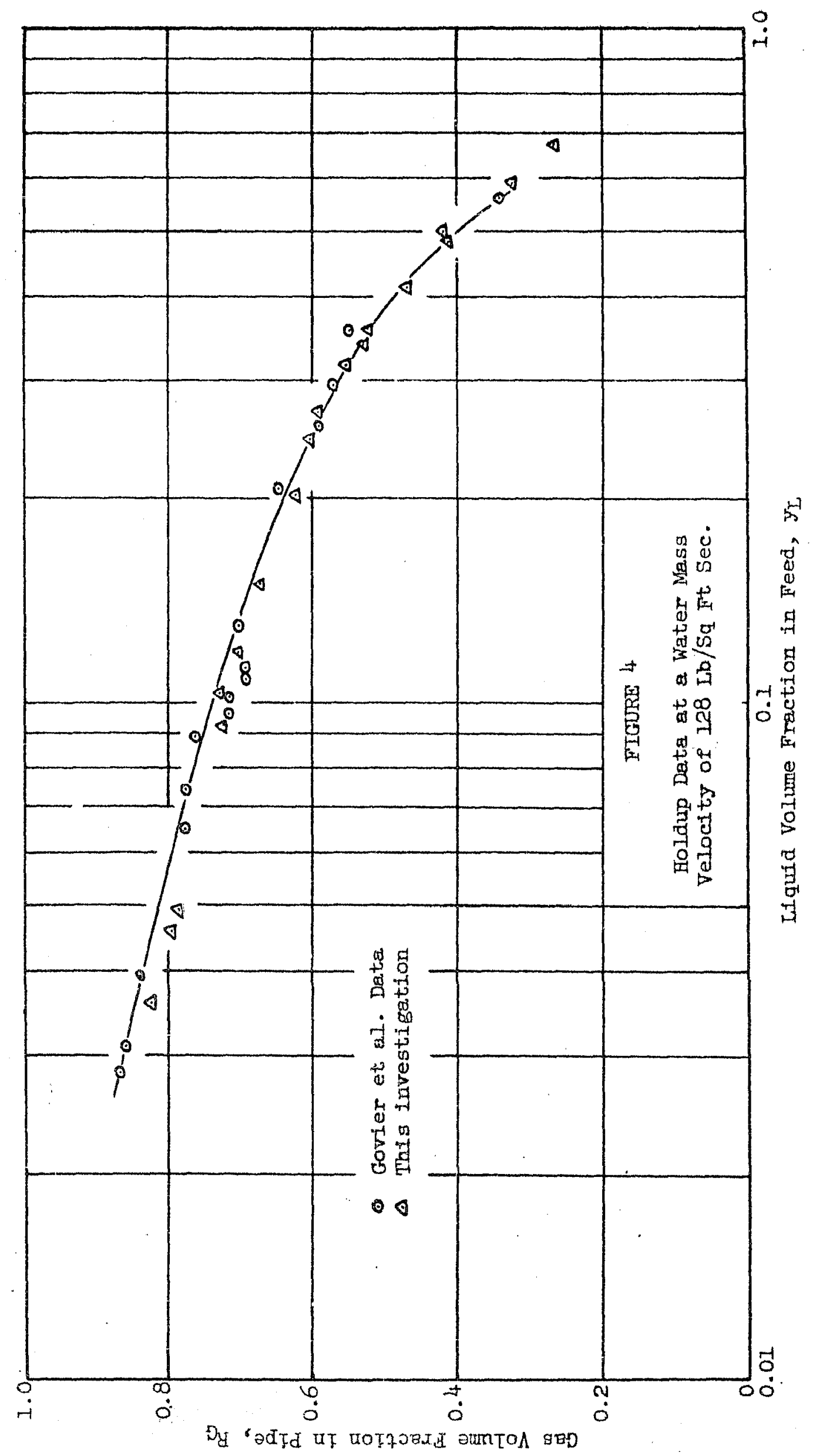

Reproduced with permission of the copyright owner. Further reproduction prohibited without permission. 


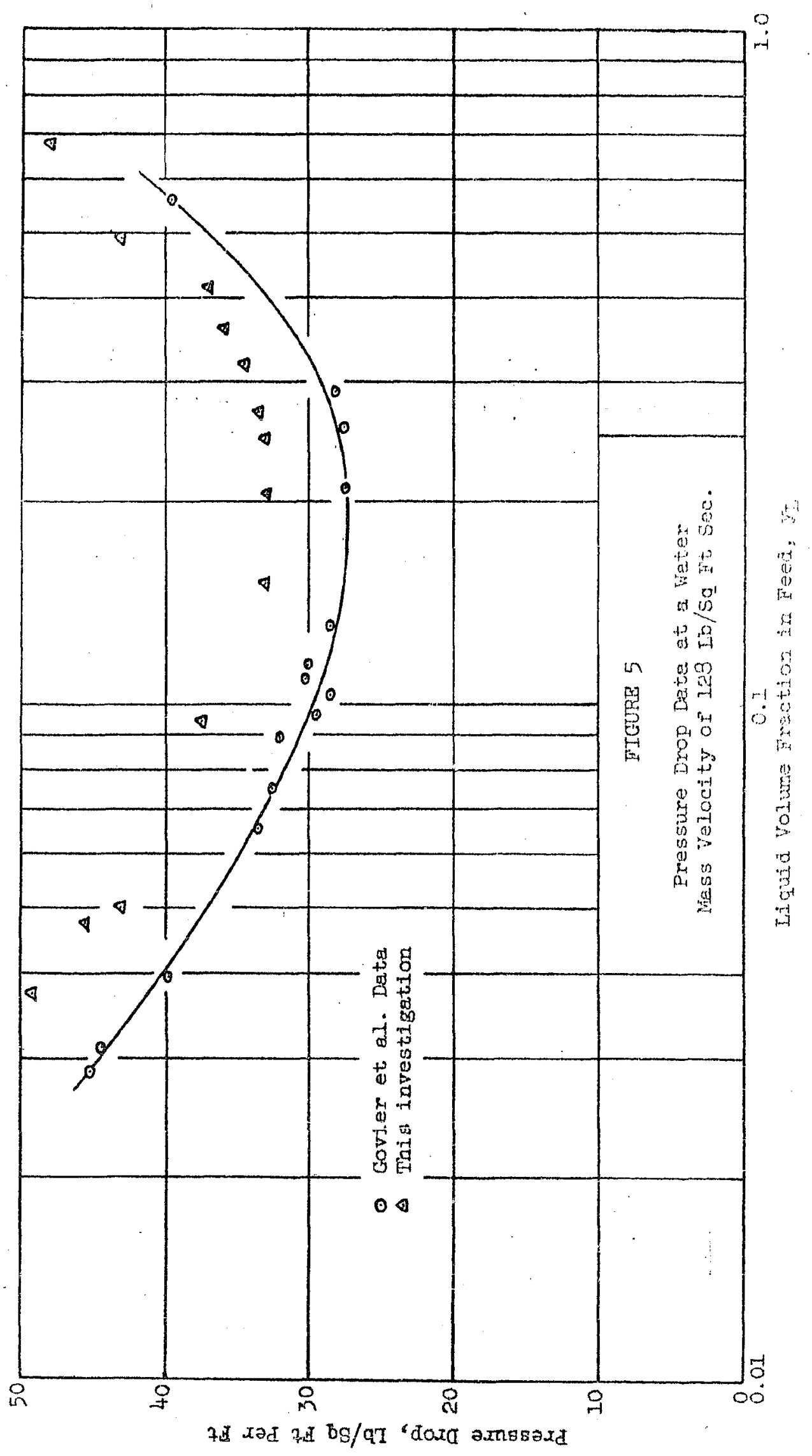

Reproduced with permission of the copyright owner. Further reproduction prohibited without permission. 
TABTE IV

Analysis of Data for Reproducibility

\begin{tabular}{|c|c|c|c|c|c|c|c|c|}
\hline Group & Run Number & Iiquid & $G$ & $\mathrm{yJ}_{2}$ & Mean RL & $\begin{array}{l}\text { Standard } \\
\text { Deviation } \\
R_{L} \\
\end{array}$ & $\begin{array}{l}\text { Mean } \triangle P, \\
\text { In. Hg }\end{array}$ & $\begin{array}{l}\text { Standard } \\
\text { Deviation } \\
\triangle P \text {,In. Hg } \\
\end{array}$ \\
\hline$I$ & $\begin{array}{l}248,251,256, \\
259,262\end{array}$ & Water & 25 & 0.378 & 0.5854 & 0.0055 & 9.89 & 0.055 \\
\hline 2 & $\begin{array}{l}249,255,258, \\
260,266\end{array}$ & Water & 25 & 0.053 & 0.2574 & 0.0087 & 4.34 & 0.23 \\
\hline 3 & $\begin{array}{l}245,250,257, \\
261,268\end{array}$ & Water & 25 & 0.0042 & 0.08082 & 0.0125 & 3.67 & 0.09 \\
\hline 4 & $\begin{array}{l}269,275,281 \\
288,296\end{array}$ & Water & 50 & 0.378 & 0.5050 & 0.0111 & 8.66 & 0.13 \\
\hline 5 & $\begin{array}{l}346,405,408, \\
424,430\end{array}$ & $\mathrm{Na}_{2} \mathrm{CO}_{3}$ Solution & 25 & 0.378 & 0.631 & 0.0207 & 12.06 & 0.44 \\
\hline 6 & $\begin{array}{l}588,591,610, \\
613,616\end{array}$ & Varsol & 25 & 0.378 & 0.5256 & 0.0111 & 7.07 & 0.097 \\
\hline 7 & $\begin{array}{l}805,808,811, \\
814,817\end{array}$ & OiI Blend No. I & 25 & 0.378 & 0.5657 & 0.0086 & 7.82 & 0.083 \\
\hline 8 & $957-961$ & Oil Blend No. 2 & 25 & 0.363 & 0.7258 & 0.0088 & 10.08 & 0.067 \\
\hline 9 & $1025-1029$ & Trichloroethylene & 37.5 & 0.378 & 0.5232 & 0.0056 & 18.24 & 0.043 \\
\hline
\end{tabular}


two standard deviations vary from a minimum of 0.011 for Group $I$ to a maximum of 0.041 for Group 5. For pressure drop, two standara deviations vary from $10.6 \%$ of the mean for Group 2 to $0.47 \%$ for Group 9 . There does not appear to be any significant effect of liquid characteristics, total mass velocity or $\mathrm{yL}_{\mathrm{L}}$ on the reproducibility of the data.

The standard deviations were obtained from

$$
\begin{aligned}
& \sigma_{0}^{2}=\frac{\Sigma X^{2}}{(N-I)}-\frac{(\Sigma X)^{2}}{N(N-I)} \ldots \ldots . \cdots \\
& \sigma_{0}=\text { standard deviation } \\
& \Sigma X^{2}=\text { sum of squares of } \mathrm{R}_{\mathrm{L}} \text { or } \Delta \mathrm{P} \text { for a group } \\
& \Sigma \mathrm{X}=\text { sum of } \mathrm{R}_{\mathrm{L}} \text { or } \Delta \mathrm{P} \text { for a group } \\
& N=\text { number of runs in the group. }
\end{aligned}
$$

Holdup As A Function of Liquid Physical Properties and Flow Rate

The object for the experimental program was as follows:

1. To obtain holdup and pressure drop data for a range of $\mathrm{y}_{\mathrm{L}}$ at a constant total mass velocity with a given liquid.

2. To repeat 1 at several total mass velocities with the same liquid.

3. To repeat 1 and 2 for each liquid tested.

Mass velocity was considered as an important variable because Jenkins'13 data showed a parallel trend from the Lockhart-Martinelli correlation with liquid mass velocity as a parameter. Review of vertical data in the literature 10,11 showed the same trend with mass velocity. However, total mass velocity was found to give a more parallel trend than liquid mass velocity alone. For this reason, total mass velocity was used in obtaining the experimental data.

Figure 6 shows holdup, $R_{G}$, as a function of $y_{L}$ at a total mass velocity of $150 \mathrm{lb} / \mathrm{sq} \mathrm{ft}$ sec. for all of the liquids tested. The dotted 


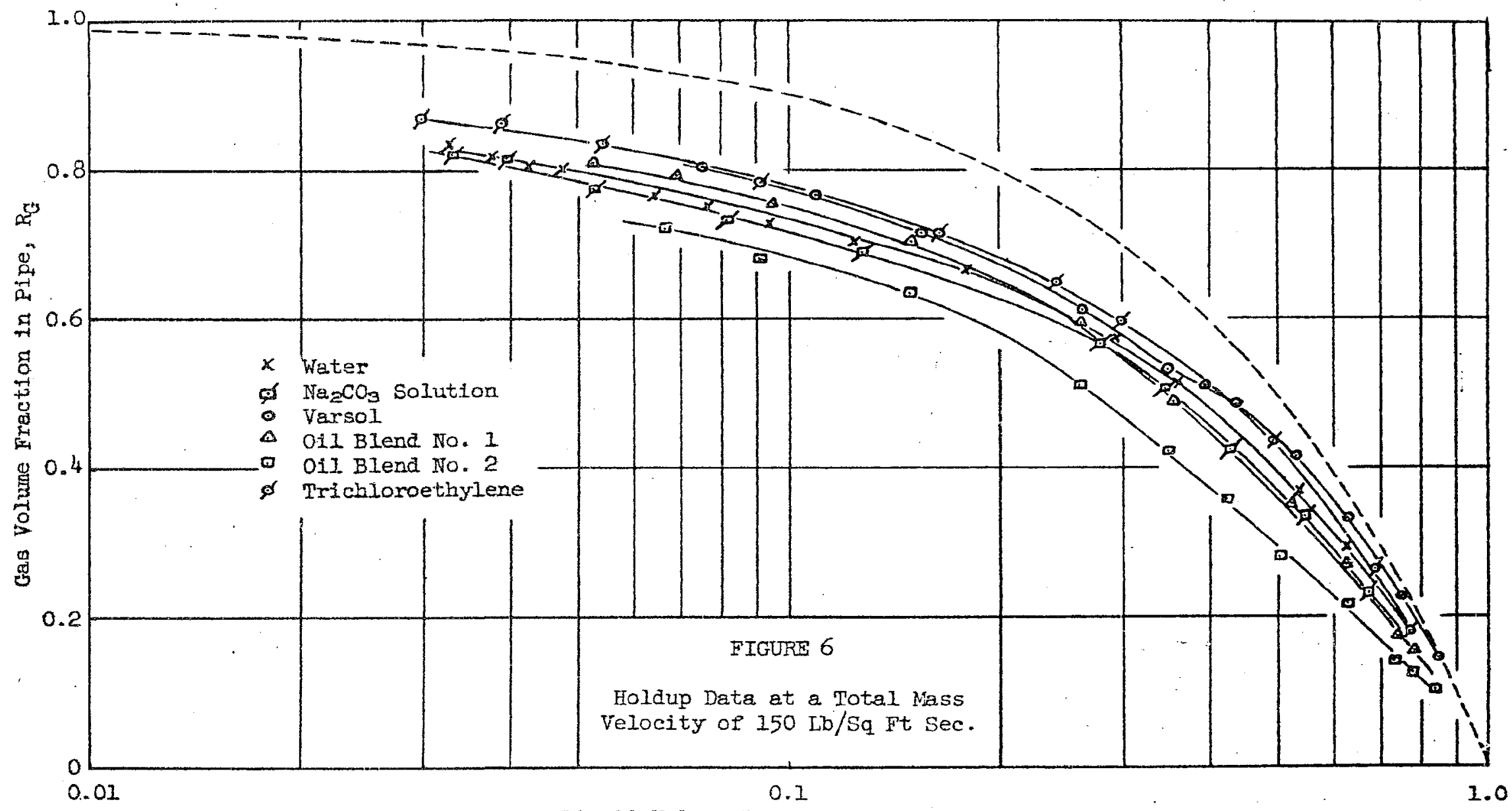

Liquid Volume Fraction in Feed, $\mathrm{y}_{\mathrm{L}}$ 
line indicates $R_{G}$ for no difference in velocity between the phases, which is the limiting case in which $R_{G}=y_{G}=1-y_{L}$. The observed data approach this condition as $y_{I}$ approaches 1 . As shown by Figure 6 the liquids appear to give the following order of increasing difference between $R_{G}$ and $y_{G}$ for a constant value of $\mathrm{y}_{\mathrm{L}}$. The properties of these liquids, as measured, are included to explain their behavior.

$\begin{array}{llll} & \rho & \mu & \sigma \\ \text { 1. Trichloroethylene } & 88.9 & 0.55 & 28.8 \\ \text { 2. Varsol } & 48.5 & 1.07 & 24.9 \\ \text { 3. Oil Blend No. I } & 51.5 & 5.83 & 27.4 \\ \text { 4. Water } & 62.4 & 0.9 & 72.5 \\ \text { 5. Sodium Carbonate Solution } & 74.0 & 3.15 & 75.9 \\ \text { 6. Oil Blend No. 2 } & 54.2 & 28.6 & 29.9\end{array}$

Varsol, Oil Blend No. I and Oil Blend No. 2 have approximately the same density and surface tension. From a comparison of these, it can then be concluded that the difference between $R_{G}$ and $y_{G}$ increases with liquid viscosity. In fact, except for water and sodium carbonate solution, consideration of the tabulation shows an increase in this difference with increasing liquid viscosity. The fact that water and sodium carbonate solution show a greater difference between $R_{G}$ and $y_{G}$ that is inconsistent in terms of viscosity, also indicates that another physical property must contribute. Both these liquids have high surface tensions, which suggests that the difference between $R_{G}$ and $y_{G}$ must increase with increasing surface tension. The effect of liquid density is not obvious.

Figure 7 shows the holdup for water at three different total mass velocities. It is apparent that the difference between $R_{G}$ and $y_{G}$ increases as the total mass velocity decreases. 


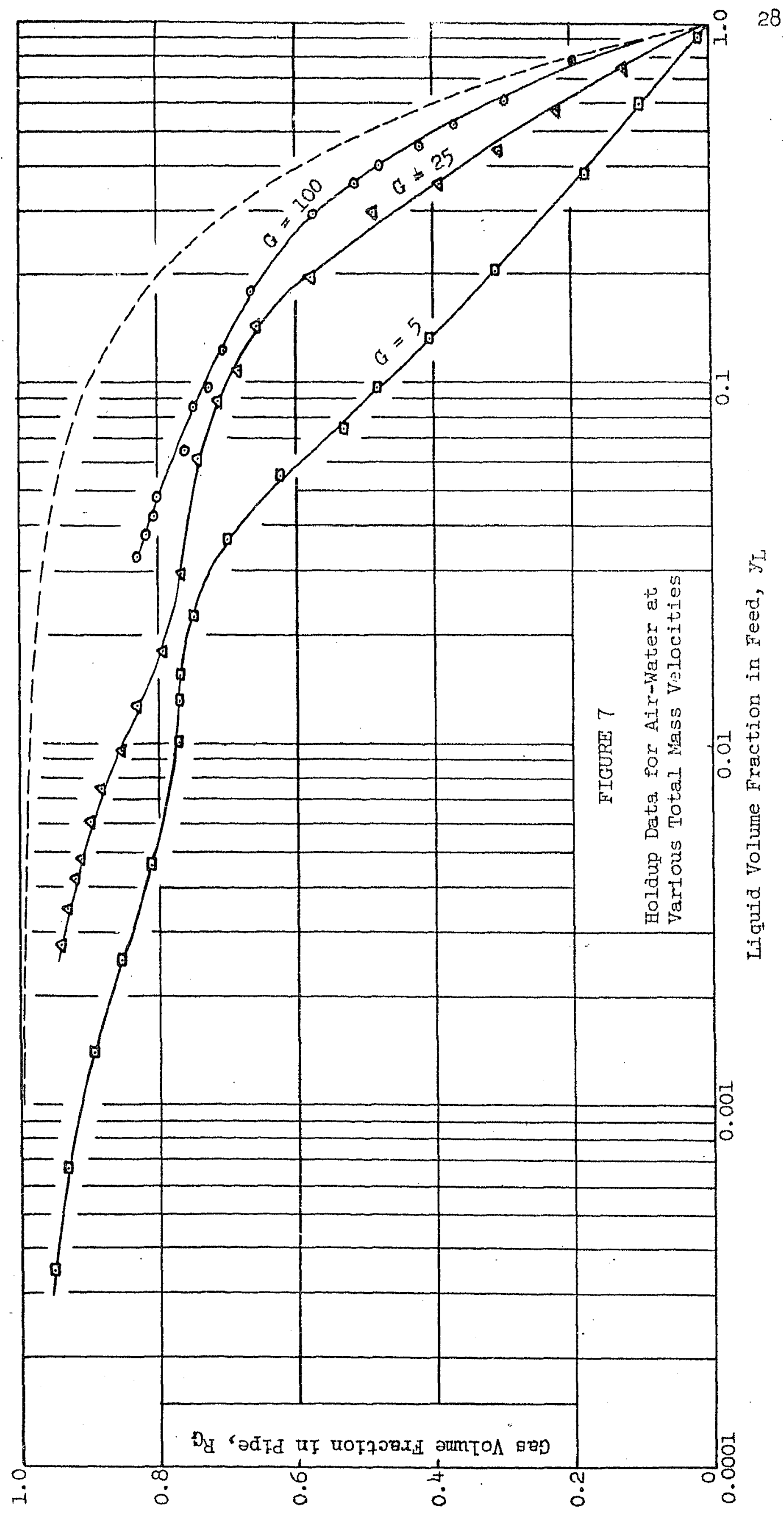

Reproduced with permission of the copyright owner. Further reproduction prohibited without permission. 
Figures 6 and 7 represent only a small part of the experimental data. However, the observations for other flow rates are consistent with Figure 6 and those for other fluids are consistent with Figure 7 . In summary, the difference between $R_{G}$ and $y_{G}$ is indicated to behave qualitatively as follows:

1. $R_{G}=y_{G}$ at $y_{L}=1$. As $y_{L}$ decreases, the difference between $R_{G}$ and $y_{G}$ increases to a maximum and then decreases to 0 at $\mathrm{y}_{\mathrm{L}}=0$.

2. Since $R_{G}$ is always less than $y_{G}$, the gas velocity is always greater than the liquid velocity.

3. At constant $y_{L}$, the difference between $R_{G}$ and $y_{G}$ tends to be greater at low total mass velocities than at high total mass velocities:

4. At constant $y_{I}$ and constant total mass velocity, the difference between $R_{G}$ and $y_{G}$ appears to increase with increasing. liquid viscosity and with increasing surface tension.

Holdup Data Correlation

Figure 8 shows experimental data for the air-water system at total mass velocities of 5,25 , and $150 \mathrm{lb} / \mathrm{sq}$ ft sec. presented in the form used by Lockhart and Martinelli. ${ }^{15}$ From the relative consistency of the data for each flow rate and their position relative to the best line drawn for the Lockhart-Martinelli data, it is apparent that mass velocity is an important variable that is not included in their correlation.

The experimental data appear to be substantially parallel to the best line Lockhart-Martinelli correlation and the deviations appear to be a function of total mass velocity. The correlating factor used by Lockhart and Martinelli and shown by equation (1) was 


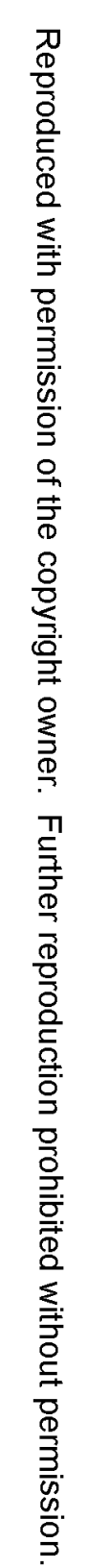

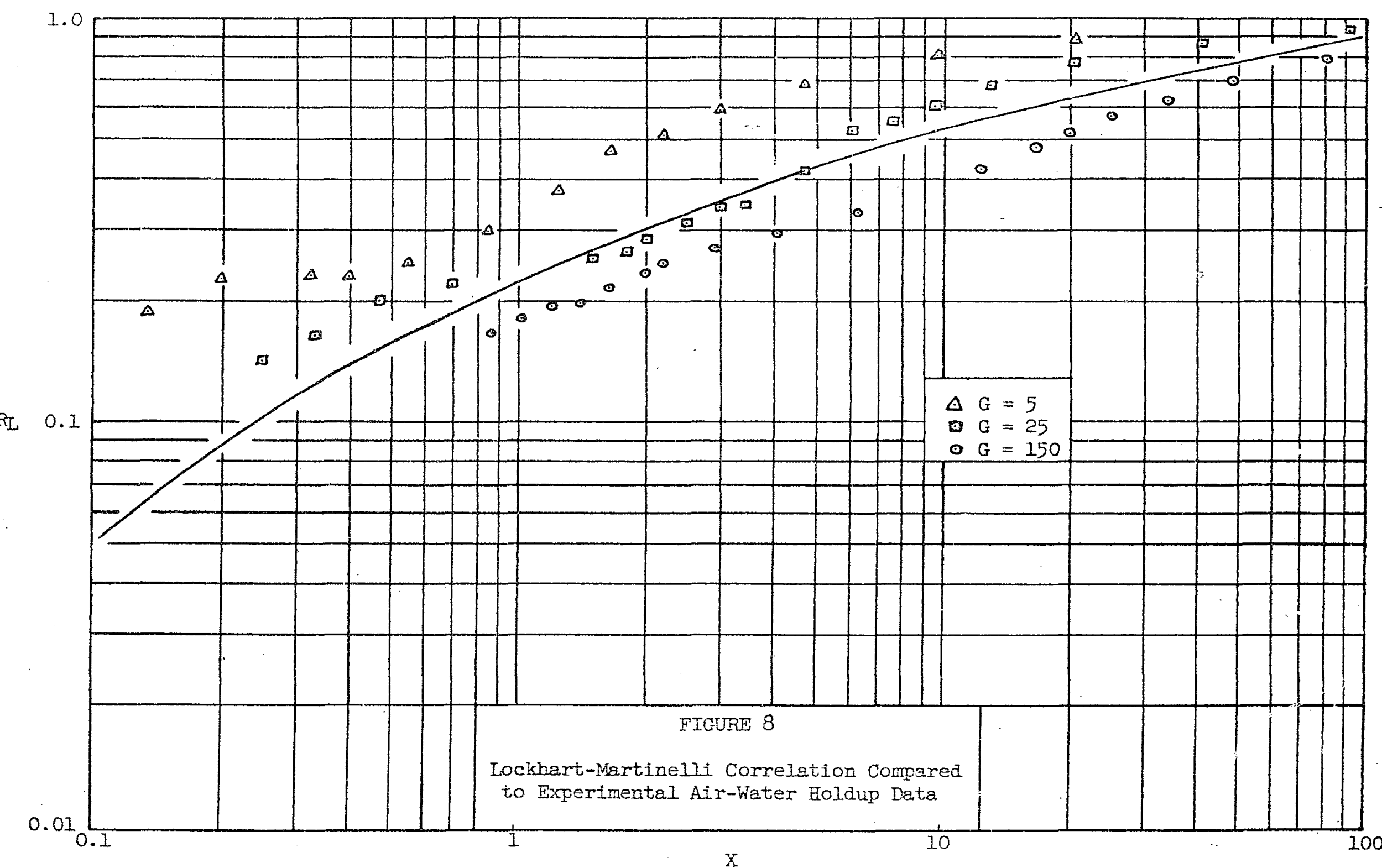




$$
X=\left(\frac{W_{L}}{W_{G}}\right)^{0.9}\left(\frac{\rho_{G}}{\rho_{L}}\right)^{0.5}\left(\frac{\mu_{L}}{\mu_{G}}\right)^{0.1}
$$

The viscosity term is corstant for each liquid tested in this investigation. Therefore, $\left(\frac{W_{L}}{W_{G}}\right)^{0.9}\left(\frac{\rho G}{\rho L}\right)^{0.5}$ was used as the initial correlating factor. This was plotted versus $R_{L}$ with a separate plot for each liquid. Figure 9 shows the plot for the air-water data. The plots for the other liquids were similar. Data for total mass velocities of 50,100 and 150 were found to fall together. The function $\frac{1}{\mathrm{G}^{0.435}}$ was found to correlate the parameters for total mass velocities of $5,10,25$ and 50 . A separate pilot was then made for each liquid of $R_{L}$ versus $\frac{1}{G^{0.435}}\left(\frac{W_{L}}{W_{G}}\right)^{0.9}\left(\frac{\rho G}{\rho L}\right)^{0.5}$. When $G$ was greater than 50, a value of 50 was used. A best line was drawn for each plot and these lines were then drawn on a single plot shown by Figure 10 .

The parameters are essentially parallel for the liquids. At $\mathrm{R}_{\mathrm{L}}=$ .60 , the value of $\frac{1}{G^{0.435}}\left(\frac{W_{L}}{W_{G}}\right)^{0.9}\left(\frac{\rho_{G}}{\rho_{L}}\right)^{0.5}$ was obtained for each liquid. This was divided by $\left(\frac{\rho_{G}}{\rho_{L}}\right)^{0.5}$ at the average conditions of the runs to eliminate density from the terms and thus obtain the best value of $\frac{1}{G^{0.435}}\left(\frac{W_{L}}{W_{G}}\right)^{0.9}$ for each liquid. This value was correlated by the equation:

$$
\begin{aligned}
\log & {\left[\frac{1}{G^{0.435}}\left(\frac{W_{L}}{W_{G}}\right)^{0.9}\right]=\log a_{O}+a_{1} \log \rho_{L}+a_{2} \log \mu_{L} } \\
& +a_{3} \log \sigma
\end{aligned}
$$

A least squares calculation was made with the LGP-30 computer at the Ethyl Corporation to obtain the best fit to the equation. The correlation coefficient for the least squares fit was 0.98 which indicates a high level. of significance of the fit of the equation to the data. The data obtained are shown by Table $V$. 


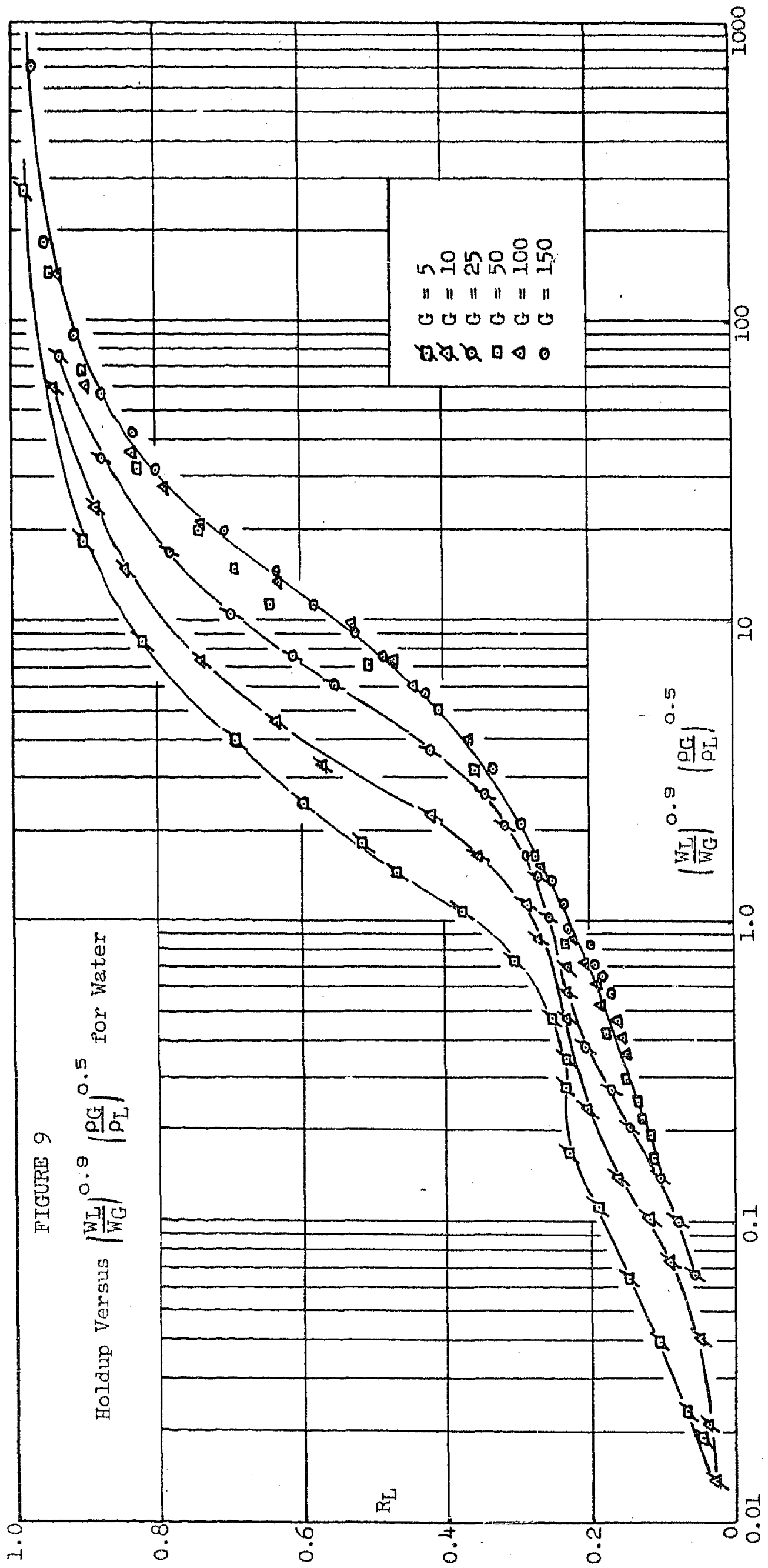




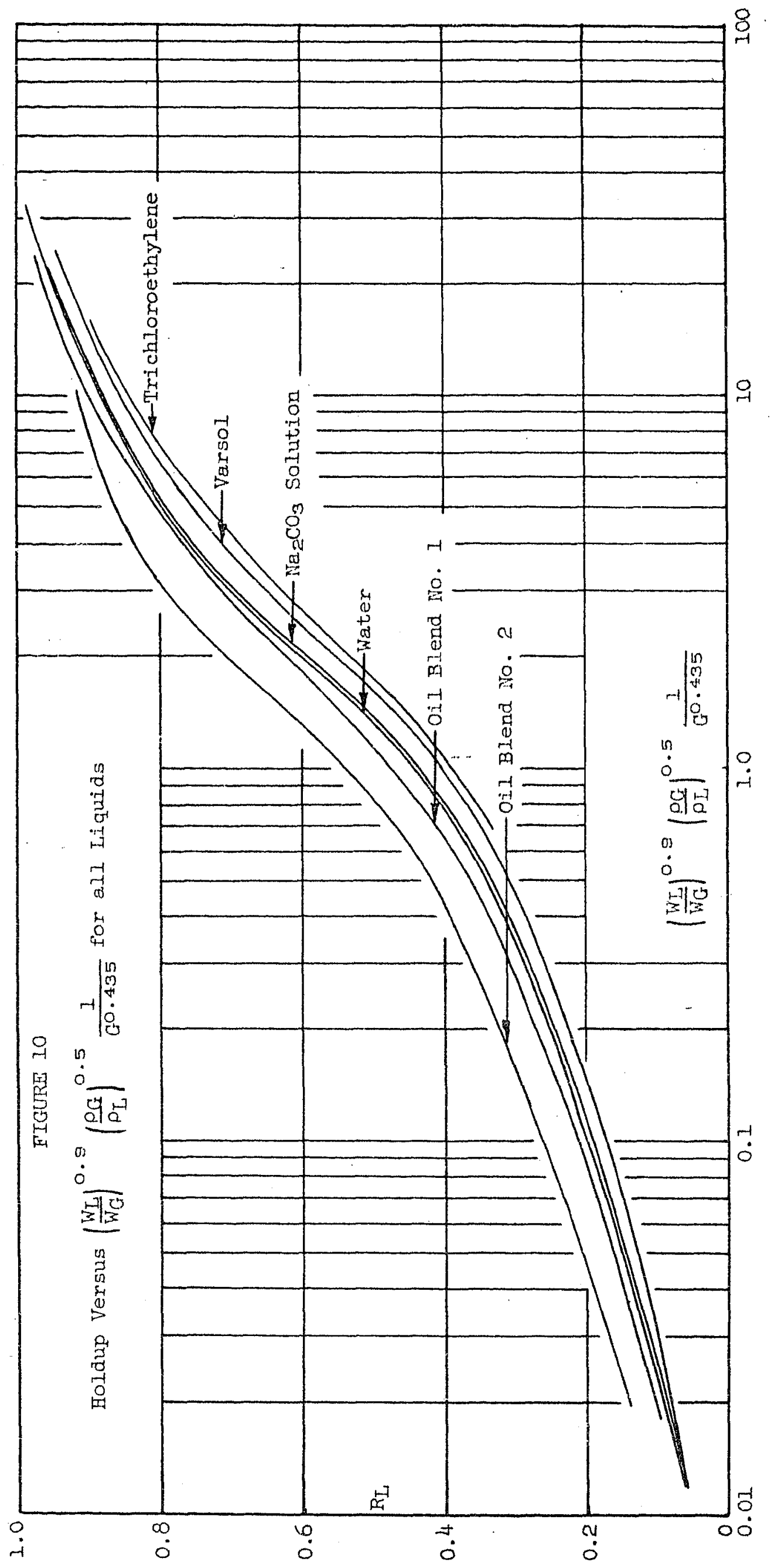




\section{TABLE V}

Summary of Coefficients and Standard Deviations

for Holdup Correlation - Experimental Data

$\underline{\text { Physical Property }}$

$\rho_{\mathrm{L}}$
$\mu_{\mathrm{L}}$

\section{Coefficient}

$$
-0.70989
$$

$+0.18971$

$+0.20448$ $\underline{\text { Standard Deviation }}$

$$
\begin{aligned}
& 0.265 \\
& 0.040 \\
& 0.106
\end{aligned}
$$

The coefficients are twice the standard deviation or higher. All three coefficients are therefore at the $95 \%$ confidence level or better.

Correlation of the experimental data did not consider either density or viscosity of the gas phase because these did not vary significantly. The data of Schwarz ${ }^{22}$ report holdup data on water-steam at 20 to 80 atmospheres pressure. These data were worked up in the same manner as the experimental data and were pooled with the experimental data for correlation to obtain coefficients for $\rho_{G}$ and $\mu_{G^{\circ}}$. The results are shown by Table VI.

\section{TABLE VI}

Summary of Coefficients and Standard Deviations for Holdup Correlation Schwarz Data and Experimental Data

\section{Physical Property}

$\rho_{L}$
$\mu_{L}$
$\sigma$
$\rho_{G}$
$\mu_{G}$

\section{Coefficient}

$-0.7205$

$+0.18773$

$+0.2054$

$+0.70266$

$+2.7539$
Standard Deviation

0.22

0.032

0.09

0.10

0.56

The coefficients for the liquid physical properties are essentially the same as for the correlation of the experimental data alone. All coefficients are above the $98 \%$ confidence level. The correlation coefficient was 0.99 .

The correlating function for $R_{I}$ is thus found to be 


$$
\left(\frac{W L}{W G}\right)^{0.9} \frac{\mu_{I}^{0.19} \sigma^{0.205} \rho_{G}^{0.70} \mu_{G}^{2.75}}{G^{0.435} \rho_{L}^{0.72}}
$$

where $\mathrm{G}$ is a maximum of $50 \mathrm{lb} / \mathrm{sq} \mathrm{ft}$ sec. The experimental data were correlated using this function but neglecting $\mu_{G}$ which was constant at 0.018 centipoises. The calculated function $\mathrm{x}$ and $\mathrm{R}_{\mathrm{L}}$ are tabulated in Appendix $\mathrm{C}$ for all of the experimental data. The correlated data are shown by Figure ll. Gas viscosity is then added to the function by the factor

$$
\left(\frac{\mu_{G}}{0.018}\right)^{2.75}=6 \times 10^{4} \mu_{G}^{2.75}
$$

The final correlation shown by Figure 12 plots $R_{L}$ against the function $x$.

$$
\begin{aligned}
& x=6 \times 10^{4}\left(\frac{W_{L}}{W_{G}}\right)^{0.9} \frac{\mu_{L}^{0.19} \sigma^{0.205} \rho_{G}^{0.70} \mu_{G}{ }^{2.75}}{G^{0.435} \rho_{L}^{0.72}} \cdots \text { (10) } \\
& \mathrm{W}=\text { weight rate of flow, } \mathrm{lb} / \mathrm{sec} \text {. } \\
& \mu=\text { viscosity, centipoises } \\
& \rho=\text { density, } \mathrm{lb} / \mathrm{cu} \mathrm{ft} \\
& G=\text { total mass velocity, } 1 \mathrm{~b} / \mathrm{sq} \text { ft } \mathrm{sec} \text {. All values greater than } \\
& 50 \text { are assumed to equal } 50 . \\
& \sigma=\text { surface tension, dynes } / \mathrm{cm} \text {. }
\end{aligned}
$$

data by determining $\mathrm{R}_{\mathrm{L}}$ (observed)- $\mathrm{R}_{\mathrm{L}}$ (calculated). The correlation was also compared in the same way with published holdup data. The results are tabulated by Table VII.

Excellent agreement is obtained with the proposed correlation over a wide range of fluid physical properties and for pipe diameters from C. 4 to 2.34 inches in diameter. 


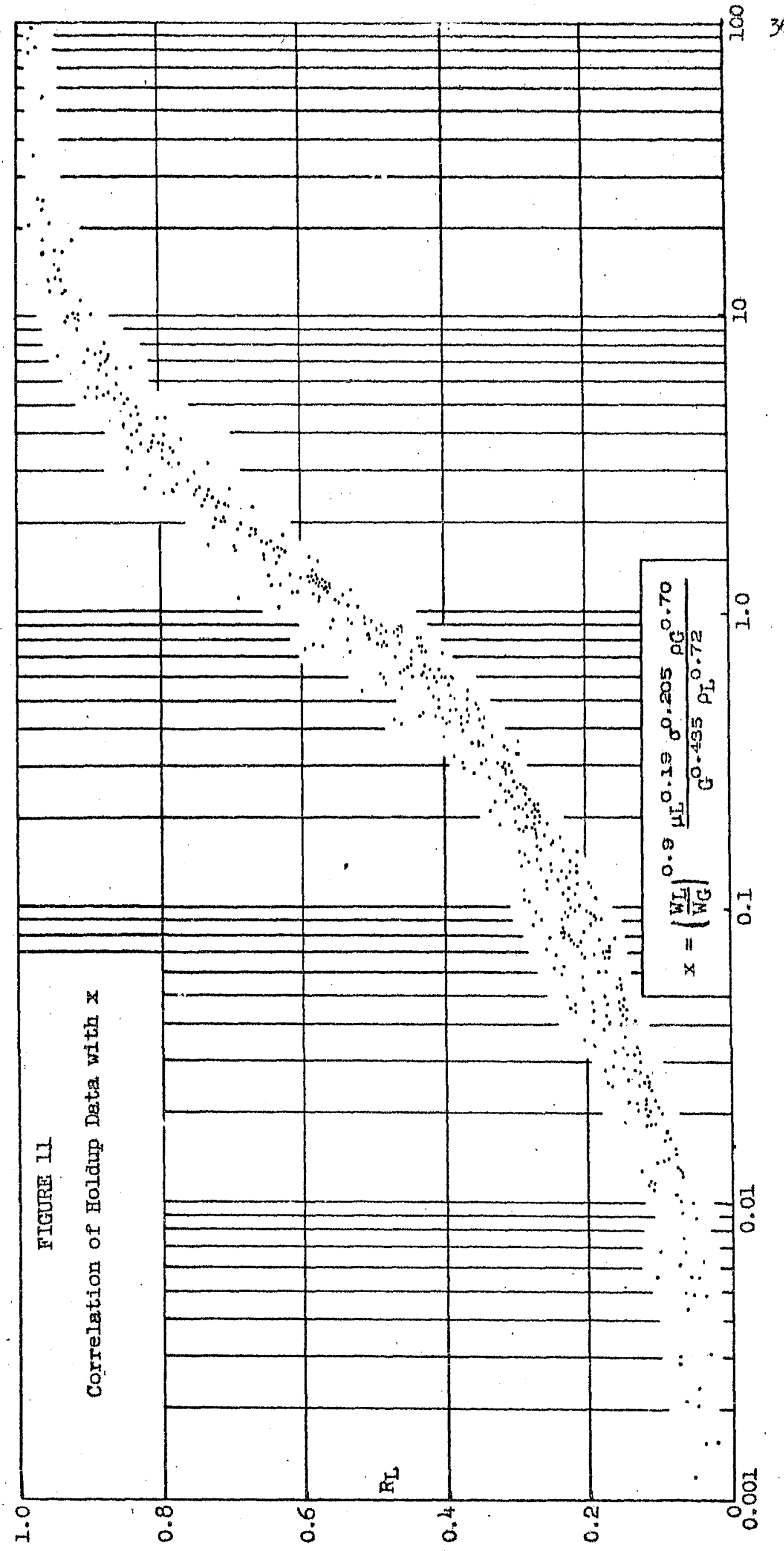

Reproduced with permission of the copyright owner. Further reproduction prohibited without permission. 


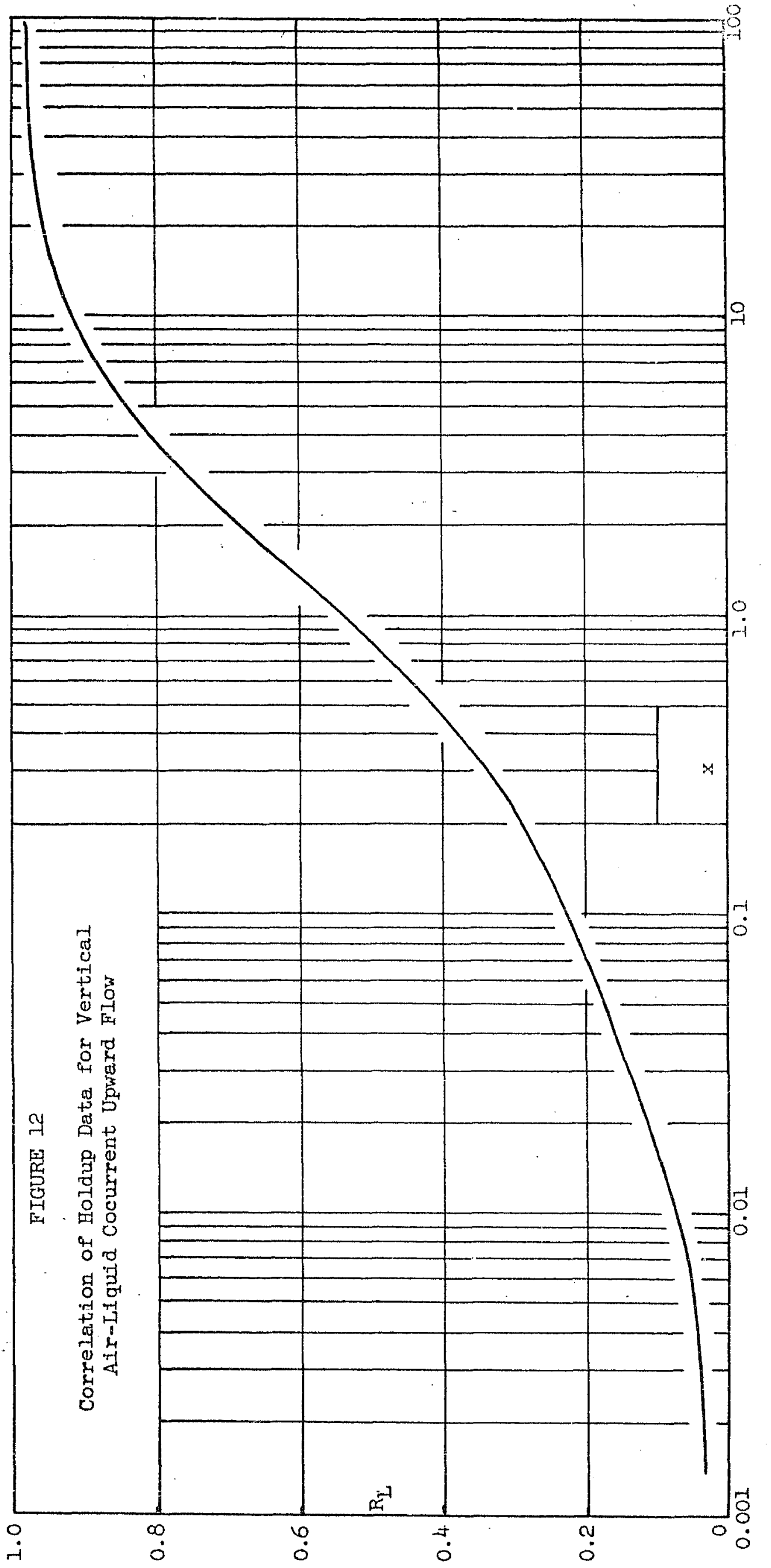




\section{TABIF VII}

Summary of $R_{\mathrm{L}}$ (Observed)- $\mathrm{R}_{\mathrm{L}}$ (Calculated)

for Proposed Holdup Correlation

\begin{tabular}{|c|c|}
\hline Investigator & System \\
\hline This investigation & Air-Water \\
\hline This investigation & Air- $\mathrm{Na}_{2} \mathrm{CO}_{3}$ Solution \\
\hline This investigation & Air-Varsol \\
\hline This investigation & Air-Oil Blend No. 1 \\
\hline This investigation & Air-Oil Blend No. 2 \\
\hline This investigation & Air-Trichloroethylene \\
\hline Govier et al. ${ }^{11}$ & Air-Water. \\
\hline Yagi et al. 24 & Air-Water \\
\hline Yagi et al.25 & Air-Water \\
\hline Schurig 21 & Air-Water \\
\hline Isbin et al. 12 & Steam-Water \\
\hline Schwarz ${ }^{22}$ & Steam-water \\
\hline Galegar et a.1.10 & Air-Water \\
\hline Galegar et al. 10 & Air-Water \\
\hline
\end{tabular}

\begin{tabular}{|c|c|c|c|}
\hline $\begin{array}{l}\text { Pipe Diameter } \\
\text { Inches } \\
\end{array}$ & $\begin{array}{l}\text { No. of } \\
\text { Runs } \\
\end{array}$ & $\begin{array}{c}\text { Average } \\
\triangle R_{\text {L }} \\
\end{array}$ & Range of $\triangle R_{\mathrm{L}}$ \\
\hline 1.049 & 176 & 0.0221 & -0.11 to +0.038 \\
\hline 1.049 & 108 & 0.0228 & -0.074 to +0.065 \\
\hline 1.049 & 97 & 0.0225 & -0.067 to +0.052 \\
\hline 1.049 & 90 & 0.021 & -0.057 to +0.06 \\
\hline 1.049 & 55 & 0.0239 & -0.033 to +0.064 \\
\hline 1.049 & 25 & 0.0218 & -0.038 to to. 053 \\
\hline 1.025 & 26 & 0.024 & -0.058 to +0.023 \\
\hline 0.405 & 24 & 0.014 & -0.04 to +0.028 \\
\hline 0.69 & 16 & 0.012 & -0.03 to +0.02 \\
\hline 1.85 & 29 & 0.0455 & -0.105 to +0.032 \\
\hline 0.872 & 23 & 0.073 & -0.18 to +0.02 \\
\hline 2.34 & 15 & 0.025 & -0.078 to +0.025 \\
\hline 2.0 & 32 & 0.0445 & -0.14 to +0.027 \\
\hline 0.52 & 15 & 0.045 & -0.075 to -0.015 \\
\hline
\end{tabular}


Two-Phase Pressure Drop

The term $\frac{W_{L}\left(V_{L_{2}}{ }^{2}-V_{L_{I}}^{2}\right)+W_{G}\left(V_{G_{2}}^{2}-V_{G_{I}}^{2}\right)}{2 g_{c}\left(W_{L} v_{L}+W_{G} v_{G a m}\right)}$ of equation (7) was found

to be negligible for the experimental data. Equation (7) then reduces to

$$
\frac{\left(Z_{2}-Z_{1}\right)\left(W_{L}+W_{G}\right)}{\left(W_{L} v_{L}+W_{G} v_{G m}\right)}-\left(p_{1}-p_{2}\right)+\Delta P_{T P}=0 \ldots-. .-(11)
$$

Equation (11) was used to calculate $\triangle \mathrm{P}_{\mathrm{TP}}$ from the experimental data. The first term, the pressure change due to potential head, was calculated based on the air and liquid rates entering the pipe. The differential pressure $\left(p_{1}-p_{2}\right)$ was that measured between the two pressure taps.

Figure 13 and Figure 14 show the results, using the methods proposed by Lockhart and Martinelli ${ }^{15}$ and Chenoweth and Martin ${ }^{6}$ to correlate the experimental data in the turbulent range for the air-water system. A definite trend with mass velocity is shown in each case.

The two-phase pressure drop, $\Delta \mathrm{PTP}_{\mathrm{TP}}$, is due to two mechanisms both of which cause energy losses,

1. Friction between the fluid and the pipe wall.

2. Turbulence between the two phases.

The latter of these could be expected to be a function of the difference in velocity between the two phases which is derined as the slip velocity. Figure 15 shows the two-phase pressure drop per foot of pipe versus slip velocity for the air-water runs. Similar plots were obtained with the data for the other fluids studied. Calculated slip velocity and two-phase pressure drop per unit length for the experimental runs are tabulated in Appendix C. Figure 16 shows $\Delta \mathrm{P}_{\mathrm{TP}} / \mathrm{L}$ versus slip velocity for all systems for tests made at a total mass velocity of $150 \mathrm{lb} / \mathrm{sq} \mathrm{ft} \mathrm{sec}$.

The ordinate intercept is the pressure drop for $100 \%$ liquid Ilow. To force all series to pass through zero $\Delta \mathrm{PTP} / \mathrm{L}$ at zero slip velocity, the ordinate was revised to $\frac{\Delta P_{T P}-\Delta P_{L}}{L}$ where $\Delta P_{\mathrm{I}}$ is the pressure drop for liquid flow at the total mass velocity of the specific series of 


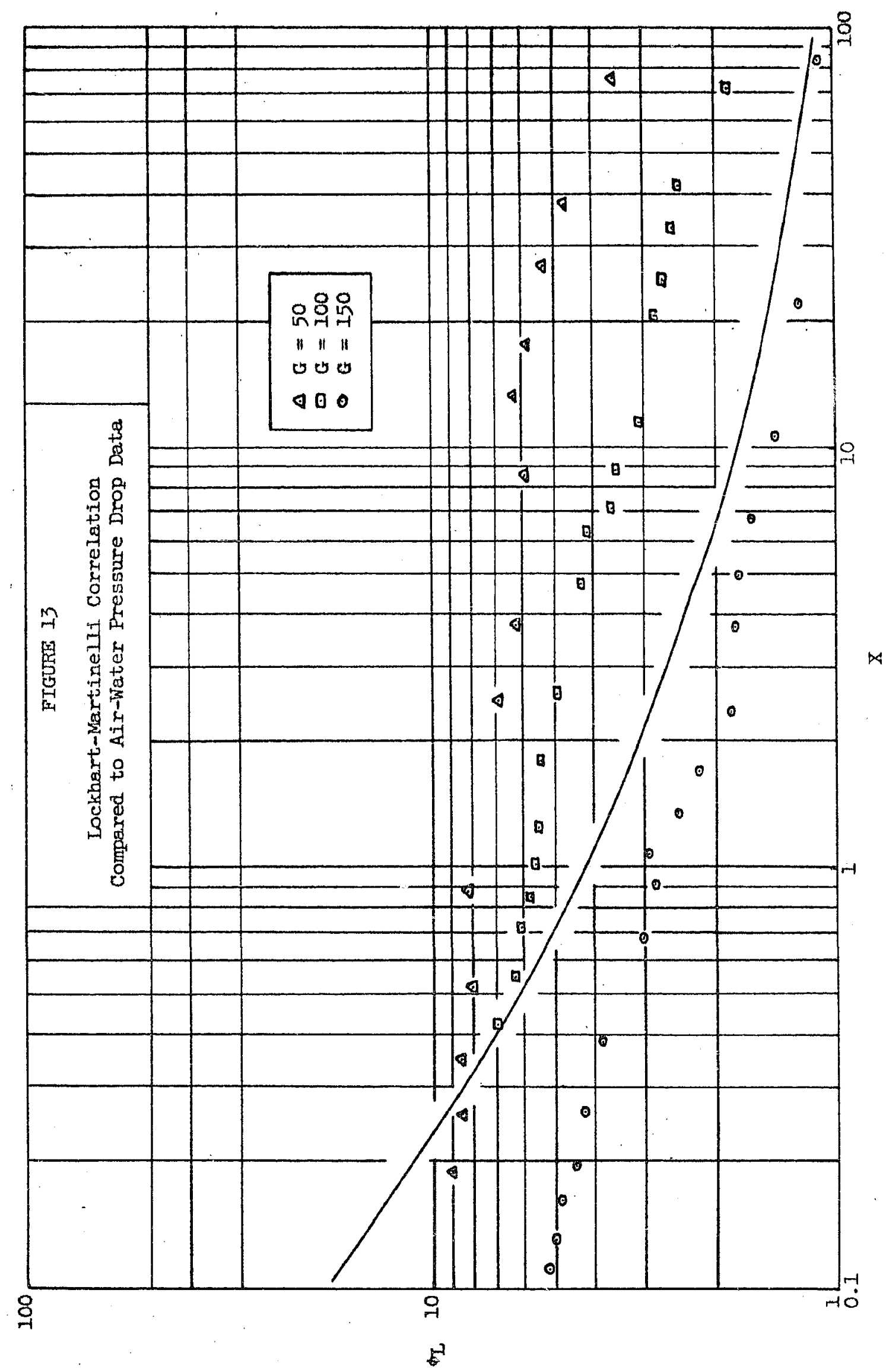




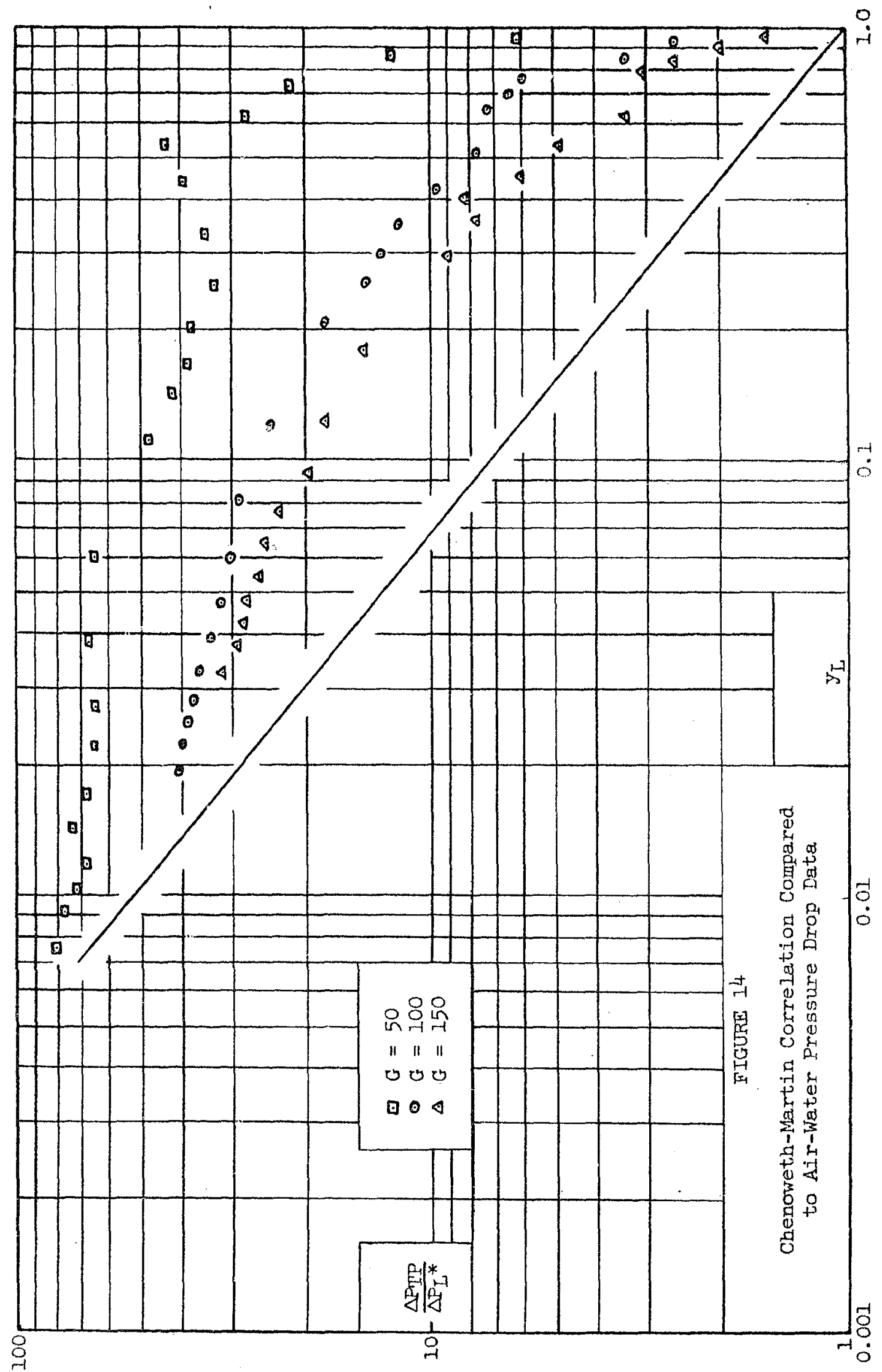




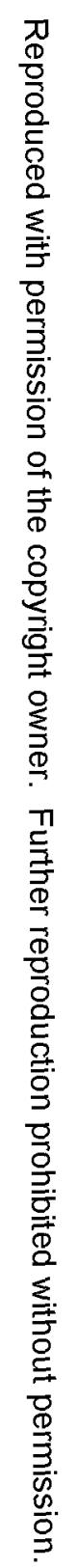

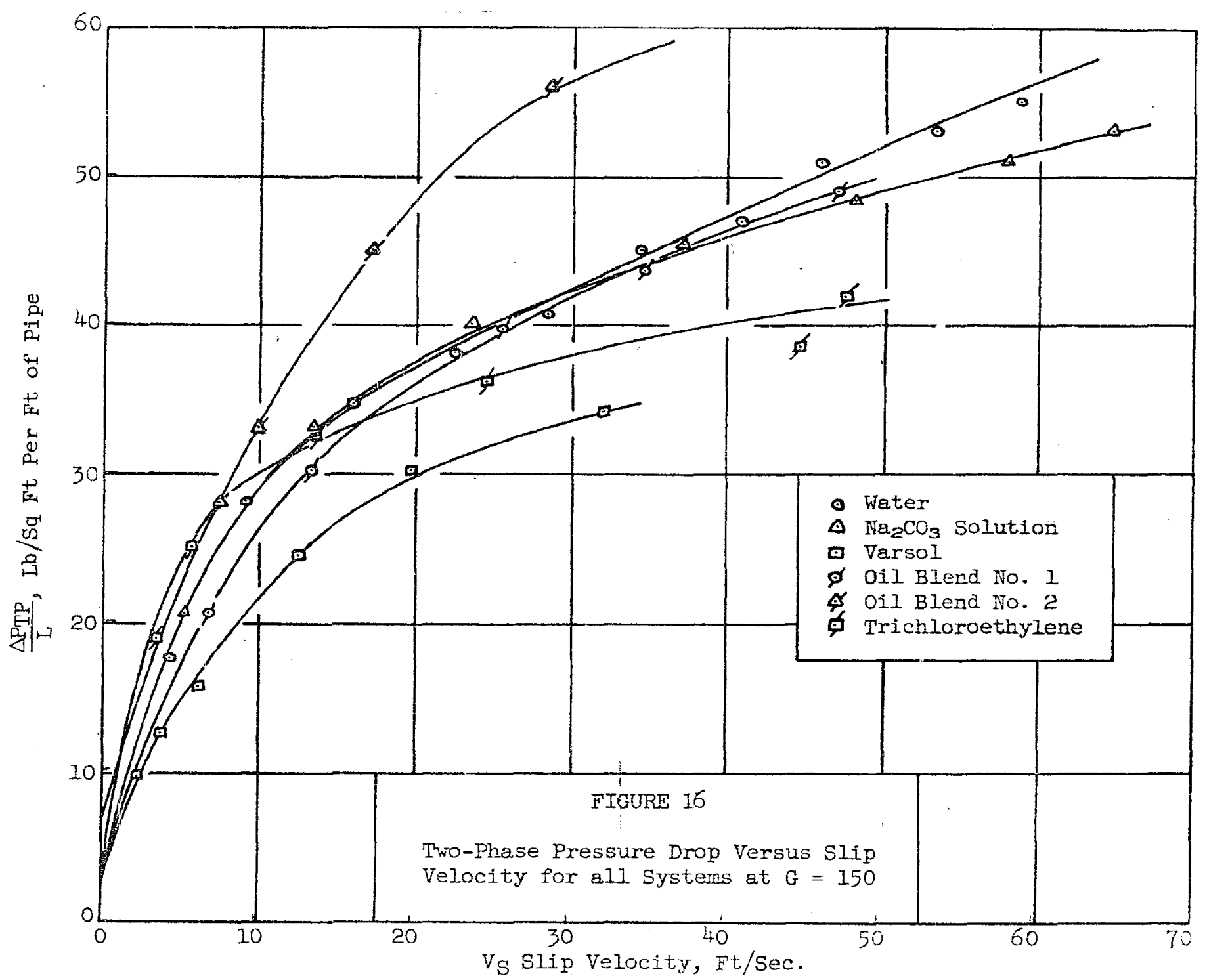


runs. The data were replotted and at a slip velocity of $40 \mathrm{ft} / \mathrm{sec}$, a value of $\frac{\triangle P r P-\triangle P L}{L}$ was obtained for each system at each total mass velocity. These values were correlated by the equation:

$$
\begin{aligned}
\log \frac{\Delta P_{T P}-\Delta P_{I}}{L}=\log a_{0}+a_{1} \log \rho_{L}+a_{2} \log \mu_{L}+a_{3} \log \sigma \\
\left.\quad+a_{4} \log G \ldots \ldots-\ldots-\ldots-\ldots\right)
\end{aligned}
$$

The computer was used to obtain the best least squares fit in the same manner as for the holdup correlation. A correlation coefficient of 0.984 was obtained with $a_{1}=0$. This indicates that the correlation is independent of liquid density. The data are shown by Table VIII.

\section{TABLE VIII}

Summary of Coefficients and Standard Deviationi for Pressure Drop Correlation

Physical Property

$$
\begin{aligned}
& \mu_{L} \\
& \sigma \\
& G
\end{aligned}
$$

Coefficient

$$
-0.1476
$$$$
-0.1944
$$

$-0.6973$
Standard Deviation

$$
0.019
$$

0.033

The coefficients are at least three times the standard deviation which indicates that each is very significant. The parameter to correlate physical properties and total mass velocity is therefore

$$
\psi=\frac{1}{\mu_{\mathrm{L}}^{0.149} \sigma^{0.194} G^{0.70}} \ldots \ldots . . . . . . . .(13)
$$

Plots were then made of $\frac{\triangle P T P-\triangle P L}{L}$ versus $\psi$ at intervals of slip velocity of $20 \mathrm{ft} / \mathrm{sec}$. Figure 17 shows a typical plot for this step. Best values of $\frac{\Delta \mathrm{P}_{\mathrm{TP}}-\Delta \mathrm{P}_{\mathrm{L}}}{\mathrm{L}}$ were then obtained and plotted with $\psi$ as parameters. The final graph is shown by Figure 18.

Total liquid-gas pressure drop can then be calculated with equation (1I). The two-phase pressure drop, $\Delta \mathrm{P}_{\mathrm{TP}}$, is calculated by adding $\Delta \mathrm{P}_{\mathrm{L}}$ to $\triangle \mathrm{P}_{\mathrm{TP}}-\triangle \mathrm{P}_{\mathrm{L}}$ obtained from the correlation for a specific fluid and total mass velocity which fixes the value of $\psi$. The proposed correlation procedure was checked with the experimental data by determining the 


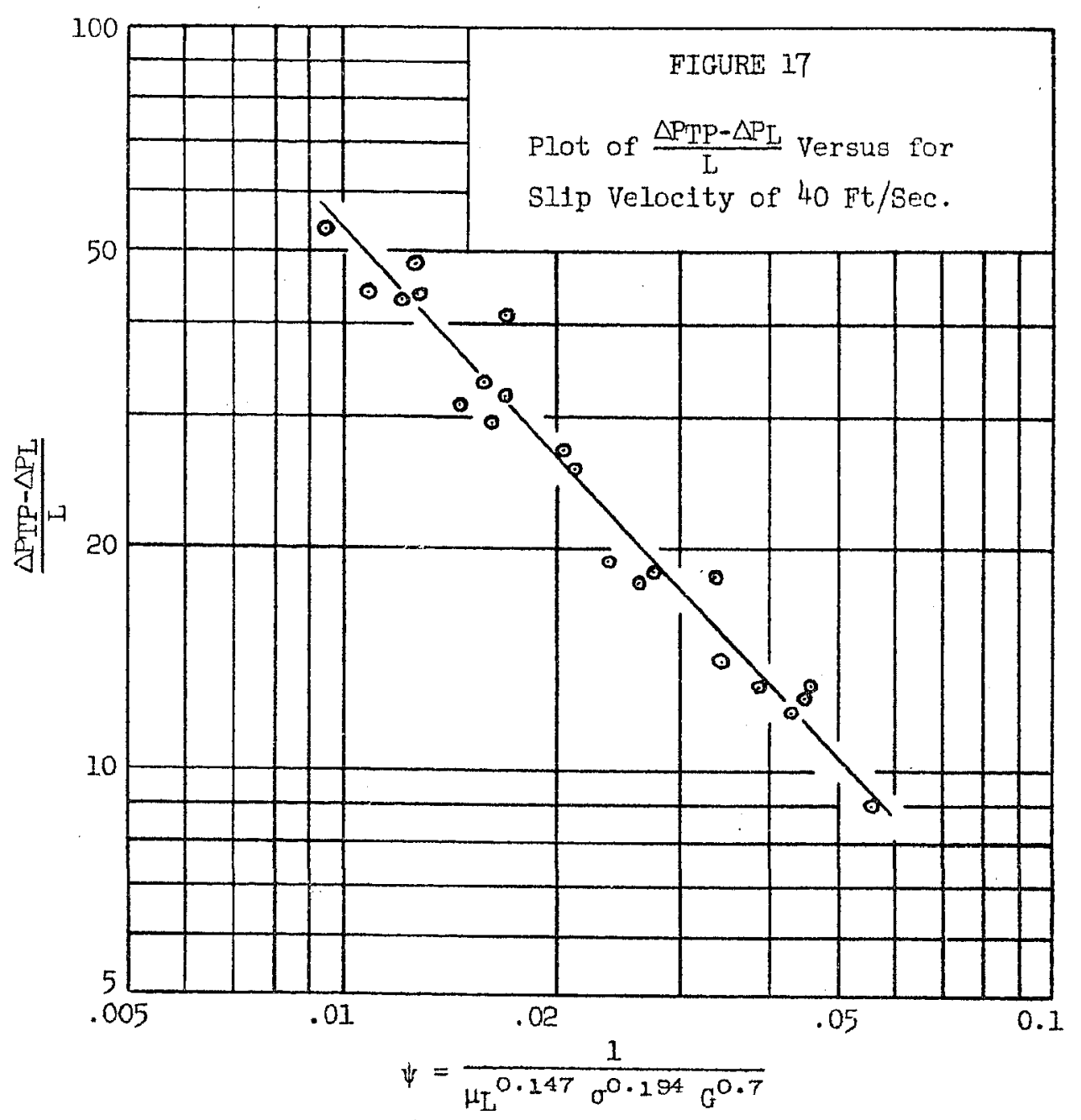




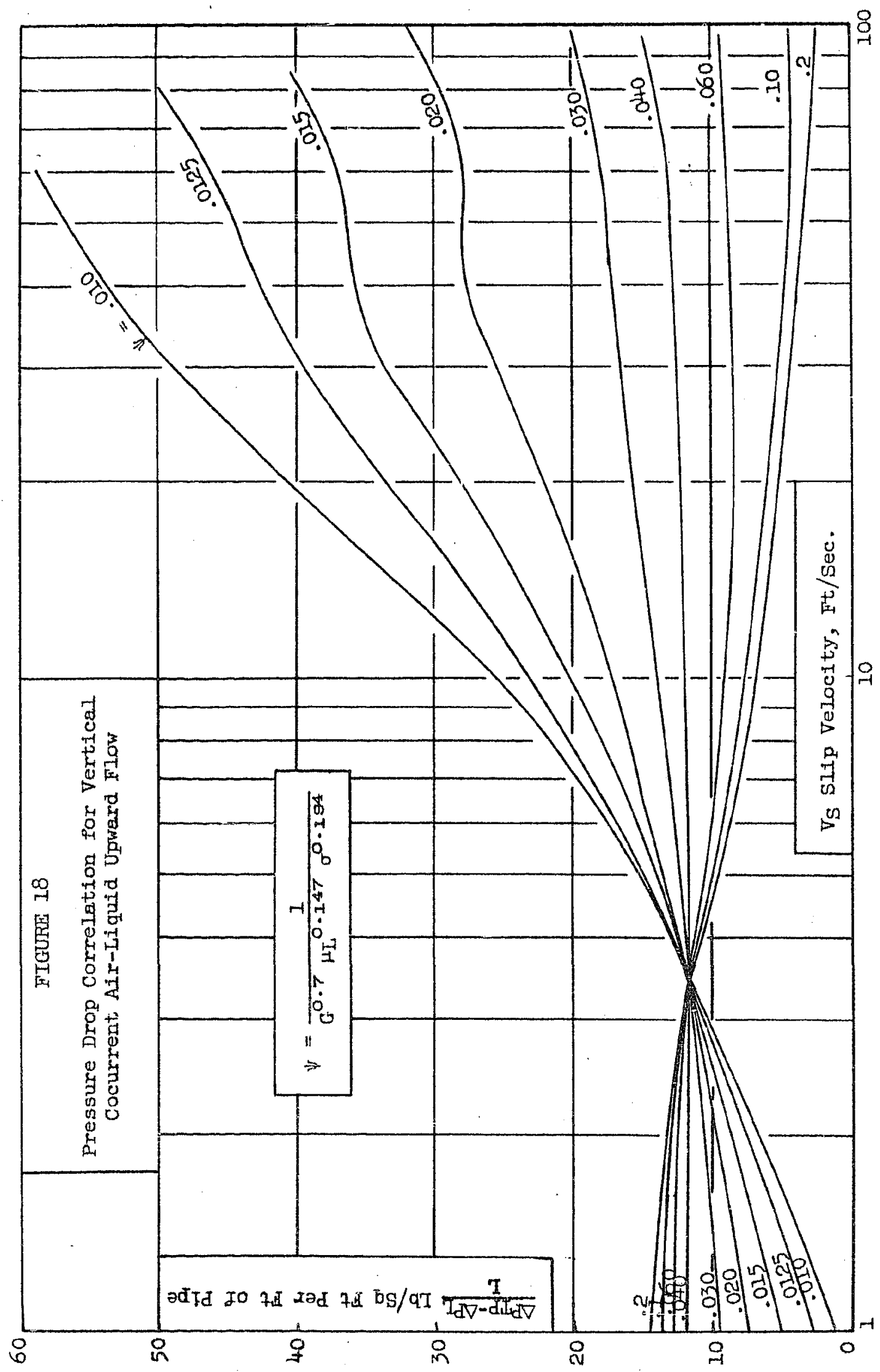


percentage error between the observed and calculated total pressure drop. The results are tabulated in Table IX.

TABLE IX

Comparison of ổserved and Calculated

Total Pressure Drop for Experimental Runs

\begin{tabular}{lcrr}
\multicolumn{1}{c}{ System } & No. of Runs & & Average $\%$ Absolut \\
Air-Water & 182 & 14.2 \\
Air-Nà2CO Solution & 113 & 10.5 \\
Air-Varsol & 96 & 14.3 \\
Air-OiI Blend No. 1 & 90 & 9.2 \\
Air-Oil Blend No. 2 & 57 & 6.4 \\
Air-Trichloroethylene & 25 & 8.4
\end{tabular}

Average Absolute Error of 563 Runs $=11.4 \%$

This correlation is based on a 1.049 inch pipe diameter with a relative roughness of 0.002 . Published data are for smooth pipes of different diameters and were used to extend the correlation.

Galegar et al. ${ }^{10}$ presented pressure drop data for smooth pipes 2 inches and 0.52 inches in diameter. Govier et al. ${ }^{11}$ presented data for a 1.025 inch diameter smooth pipe. These data were correlated with a diameter correction to $\psi$.

$$
\psi=\frac{1}{G^{0.7} \mu_{L}^{0.147} \sigma^{0.194}}\left(\frac{D}{0.0873}\right)^{0.5} \ldots \ldots(14)
$$

where $D$ = inside diameter of pipe, ft.

A correction for pipe roughness was made with a correction to equation (II) to give the following equation for total pressure arop.

$$
\begin{aligned}
\left(p_{1}-p_{2}\right)= & \frac{\left(Z_{2}-Z_{I}\right)\left(W_{L}+W_{G}\right)}{\left(W_{L} V_{I}+W_{G} V_{G m}\right)}+\frac{f_{I}}{f_{L} l_{0.002}} \Delta P_{T P} \\
= & \text { friction factor for liquid at total mass velocity } \\
& \text { in the pipe } \\
\left(f_{I}\right)_{0.00 \varepsilon=} & \text { friction factor for liquid at total mass velocity } \\
& \text { in pipe with relative roughness of } 0.002 .
\end{aligned}
$$


The absolute average percentage error between the observed and calculated data are shown by Table $\mathrm{X}$.

\section{TABLE $X$}

Comparison of Observed and Calculated

Total Pressure Drop for Literature Data

\begin{tabular}{|c|c|c|c|c|}
\hline Investigator & System & $\begin{array}{c}\text { Pipe Diameter, } \\
\text { Inches } \\
\end{array}$ & $\begin{array}{l}\text { No. of } \\
\text { Runs } \\
\end{array}$ & Average \% Error \\
\hline er et al.11 & Air-Water & 1.025 & 27 & 10.4 \\
\hline Galegar et al, 10 & Air-Water & 2.0 & 24 & 14.5 \\
\hline Galegar et al.10 & Air-Water & 0.52 & 15 & 8.3 \\
\hline
\end{tabular}

Thus the correlation for total pressure drop in vertical twophase flow appears to be accurate to within $15 \%$ for the range of dsta investigated. 
Vertical upward cocurrent two-phase flow data were obtained with a one inch pipe for air and six different liquids. The holdup and pressure drop data obtained showed significant deviations from the correlations proposed by Lockhart and Martinelli for horizontal two-phase flow. Therefore, correlations were developed for holdup and pressure drop based on the experimental data,

Gas and liquid physical properties, mass velocity of flow, and mass flows entering the pipe were found to be the important variables for holdup in the pipe. Liquid volume fraction in the pipe was correlated with a function $x$.

$$
\begin{aligned}
& x=\left(\frac{W_{L}}{W_{G}}\right)^{0.9} \frac{\mu_{L}^{0.10} \sigma^{0.205} \rho_{G}^{0.70} \mu_{G}{ }^{0.75}}{G^{0.435} \rho_{L}^{0.72}} \\
& \mathrm{~W}=\text { mass rate entering pipe, } \mathrm{Ib} / \mathrm{sec} \text {. } \\
& G=\text { total mass velocity, } 1 b / s q \text { ft sec. When } G \text { exceeds } 50 \text {, } \\
& \text { a value of } 50 \text { is used. } \\
& \mu \quad=\text { viscosity, centipoises } \\
& \rho \quad=\text { density, } 1 \mathrm{~b} / \mathrm{cu} \text { ft. } \\
& \sigma=\text { surface tension, dynes } / \mathrm{cm} \\
& \text { sub } \mathrm{L}=\text { liquid } \\
& \text { sub } G=\text { gas }
\end{aligned}
$$

The correlation is in close agreement with the experimental data and literature data for holdup. The literature data indicate that holdup is independent of pipe diameter in the range of the available data, 0.4 to 2.34 inches. 
The same variables that effect holdup were found to be important in the correlation of two-phase pressure drop data. This correlation shows two-phase pressure drop to be a function of the difference in velocity between the two phases in the pipe with parameters of $\psi$.

$$
\begin{array}{ll}
\psi=\frac{1}{G^{0.70} \mu_{L}^{0.147} \sigma^{0.194}} \\
G \quad=\text { total mass velocity, lb/sq ft sec. } \\
\mu_{L} \quad=\text { liquid viscosity, centipoises } \\
\sigma \quad=\text { surface tension, dynes } / \mathrm{cm}
\end{array}
$$

Correlation with literature data for 0.5 and 2 inch pipe indicates that $\psi$ is inversely proportional to the square root of the pipe diameter.

The procedure for calculating the total pressure drop for vertical cocurrent upward flow is based on the following equation developed from the Bernoulli thereom.

$$
\begin{aligned}
& \frac{\left(Z_{2}-Z_{1}\right)\left(W_{I}+W_{G}\right)}{\left(W_{L} v_{L}+W_{G} v_{G}\right)}-\left(p_{1}-p_{2}\right)+\Delta P_{T P}=0 \\
& \mathrm{~W}=\text { mass rate entering pipe, } \mathrm{Ib} / \mathrm{sec} \text {. } \\
& \mathrm{Z} \quad=\text { elevation, } \mathrm{ft} \\
& \mathrm{v}=\text { specific volume, cu } \mathrm{ft} / \mathrm{lb} \\
& \mathrm{p} \quad=\text { absolute pressure, Ib/sq ft } \\
& \Delta \mathrm{P}_{\mathrm{TP}} \quad=\text { two-phase pressure drop, } \mathrm{lb} / \mathrm{sq} \mathrm{ft} \\
& \text { sub } I, G=1 \text { iquid, gas } \\
& \text { sub } G_{a m}=\text { arithmetic mean of gas at } 1 \text { and } 2 \\
& \text { sub } I, 2 \text { = inlet and outlet respectively }
\end{aligned}
$$

The procedure is as follows:

1. Calculate the pressure change aue to potential head, the first term of the general equation.

2. Calculate the liquid volume fraction in the pipe with the holdup correlation. 
3. Calculate the liquid and gas velocities in the pipe from the mass flows and 2 .

4. Calculate $\triangle P_{T P}$ from the difference in velocity between the two-phases from 3 and for $\psi$ for the system.

5. With the head term and $\triangle P_{T P}$ thus obtained, calculate $\left(p_{1}-p_{2}\right)$ from the general equation.

Recommendations for extending this work are as follows:

1. The holdup correlation is based upon only two gases: air and steam. Additional data should be obtained with other gases to better determine the effect of gas physical properties.

2. The pressure drop correlation is based on air as the gas with experimental data for pressures near atmospheric. The correlation could be extended with work on other gases to determine the effect of gas physical properties and at higher pressures to determine the effect of pressure. 
NOMENCLATURE

\begin{tabular}{|c|c|}
\hline$a_{0}$ & constant \\
\hline$a_{1}, a_{2}, a_{3}, a_{4}$ & exponents \\
\hline D & inside diameter of pipe, ft \\
\hline F & energy loss to friction, ft-lb force/lb-mass \\
\hline f & friction factor \\
\hline G & mass velocity, 10 mass/sq ft sec. \\
\hline$g_{c}$ & $32.17(1 \mathrm{~b}$ force $)(\mathrm{ft}) /(1 \mathrm{~b}$ mass $)\left(\right.$ sec $\left.^{2}{ }^{2}\right)$ \\
\hline L & length of pipe, ft \\
\hline $\mathrm{N}$ & number of runs in a group \\
\hline$\Delta \mathrm{P}$ & pressure drop, lb force/sq ft \\
\hline $\mathrm{p}$ & absolute pressure, lb force/sq ft \\
\hline $\mathrm{R}$ & volume fraction in pipe \\
\hline V & linear velocity, ft/sec. \\
\hline $\mathrm{v}$ & specific volume, cu ft/lb mass \\
\hline W & mass rate of flow, $1 \mathrm{~b}$ mass/sec. \\
\hline$W_{0}$ & external work, ft-lb force/lb-mass \\
\hline $\mathrm{X}$ & parameter in Lockhart-Martinelli correlation \\
\hline $\mathrm{x}$ & parameter in proposed holdup correlation \\
\hline y & volume fraction entering the pipe \\
\hline Z & elevation, ft \\
\hline$\triangle$ & finite change of variable \\
\hline$\mu$ & viscosity, Ib mass/ft-hr or centipoises as noted \\
\hline$\rho$ & density, Ib mass/cu ft \\
\hline
\end{tabular}




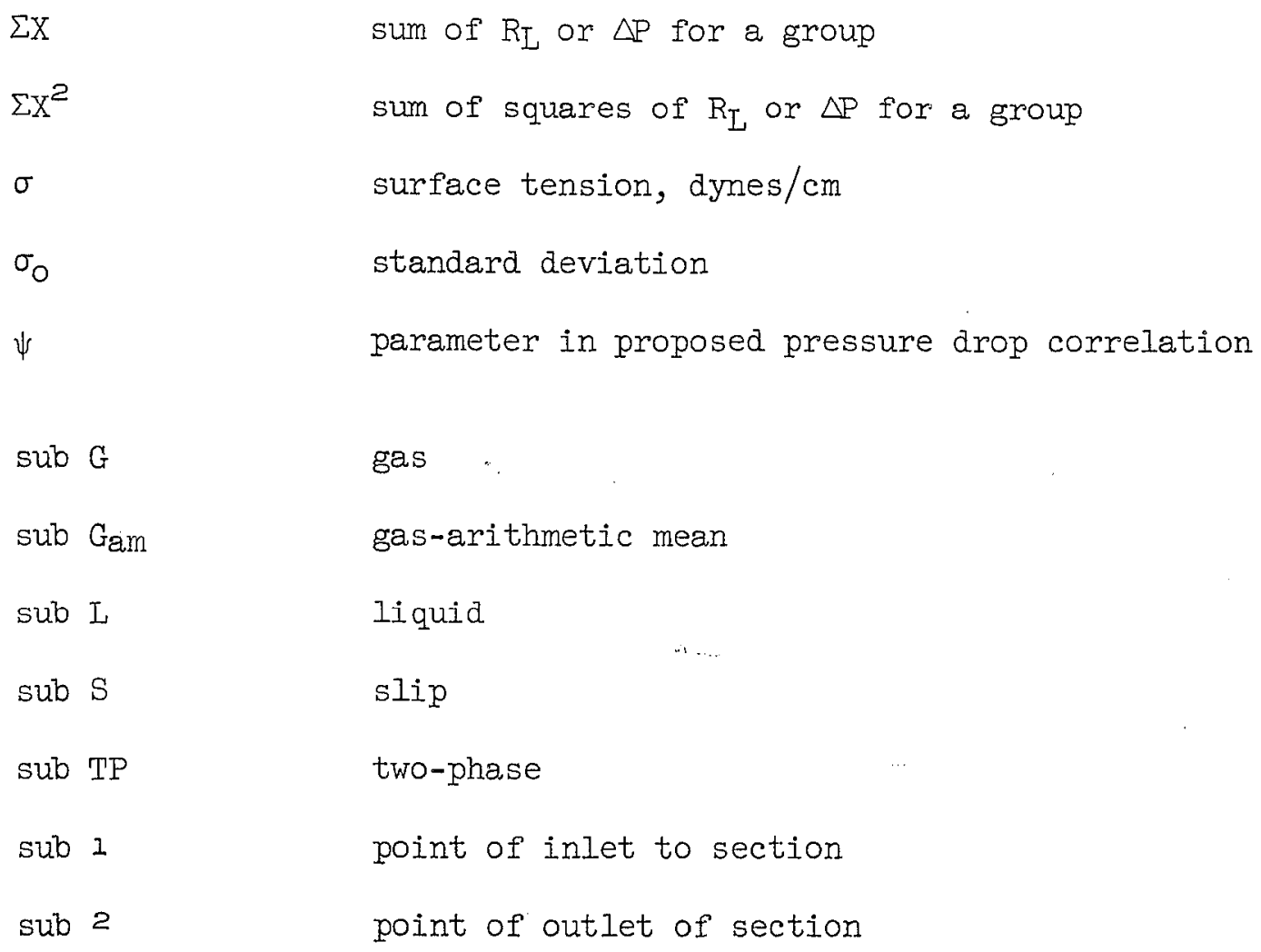




\section{BIBLIOGRAPHY}

(a) Books

1. Gresham, William A. Jr.; Foster, Perry A. Jr.; and Kyle, Robert J. Review of the Literature on Two-Phase (Gas-Liquid) Fluid Flow in Pipes, Part 1。 WADC Technical Report 55-422. Wright Patterson Air Force Base, Ohio: Wright Air Development Center, 1955. Pp. 38-54 +71-106.

2. Hydraulic Institute. Tentative Standards of the Hydraulic Institute, Pipe Friction. New York: Hydraulic Institute, 1947 (Eighth Ēition) Pp. 18, 19.

3. National Research Council. International Critical Tables. New York: McGraw Hill Book Co., 7 1930, (First Edition) 213.

4. Perry, John H. Chemical Engineers' Handbook. New York: MeGraw HiII Book Co., 1950 (Third Edition) Pp。363, 376.

\section{(b) Articles}

5. Calvert, Seymour, Vertical, Upward, Annular, Two-Phase Flow in Smooth Tubes, University of Michigan, Ph.D. Thesis, 1952。

6. Chenoweth, J.M. , and Martin, M.W。 "Turbulent Two-Phase Flow。" Petroleum Refiner, 34 (1955) No. 10, 151-155.

7. Cromer, Sylvan, An Investigation of the Flow of Mixtures of Water and Air in Vertical Columns, University of Oklahoma, M. S. Thesis, 1937.

8. Dukler, Abraham E. An Investigation of Pressure Drop for Isothermal Two-Phase Film Flow in a Vertical Tube, University of Delaware, M. S. Thesis, 1949.

9. Galegar, William C. Simultaneous Fluid Flow of Water and Air in Vertical Tubes, University of Oklahoma, M. S. Thesis, 1953.

10. Galegar, W. C.; Stovall, W. B.; and Huntington, R. I. "More Data on Two-Phase Vertical Flow." Petroleum Refiner, 33 (1954), No. 1I, 208-211.

11. Govier, G. W.; Radford, B.A.; and Dunn, JoS.C. "The Upwards Vertical Flow of Air-Water Mixtures." Canadian Journal of Chemical Engineering, (1957), August, 58-70 
12. Isbin, H. So; Sher, N. Co; and Eddy, K. C. "Void Fractions in TwoPhase Steam-Water Flow." American Institute of Chemical Engi-

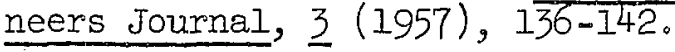

13. Jenkins, Rodman, Two-Phase Two-Component Flow of Water and Air, University of Delaware, M. S. Thesis, 1947.

14. Kege1, Phillip Ko, Two-Phase Flow in a Vertical Column, University of Delaware, B.S.Thesis, 1948.

15. Lockhart, R。W., and Martinelli, R. C. "Proposed Correlation of Data for Isothermal Two-Phase Two-Component Flow in Pipes." Chemical Engineering Progress, 45 (1949) No. 1, 39-48.

16. McElwee, Frank Dixon, Behavior of Two-Phase Two-Component Flow in Tubes, University of California, M。 S。 Thesis, 1949.

17. Martinelli, R。 Co; Boelter, L。M。Ko; Taylor, T. H. Mo; Thomsen, E。 Go; and Morrin, E.H. "Isothermal Pressure Drop for Two-Phase TwoComponent Flow in a Horizontal Pipe." Transactions of the American Society of Mechanical Engineers, 66 (1944) 139-151.

18. Petrick, Michael, Investigation of Two-Phase Air-Water Flow Phenomena, Illinois Institute of Technology, Ph.D. Thesis, 1958.

19. Radford, B. A., Gas-Liquid Flow in Vertical Pipes--A Preliminary Investigation, University of Alberta, Canada, M. S. Thesis, 1949.

20. Reid, R。 C.; Reynolds, A. B。; Diglio, A. J.; Spiewak, I., and Klipstein, D. H. "Two-Phase Pressure Drops in Large-Diameter Pipes." American Institute of Chemical Engineers Journal, 3 (1957) $321-324$.

21. Schurig, Wolfgang, "Wasserumlauf in Dampfkesseln und Bewegung von Flüssigkeitsgasgemi schen in Rohren." VDI - Forshungsheft, 365 (1934) 13-23.

22. Schwarz, Karl "Untersuchung Über die Wichteverteilung, die Wasser und Dampfgeschwendigkeit sowie den Reibungsaruckabfall in Iotrechten und Waagerecten Kesselsteigrohren." VDI - Forshungsheft, 445 (1954) Edition B, I-44。

23. Stovall, William Burroughs, Two-Phase Vertical Flow of Kerosene and Air, University of Oklahoma, Mo S. Thesis, 1953.

24. Yagi, Sakae; Shirai, Takashi; and Sasaki, Teiji, "Vertical Tube Reactor, I. Flow Pattern and Holdup in Gas-Iiquid Two-Phase Flow。" Chemical Engineering (Japan), 15 (1951) 317-322。

25. Yagi, Sakae and Saski, Teiji, "Vertical Tube Reactor, II。 Pressure Drop in Gas-Liquid Two-Phase Flow." Chemical Engineering (Japan), 17 (1953) $216-2 ? 3$. 
APPENDIX A

Holdup and Pressure Drop Data

\begin{tabular}{|c|c|c|c|}
\hline I & $\begin{array}{l}\text { Air Rate } \\
\text { CFM }\end{array}$ & $\begin{array}{c}\text { Water Rate } \\
\text { CFM }\end{array}$ & $\begin{array}{l}\text { Holdup } \\
\text { ce }\end{array}$ \\
\hline
\end{tabular}

Air-Water Runs

$G=5$

$\begin{array}{lllr}135 & 3.02 & 0.0243 & 800 \\ 136 & 4.17 & 0.0227 & 725 \\ 137 & 5.33 & 0.0208 & 620 \\ 138 & 6.45 & 0.0195 & 580 \\ 139 & 7.63 & 0.0179 & 500 \\ 140 & 0.00095 & 0.0289 & 3490 \\ 141 & 0.0195 & 0.0289 & 3185 \\ 142 & 0.0473 & 0.0289 & 2910 \\ 143 & 0.110 & 0.0289 & 2440 \\ 144 & 0.187 & 0.0289 & 2110 \\ 145 & 0.268 & 0.0289 & 1820 \\ 146 & 0.353 & 0.0289 & 1650 \\ 147 & 0.355 & 0.0285 & 1620 \\ 148 & 0.485 & 0.0281 & 1325 \\ 149 & 0.74 & 0.0278 & 1055 \\ 150 & 1.19 & 0.0272 & 875 \\ 151 & 1.70 & 0.0265 & 810 \\ 152 & 1.98 & 0.0262 & 815 \\ 153 & 2.28 & 0.0256 & 800 \\ 194 & 4.73 & 0.0219 & 660 \\ 195 & 7.45 & 0.0187 & 505 \\ 196 & 10.45 & 0.0156 & 350 \\ 197 & 13.4 & 0.011 & 210 \\ 198 & 19.9 & 0.0070 & 125 \\ 199 & 23.2 & 0.0 & 0 \\ & & & \end{array}$

2.8

3.8

725

2.7

3.6

2.5

3.2

580

2.4

3.0

490

2.3

2.7

10.0

9.4

17.6

8.4

16.2

7.0

14.5

6.2

5.3

4.5

4.6

3.7

3.1

2.6

11.45

9.7

8.1

6.8

7.4

5.5

4.25

3.35

2.5

2.6

3.2

2.7

3.4

2.5

3.6

3.1

2.3

2.9

2.0

2.0

2.0

1.5

1.9

1.1

0.9

$G=10$

$\begin{array}{ll}54 & 0.625 \\ 55 & 0.852 \\ 56 & 1.22 \\ 57 & 1.69 \\ 58 & 2.05 \\ 59 & 2.58 \\ 60 & 3.38 \\ 61 & 4.2\end{array}$

$\begin{array}{lr}0.0575 & 1095 \\ 0.0575 & 1045 \\ 0.0575 & 890 \\ 0.0575 & 870 \\ 0.0575 & 815 \\ 0.0575 & 805 \\ 0.0575 & 780 \\ 0.0575 & 790\end{array}$

3.6

4.9

3.0

4.1

3.7

3.6

3.0

3.45

3.5

3.45

2.7

3.7

3.0

4.2

3.1

4.2 
Holdup and Pressure Drop Data

(Continued)

Run No. \begin{tabular}{ccccc}
$\begin{array}{c}\text { Air Rate } \\
\text { CFM }\end{array}$ & $\begin{array}{c}\text { Water Rate } \\
\text { CFM }\end{array}$ & $\begin{array}{c}\text { Holdup } \\
\text { ce }\end{array}$ & $\begin{array}{c}\text { Pressure } \\
\text { Gage, psig }\end{array}$ & $\begin{array}{c}\text { Pressure } \\
\text { Drop, In. Hg }\end{array}$ \\
\hline
\end{tabular}

Air-Water Runs (Continued)

$\begin{array}{rllrrr}78 & 0.00265 & 0.0575 & 3495 & 10.0 & 17.7 \\ 79 & 0.0101 & 0.0575 & 3340 & 9.7 & 16.9 \\ 80 & 0.0288 & 0.0575 & 3150 & 9.2 & 16.4 \\ 81 & 0.047 & 0.0575 & 2990 & 8.7 & 15.0 \\ 82 & 0.109 & 0.0575 & 2610 & 7.4 & 12.6 \\ 83 & 0.186 & 0.0575 & 2240 & 6.5 & 10.5 \\ 84 & 0.264 & 0.0575 & 2015 & 5.7 & 9.0 \\ 85 & 0.343 & 0.0575 & 1730 & 5.1 & 7.9 \\ 187 & 4.75 & 0.051 & 710 & 2.8 & 3.7 \\ 188 & 7.4 & 0.0475 & 550 & 2.5 & 3.2 \\ 189 & 10.5 & 0.0445 & 400 & 2.1 & 2.7 \\ 190 & 13.6 & 0.040 & 300 & 2.0 & 2.1 \\ 191 & 16.5 & 0.036 & 220 & 2.0 & 1.9 \\ 192 & 20.0 & 0.0306 & 150 & 2.0 & 1.7 \\ 193 & 23.6 & 0.0242 & 120 & 2.1 & 1.7 \\ 224 & 0.413 & 0.057 & 1460 & 4.5 & 6.5 \\ 225 & 0.60 & 0.0565 & 1235 & 3.7 & 5.1 \\ 226 & 0.90 & 0.0565 & 1010 & 3.0 & 4.1 \\ 227 & 1.20 & 0.056 & 930 & 2.8 & 3.9 \\ 228 & 1.52 & 0.0555 & 810 & 2.7 & 3.6 \\ 229 & 1.79 & 0.054 & 820 & 2.8 & 3.5 \\ 230 & 2.24 & 0.054 & 810 & 2.8 & 3.7 \\ 278 & 26.4 & 0.020 & 105 & 2.5 & 1.3 \\ 279 & 30.3 & 0.0144 & 80 & 2.4 & 1.2 \\ 280 & 35.5 & 0.0078 & 50 & 2.5 & 1.2 \\ & & & & & \end{array}$

$G=25$

$\begin{array}{rlrrrr}33 & 0.823 & 0.144 & 1225 & 3.8 & 5.5 \\ 34 & 1.66 & 0.144 & 930 & 3.3 & 4.4 \\ 35 & 2.62 & 0.144 & 970 & 3.2 & 4.6 \\ 36 & 3.30 & 0.144 & 890 & 3.5 & 5.1 \\ 37 & 4.12 & 0.144 & 840 & 3.5 & 4.9 \\ 86 & 0.0053 & 0.144 & 3490 & 10.0 & 17.7 \\ 87 & 0.0193 & 0.144 & 3325 & 9.6 & 16.8 \\ 88 & 0.0465 & 0.144 & 3110 & 9.0 & 15.6 \\ 89 & 0.1065 & 0.144 & 2760 & 8.1 & 13.8 \\ 90 & 0.183 & 0.144 & 2450 & 7.1 & 12.0 \\ 91 & 0.26 & 0.144 & 2145 & 6.5 & 10.6 \\ 92 & 0.336 & 0.144 & 1960 & 6.0 & 9.4 \\ 158 & 0.405 & 0.144 & 1820 & 5.5 & 8.9 \\ 180 & 4.55 & 0.138 & 810 & 3.5 & 4.8 \\ 181 & 7.3 & 0.134 & 710 & 3.1 & 4.4 \\ 182 & 10.1 & 0.131 & 575 & 3.0 & 4.0 \\ 183 & 13.0 & 0.127 & 490 & 3.1 & 3.9\end{array}$


Holdup and Pressure Drop Data

(Continued)

\begin{tabular}{|c|c|c|c|c|c|}
\hline Run No. & $\begin{array}{l}\text { Air Rate } \\
\text { CFM } \\
\end{array}$ & $\begin{array}{l}\text { Water Rate } \\
\mathrm{CFM} \\
\end{array}$ & $\begin{array}{l}\text { Holdup } \\
\text { cc } \\
\end{array}$ & $\begin{array}{l}\text { Pressure } \\
\text { Gage, psig } \\
\end{array}$ & $\begin{array}{l}\text { Press } \\
\text { Drop, In } \\
\end{array}$ \\
\hline \multicolumn{6}{|c|}{ Air-Water Runs (Continued) } \\
\hline 184 & 16.0 & 0.122 & 395 & 3.0 & \\
\hline 185 & 19.2 & 0.118 & 335 & 3.1 & \\
\hline 186 & 22.7 & 0.111 & 290 & 3.2 & \\
\hline 218 & 0.595 & 0.144 & 1530 & 4.3 & \\
\hline 219 & 0.87 & 0.244 & 1200 & 3.8 & \\
\hline 220 & 1.18 & 0.144 & 1105 & 3.5 & \\
\hline 221 & 1.50 & 0.144 & 1000 & 3.2 & \\
\hline 222 & 1.83 & 0.144 & 940 & 3.0 & 4. \\
\hline 223 & 2.23 & 0.144 & 900 & 3.4 & 4 \\
\hline 245 & 25.6 & 0.1075 & 260 & 3.6 & \\
\hline 246 & 29.1 & 0.102 & 215 & 3.7 & \\
\hline 247 & 33.9 & 0.0935 & 180 & 4.0 & \\
\hline
\end{tabular}

$G=50$

\begin{tabular}{|c|c|c|c|c|c|}
\hline 27 & 0.791 & 0.289 & 1440 & 5.0 & 7.3 \\
\hline 28 & 1.61 & 0.289 & 1180 & 4.2 & 5.7 \\
\hline 29 & 2.54 & 0.289 & 1070 & 4.0 & 5.7 \\
\hline 30 & 3.14 & 0.289 & 1010 & 4.4 & 5.9 \\
\hline 31 & 3.97 & 0.289 & 975 & 4.4 & 6.0 \\
\hline 47 & 0.796 & 0.289 & 1460 & 5.0 & $7 \cdot 3$ \\
\hline 99 & 0.0054 & 0.289 & 3485 & 10.0 & 17.55 \\
\hline 100 & 0.0191 & 0.289 & 3360 & 9.9 & 17.1 \\
\hline 101 & 0.046 & 0.289 & 3195 & 9.5 & 16.3 \\
\hline 102 & 0.105 & 0.289 & 2930 & 8.7 & 14.7 \\
\hline 103 & 0.178 & 0.289 & 2620 & 8.0 & 13.3 \\
\hline 104 & 0.25 & 0.289 & 2450 & 7.4 & 12.2 \\
\hline 105 & 0.334 & 0.289 & $2270^{\circ}$ & 6.7 & 11.0 \\
\hline 120 & 2.88 & 0.289 & 1060 & 4.2 & 6.3 \\
\hline 121 & 3.95 & 0.289 & 1000 & 4.0 & 6.0 \\
\hline 122 & 5.21 & 0.289 & 910 & 4.0 & 6.0 \\
\hline 123 & 6.35 & 0.289 & 830 & 4.0 & 6.0 \\
\hline 124 & 7.43 & 0.289 & 835 & 4.0 & 5.8 \\
\hline 157 & 0.39 & 0.289 & 2145 & 6.5 & 10.3 \\
\hline 173 & 4.4 & 0.28 & 865 & 4.5 & 6.3 \\
\hline 174 & 7.05 & 0.278 & 810 & 4.1 & 6.0 \\
\hline 175 & 9.8 & 0.275 & 680 & 4.0 & 5.7 \\
\hline 176 & 12.25 & 0.270 & 605 & 4.1 & 5.7 \\
\hline 177 & 15.15 & 0.267 & 550 & 4.5 & 5.8 \\
\hline 178 & 18.2 & 0.261 & 520 & 4.8 & 6.2 \\
\hline 179 & 21.3 & 0.254 & 465 & 4.8 & 5.7 \\
\hline 212 & 0.573 & 0.289 & 1775 & 5.5 & 8.8 \\
\hline 213 & 0.845 & 0.289 & 1420 & 4.8 & 7.3 \\
\hline 214 & 1.14 & 0.289 & 1265 & 4.6 & 6.7 \\
\hline 215 & 1.43 & $0.289 \ldots$ & 1260 & 4.2 & 6.1 \\
\hline
\end{tabular}


Holdup and Pressure Drop Data

(Continued)

\begin{tabular}{|c|c|c|c|c|c|}
\hline Run No. & $\begin{array}{l}\text { Air Rate } \\
\text { CFM } \\
\end{array}$ & $\begin{array}{l}\text { Water Rate } \\
\text { CFM } \\
\end{array}$ & $\begin{array}{l}\text { Holdup } \\
\text { cc }\end{array}$ & $\begin{array}{c}\text { Pressure } \\
\text { Gage, psig } \\
\end{array}$ & $\begin{array}{c}\text { Pressure } \\
\text { Drop, In. Hg }\end{array}$ \\
\hline \multicolumn{6}{|c|}{ Air-Water Runs (Continued) } \\
\hline 216 & 1.73 & 0.289 & 1090 & 4.2 & 6.1 \\
\hline 217 & 2.31 & 0.289 & 1090 & 4.0 & 5.8 \\
\hline 252 & 23.8 & 0.251 & 430 & 5.4 & 6.0 \\
\hline 253 & 26.8 & 0.247 & 390 & 5.8 & 6.3 \\
\hline 254 & 31.2 & 0.238 & 375 & 6.2 & 6.6 \\
\hline
\end{tabular}

$G=100$

$\begin{array}{rrrrrr}93 & 0.010 & 0.58 & 3430 & 10.2 & 17.75 \\ 94 & 0.046 & 0.58 & 3320 & 10.0 & 17.2 \\ 95 & 0.104 & 0.58 & 3115 & 9.5 & 16.0 \\ 96 & 0.176 & 0.58 & 2950 & 9.0 & 15.2 \\ 97 & 0.25 & 0.58 & 2795 & 8.6 & 14.2 \\ 98 & 0.323 & 0.58 & 2615 & 8.1 & 13.4 \\ 115 & 2.58 & 0.58 & 1230 & 6.8 & 8.5 \\ 116 & 3.66 & 0.58 & 1090 & 6.0 & 8.6 \\ 117 & 4.63 & 0.58 & 1035 & 6.0 & 8.6 \\ 118 & 5.63 & 0.58 & 950 & 6.0 & 8.6 \\ 119 & 6.63 & 0.58 & 905 & 6.5 & 8.8 \\ 156 & 0.37 & 0.58 & 2510 & 8.0 & 12.8 \\ 166 & 4.2 & 0.57 & 1095 & 6.0 & 8.8 \\ 167 & 6.45 & 0.57 & 940 & 6.5 & 9.3 \\ 168 & 8.95 & 0.565 & 835 & 6.5 & 9.3 \\ 169 & 11.3 & 0.56 & 770 & 7.0 & 9.7 \\ 170 & 13.8 & 0.555 & 700 & 7.2 & 9.9 \\ 171 & 16.3 & 0.55 & 660 & 8.0 & 10.4 \\ 172 & 18.8 & 0.543 & 630 & 8.5 & 10.6 \\ 206 & 0.56 & 0.58 & 2225 & 7.2 & 11.25 \\ 207 & 0.80 & 0.58 & 1870 & 6.6 & 10.1 \\ 208 & 1.07 & 0.58 & 1660 & 6.4 & 9.5 \\ 209 & 1.36 & 0.58 & 1560 & 6.0 & 8.9 \\ 210 & 1.65 & 0.58 & 1440 & 5.7 & 8.5 \\ 211 & 2.21 & 0.58 & 1275 & 5.5 & 8.6 \\ 263 & 21.5 & 0.541 & 550 & 9.0 & 11.0 \\ 264 & 23.8 & 0.537 \ldots \ldots .5 & 530 & 9.5 & 11.3 \\ 265 & 26.9 & 0.528 & 505 & 10.5 & 11.5\end{array}$

$G=150$

$\begin{array}{llllll}40 & 0.355 & 0.87 & 2730 & 9.0 & 14.5 \\ 41 & 0.720 & 0.87 & 2300 & 8.1 & 12.5 \\ 42 & 1.46 & 0.87 & 1725 & 7.3 & 10.7 \\ 43 & 2.16 & 0.87 & 1510 & 7.5 & 10.2 \\ 44 & 2.83 & 0.87 & 1340 & 7.2 & 10.2 \\ 62 & 0.54 & 0.87 & 2450 & 8.5 & 13.3\end{array}$


Holdup and Pressure Drop Data

(Continued)

\begin{tabular}{|c|c|c|c|c|c|}
\hline Run No. & $\begin{array}{l}\text { Air Rate } \\
\text { CFM } \\
\end{array}$ & $\begin{array}{l}\text { Water Rate } \\
\text { CFM } \\
\end{array}$ & $\begin{array}{l}\text { Holdup } \\
\text { cc } \\
\end{array}$ & $\begin{array}{c}\text { Pressure } \\
\text { Gage, psig } \\
\end{array}$ & $\begin{array}{c}\text { Pressure } \\
\text { Drop, In. Hg } \\
\end{array}$ \\
\hline \multicolumn{5}{|c|}{ Air-Water Runs (Continued) } & \\
\hline 63 & 1.11 & 0.87 & 1905 & 7.5 & 11.3 \\
\hline 64 & 1.82 & 0.87 & 1605 & 7.3 & $\begin{array}{l}1 \pm .3 \\
10.3\end{array}$ \\
\hline 72 & 0.01 & 0.87 & 3450 & 10.4 & 18.1 \\
\hline 73 & 0.045 & 0.87 & 3390 & 10.4 & 17.7 \\
\hline 74 & 0.10 & 0.87 & 3240 & 10.1 & 17.0 \\
\hline 75 & 0.167 & 0.87 & 3110 & 9.9 & 16.3 \\
\hline 76 & 0.235 & 0.87 & 2950 & 9.5 & 15.6 \\
\hline 77 & 0.303 & 0.87 & 2840 & 9.2 & 14.9 \\
\hline 106 & 2.57 & 0.87 & 1480 & 7.5 & 10.5 \\
\hline 107 & 3.47 & 0.87 & 1330 & 7.7 & 10.6 \\
\hline 108 & 4.3 & 0.87 & 1170 & 8.1 & 10.8 \\
\hline 109 & 5.33 & 0.87 & 1100 & 8.0 & 11.4 \\
\hline 110 & 5.95 & 0.87 & 1095 & 8.5 & 11.6 \\
\hline 155 & 0.36 & 0.87 & 2730 & 9.0 & 14.4 \\
\hline 159 & 3.9 & 0.855 & 1165 & 8.0 & 11.2 \\
\hline 160 & 6.05 & 0.855 & 1040 & 8.5 & 12.1 \\
\hline 161 & 8.15 & 0.85 & 950 & 9.2 & 12.4 \\
\hline 162 & 10.2 & 0.845 & 870 & 10.0 & 13.0 \\
\hline 163 & 12.2 & 0.841 & 820 & 10.8 & 13.9 \\
\hline 164 & 14.5 & 0.838 & 760 & 11.5 & 14.4 \\
\hline 165 & 16.6 & 0.833 & 690 & 12.5 & 15.3 \\
\hline 200 & 0.525 & 0.87 & 2485 & 8.3 & 13.0 \\
\hline 201 & 0.76 & 0.87 & 2230 & 8.0 & 12.2 \\
\hline 202 & 1.03 & 0.87 & 2050 & 7.7 & 11.5 \\
\hline 203 & 1.29 & 0.87 & 1840 & 7.5 & 11.8 \\
\hline 204 & 1.55 & 0.87 & 1710 & 7.3 & 10.7 \\
\hline 205 & 2.08 & 0.87 & 1500 & 7.0 & 10.3 \\
\hline 272 & 18.8 & 0.83 & 680 & 13.0 & 15.8 \\
\hline 273 & 21.1 & 0.827 & 625 & 13.5 & 16.5 \\
\hline 274 & 24.2 & 0.82 & 580 & 14.5 & 17.7 \\
\hline
\end{tabular}


Holdup and Pressure Drop Data

(Continued)

Run No. \begin{tabular}{ccccc}
$\begin{array}{c}\text { Air Rate } \\
\text { CFM }\end{array}$ & $\begin{array}{c}\text { Liquid Rate } \\
\text { CFM }\end{array}$ & $\begin{array}{c}\text { Holdup } \\
\text { cc }\end{array}$ & $\begin{array}{c}\text { Pressure } \\
\text { Gage, psig }\end{array}$ & $\begin{array}{c}\text { Pressure } \\
\text { Drop, In. Hg }\end{array}$ \\
\hline
\end{tabular}

Air-Sodium Carbonate Solution Runs

$G=5$

$\begin{array}{rllrrr}371 & 0.0096 & 0.0244 & 3380 & 11.4 & 20.1 \\ 372 & 0.044 & 0.0244 & 2970 & 10.0 & 17.4 \\ 373 & 0.130 & 0.0244 & 2120 & 7.3 & 11.1 \\ 374 & 0.210 & 0.0241 & 1685 & 5.8 & 8.8 \\ 375 & 0.325 & 0.0240 & 1350 & 4.8 & 7.1 \\ 376 & 0.413 & 0.0237 & 1305 & 4.3 & 6.1 \\ 377 & 0.735 & 0.0234 & 1075 & 3.5 & 4.7 \\ 378 & 1.19 & 0.0229 & 910 & 3.1 & 3.8 \\ 379 & 1.65 & 0.0223 & 875 & 2.9 & 3.6 \\ 380 & 1.98 & 0.0218 & 800 & 2.8 & 3.6 \\ 381 & 2.25 & 0.0210 & 775 & 2.9 & 3.4 \\ 382 & 3.5 & 0.0202 & 730 & 3.0 & 3.6 \\ 383 & 5.98 & 0.0171 & 585 & 2.6 & 3.3 \\ 384 & 10.4 & 0.0124 & 415 & 2.2 & 2.3 \\ 402 & 13.5 & 0.0065 & 325 & 2.3 & 2.0 \\ 403 & 16.4 & 0.004 & 220 & 2.0 & 1.5 \\ 404 & 18.0 & 0.003 & 180 & 2.0 & 1.1\end{array}$

$G=10$

$\begin{array}{llllll}357 & 0.0099 & 0.0485 & 3400 & 11.4 & 20.9 \\ 358 & 0.044 & 0.0485 & 3000 & 10.0 & 17.8 \\ 359 & 0.132 & 0.0485 & 2235 & 7.8 & 12.6 \\ 360 & 0.205 & 0.0483 & 1925 & 6.5 & 11.0 \\ 361 & 0.315 & 0.0482 & 1540 & 5.4 & 7.75 \\ 362 & 0.405 & 0.0481 & 1470 & 4.8 & 7.25 \\ 363 & 0.725 & 0.0479 & 1090 & 3.7 & 5.0 \\ 364 & 1.175 & 0.0473 & 970 & 3.3 & 4.3 \\ 365 & 1.64 & 0.0468 & 850 & 3.0 & 4.0 \\ 366 & 1.96 & 0.0463 & 890 & 3.0 & 3.9 \\ 367 & 2.24 & 0.0460 & 870 & 3.0 & 3.8 \\ 368 & 3.46 & 0.0445 & 780 & 3.2 & 4.2 \\ 369 & 5.85 & 0.0417 & 645 & 3.0 & 3.75 \\ 370 & 10.1 & 0.037 & 470 & 2.4 & 2.9 \\ 395 & 10.1 & 0.037 & 485 & 2.6 & 3.0 \\ 396 & 13.5 & 0.0333 & 380 & 2.4 & 2.4 \\ 397 & 16.4 & 0.0297 & 295 & 2.1 & 2.1 \\ 398 & 19.3 & 0.026 & 240 & 2.5 & 2.1 \\ 399 & 23.5 & 0.0213 & 200 & 2.4 & 1.8 \\ 400 & 26.6 & 0.0175 & 165 & 2.4 & 1.9 \\ 401 & 33.0 & 0.0087 & 130 & 2.9 & 1.9\end{array}$


Holdup and Pressure Drop Data

(Continued)

Run No. $\begin{gathered}\begin{array}{c}\text { Air Rate } \\ \text { CFM }\end{array} \\ \text { Air-Sodium Carbonate Solution Runs (Continued) }\end{gathered}$

$G=25$

$\begin{array}{llll}343 & 0.0096 & 0.122 & 3425 \\ 344 & 0.0435 & 0.122 & 3120 \\ 345 & 0.130 & 0.122 & 2550 \\ 346 & 0.201 & 0.122 & 2200 \\ 347 & 0.305 & 0.122 & 1905 \\ 348 & 0.39 & 0.122 & 1745 \\ 349 & 0.69 & 0.122 & 1370 \\ 350 & 1.15 & 0.122 & 1200 \\ 351 & 1.60 & 0.122 & 1025 \\ 352 & 1.94 & 0.122 & 990 \\ 353 & 2.18 & 0.120 & 925 \\ 354 & 3.45 & 0.116 & 770 \\ 355 & 5.8 & 0.113 & 750 \\ 356 & 9.95 & 0.109 & 560 \\ 391 & 12.8 & 0.107 & 490 \\ 392 & 15.6 & 0.103 & 410 \\ 393 & 18.7 & 0.099 & 350 \\ 394 & 22.6 & 0.0941 & 310 \\ 417 & 25.6 & 0.0925 & 265 \\ 418 & 31.0 & 0.0865 & 215\end{array}$

11.5

21.5

$10.5 \quad 18.5$

$8.9 \quad 14.7$

$7.6 \quad 12.6$

$6.6 \quad 10.4$

6.19 .2

$5.0 \quad 6.9$

$4.1 \quad 5.6$

$3.8 \quad 5.3$

$3.6 \quad 5.0$

$3.7 \quad 4.85$

$3.5 \quad 5.4$

$3.5 \quad 4.8$

$3.2 \quad 4.1$

$3.1 \quad 3.9$

$3.4 \quad 3.6$

$3.5 \quad 3.9$

$3.4 \quad 3.6$

$4.9 \quad 3.8$

$G=50$

$\begin{array}{rlllrl}329 & 0.0096 & 0.243 & 3450 & 11.7 & 20.7 \\ 330 & 0.043 & 0.243 & 3225 & 11.0 & 19.2 \\ 331 & 0.124 & 0.243 & 2800 & 9.6 & 16.7 \\ 332 & 0.195 & 0.243 & 2500 & 8.7 & 15.0 \\ 333 & 0.296 & 0.243 & 2210 & 7.7 & 12.3 \\ 334 & 0.38 & 0.243 & 2080 & 7.1 & 11.5 \\ 335 & 0.673 & 0.243 & 1680 & 6.1 & 9.0 \\ 336 & 1.07 & 0.243 & 1330 & 5.2 & 7.3 \\ 337 & 1.52 & 0.243 & 1155 & 4.8 & 7.2 \\ 338 & 1.86 & 0.243 & 1055 & 4.6 & 6.6 \\ 339 & 2.12 & 0.243 & 1040 & 4.5 & 6.5 \\ 340 & 3.36 & 0.237 & 975 & 4.4 & 6.9 \\ 341 & 5.6 & 0.234 & 765 & 4.5 & 6.8 \\ 342 & 9.43 & 0.231 & 690 & 4.5 & 5.8 \\ 389 & 14.7 & 0.225 & 515 & 5.0 & 5.9 \\ 390 & 21.0 & 0.213 & 440 & 5.3 & 6.2 \\ 415 & 25.4 & 0.21 & 380 & 5.7 & 6.6 \\ 416 & 28.9 & 0.204 & 320 & 6.6 & 6.9\end{array}$


Holdup and Pressure Drop Data

(Continued)

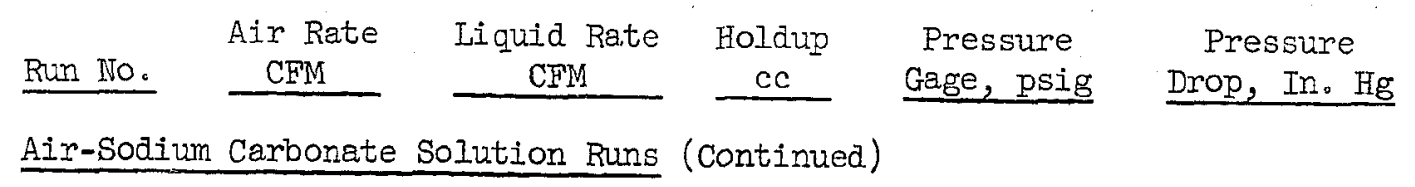

$G=100$

$\begin{array}{rlllrl}315 & 0.0096 & 0.485 & & 12.2 & 21.0 \\ 316 & 0.043 & 0.485 & 3340 & 11.7 & 20.1 \\ 317 & 0.122 & 0.485 & 3025 & 10.6 & 18.3 \\ 318 & 0.185 & 0.485 & 2820 & 10.1 & 16.9 \\ 319 & 0.280 & 0.485 & 2570 & 9.4 & 15.2 \\ 320 & 0.357 & 0.485 & 2460 & 9.0 & 14.4 \\ 321 & 0.66 & 0.485 & 2060 & 7.7 & 11.9 \\ 322 & 1.05 & 0.485 & 1650 & 6.8 & 11.5 \\ 323 & 1.46 & 0.485 & 1495 & 6.5 & 9.6 \\ 324 & 1.76 & 0.485 & 1410 & 6.3 & 9.4 \\ 325 & 1.99 & 0.485 & 1270 & 6.3 & 9.0 \\ 326 & 2.15 & 0.477 & 1270 & 6.2 & 9.0 \\ 327 & 5.30 & 0.472 & 930 & 6.0 & 9.3 \\ 328 & 8.9 & 0.470 & 720 & 6.5 & 9.6 \\ 387 & 13.5 & 0.466 & 610 & 7.5 & 9.5 \\ 388 & 19.2 & 0.458 & 570 & 8.0 & 10.4 \\ 413 & 22.5 & 0.452 & 505 & 9.0 & 10.4 \\ 414 & 25.9 & 0.445 & 475 & 10.0 & 11.5\end{array}$

$\mathrm{G}=150$

$\begin{array}{llllll}300 & 0.0094 & 0.73 & 3460 & 12.2 & 21.35 \\ 301 & 0.0416 & 0.73 & 3410 & 12.0 & 20.9 \\ 302 & 0.094 & 0.73 & 3300 & 11.9 & 19.9 \\ 303 & 0.159 & 0.73 & 3075 & 11.3 & 18.9 \\ 304 & 0.207 & 0.73 & 2960 & 11.0 & 18.2 \\ 305 & 0.273 & 0.73 & 2790 & 10.5 & 17.4 \\ 306 & 0.345 & 0.73 & 2700 & 10.2 & 16.7 \\ 307 & 0.610 & 0.73 & 2340 & 9.2 & 14.75 \\ 308 & 0.994 & 0.73 & 2025 & 8.5 & 13.1 \\ 309 & 1.39 & 0.73 & 1735 & 8.0 & 12.0 \\ 310 & 1.66 & 0.73 & 1610 & 7.8 & 11.65 \\ 311 & 1.90 & 0.73 & 1510 & 7.7 & 11.4 \\ 312 & 2.06 & 0.72 & 1505 & 7.5 & 11.3 \\ 313 & 4.95 & 0.717 & 1070 & 8.2 & 12.1 \\ 314 & 8.1 & 0.714 & 925 & 9.2 & 13.1 \\ 385 & 12.8 & 0.711 & 765 & 9.6 & 14.1 \\ 386 & 17.1 & 0.695 & 625 & 11.5 & 14.6 \\ 411 & 20.3 & 0.695 & 605 & 12.5 & 15.2 \\ 412 & 23.2 & 0.690 & 530 & 13.5 & 15.6\end{array}$


Holdup and Pressure Drop Data

(Contimued)

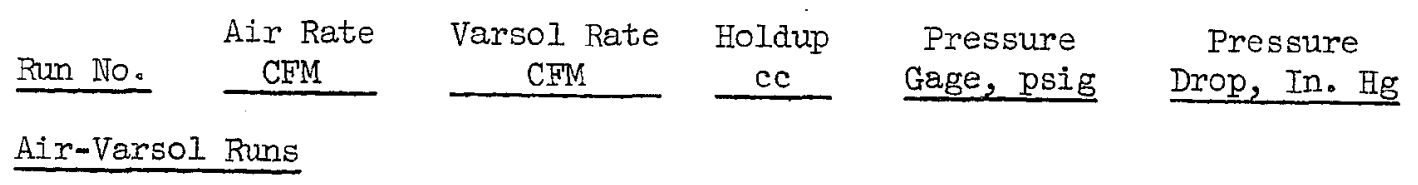

$G=5$

$\begin{array}{lllr}594 & 0.0107 & 0.037 & 3270 \\ 595 & 0.0483 & 0.037 & 2780 \\ 596 & 0.146 & 0.037 & 1840 \\ 597 & 0.23 & 0.037 & 1450 \\ 598 & 0.346 & 0.0365 & 1170 \\ 599 & 0.441 & 0.0363 & 970 \\ 600 & 0.773 & 0.0357 & 935 \\ 601 & 1.24 & 0.0351 & 810 \\ 602 & 1.68 & 0.0344 & 910 \\ 603 & 2.0 & 0.0336 & 825 \\ 604 & 2.31 & 0.0334 & 840 \\ 605 & 3.6 & 0.0312 & 720 \\ 606 & 6.15 & 0.0271 & 515 \\ 607 & 10.5 & 0.0198 & 280 \\ 608 & 15.1 & 0.0111 & 140 \\ 609 & 15.9 & 0.0097 & 130\end{array}$

7.9

13.0

6.6

10.8

4.4

6.7

3.6

5.1

3.0

2.6

2.3

3.9

3.2

935

810

2.6

2.2

2.5

2.4

2.6

2.3

2.6

2.3

2.7

2.3

2.6

2.0

2.0

1.6

1.1

1.5

0.7

1.5

0.7

$G=10$

$\begin{array}{lllr}570 & 0.0108 & 0.0737 & 3260 \\ 571 & 0.0487 & 0.0737 & 2900 \\ 572 & 0.143 & 0.0737 & 2020 \\ 573 & 0.225 & 0.0737 & 1550 \\ 574 & 0.342 & 0.0737 & 1310 \\ 575 & 0.435 & 0.073 & 1180 \\ 576 & 0.77 & 0.0722 & 1020 \\ 577 & 1.22 & 0.0715 & 920 \\ 578 & 1.68 & 0.0708 & 950 \\ 579 & 2.0 & 0.070 & 930 \\ 580 & 2.29 & 0.0695 & 910 \\ 581 & 3.58 & 0.0675 & 770 \\ 582 & 6.15 & 0.062 & 580 \\ 583 & 10.3 & 0.0555 & 380 \\ 584 & 14.8 & 0.0485 & 230 \\ 585 & 19.7 & 0.040 & 160 \\ 586 & 27.0 & 0.027 & 100 \\ 587 & 36.0 & 0.010 & 50\end{array}$

$7 \cdot 9$

13.2

6.9

5.0

11.3

4.1

3.3

3.0

2.5

2.5

2. 5

2.5

2.6

2.5

2. 1

2.0

1.9

2.1

2.2

2.3

7.7

6.1

4.6

4.1

3.0

2.8

2.9

3.1

3.2

2.8

2.3

1.7

1.4

1.3

1.3

$G=25$

$\begin{array}{llll}516 & 0.0107 & 0.184 & 3425 \\ 517 & 0.049 & 0.184 & 3150 \\ 518 & 0.139 & 0.184 & 2485\end{array}$

$\begin{array}{rr}8.0 & 13.5 \\ 7.5 & 12.4 \\ 6.1 & 9.9\end{array}$


Holdup and Pressure Drop Data

(Continued

\begin{tabular}{|c|c|c|c|c|c|}
\hline Run No. & $\begin{array}{c}\text { Air Rate } \\
\text { CFM } \\
\end{array}$ & $\begin{array}{c}\text { Varsol Rate } \\
\text { CFM } \\
\end{array}$ & $\begin{array}{c}\text { Holdup } \\
\mathrm{cc} \\
\end{array}$ & $\begin{array}{l}\text { Pressure } \\
\text { Gage, psig } \\
\end{array}$ & $\begin{array}{c}\text { Pressure } \\
\text { Drop, In. } \mathrm{Hg}\end{array}$ \\
\hline \multicolumn{6}{|c|}{ Air-Varsol Runs (Continued) } \\
\hline 519 & 0.209 & 0.184 & 2000 & 5.3 & 8.3 \\
\hline 520 & 0.330 & 0.184 & 1730 & 4.4 & 6.5 \\
\hline 521 & 0.42 & 0.184 & 1550 & 4.1 & 6.1 \\
\hline 522 & 0.745 & 0.184 & 1.170 & 3.3 & 4.4 \\
\hline 523 & 1.14 & 0.184 & 1020 & 2.7 & 3.7 \\
\hline 524 & 1.67 & 0.184 & 910 & 2.7 & 3.5 \\
\hline 525 & 1.98 & 0.184 & 960 & 2.7 & 3.7 \\
\hline 526 & 2.27 & 0.184 & 880 & 2.8 & 3.8 \\
\hline 527 & 2.4 & 0.18 & 855 & 2.8 & 3.8 \\
\hline 528 & 6.0 & 0.174 & 630 & 2.7 & 3.0 \\
\hline 529 & 10.1 & 0.166 & 450 & 2.5 & 2.7 \\
\hline 530 & 14.7 & 0.158 & 360 & 2.6 & 2.7 \\
\hline 531 & 19.4 & 0.149 & 320 & 2.9 & 2.8 \\
\hline 532 & 25.6 & 0.137 & 220 & 3.2 & 2.9 \\
\hline 533 & 33.4 & 0.120 & 160 & 4.0 & 3.1 \\
\hline
\end{tabular}

$G=50$

\begin{tabular}{|c|c|c|c|c|c|}
\hline & & & & & \\
\hline 534 & 0.0485 & 0.368 & 3280 & 7.9 & 13.1 \\
\hline 535 & 0.135 & 0.368 & 2820 & 7.0 & 11.4 \\
\hline 536 & 0.209 & 0.368 & 2490 & 6.5 & 10.2 \\
\hline 537 & 0.318 & 0.368 & 2110 & 5.6 & 8. \\
\hline 538 & 0.40 & 0.368 & 1960 & 5.3 & 8. \\
\hline 539 & 0.725 & 0.368 & 1510 & 4.3 & 6. \\
\hline 540 & 1.10 & 0.368 & 1230 & 3.7 & 5 \\
\hline 541 & 1.62 & 0.368 & 1140 & 3.6 & 4 \\
\hline $5^{4} \cdot 2$ & 1.91 & 0.368 & 1050 & 3.5 & 4 \\
\hline 543 & 2.21 & 0.368 & 1010 & 3.5 & 4. \\
\hline 544 & 3.47 & 0.362 & 860 & 3.3 & 4. \\
\hline 545 & 5.83 & 0.359 & 690 & 3.3 & 4. \\
\hline 546 & 9.8 & 0.351 & 530 & 3.5 & 4. \\
\hline 547 & 13.8 & 0.343 & 440 & 4.0 & 4. \\
\hline 548 & 18.5 & 0.333 & 380 & 4.2 & 4. \\
\hline 549 & 24.1 & 0.32 & 310 & 5.0 & 5. \\
\hline 50 & 30.8 & 0.304 & 290 & 6.1 & 5. \\
\hline \multicolumn{6}{|c|}{$G=100$} \\
\hline 500 & 0.132 & 0.737 & 3070 & 8.0 & 12. \\
\hline 01 & 0.204 & 0.737 & 2870 & 7.5 & 12.0 \\
\hline 502 & 0.305 & 0.737 & 2610 & 7.0 & 11.0 \\
\hline 503 & 0.387 & 0.737 & 2470 & 6.7 & 10. \\
\hline & 0.685 & 0.737 & 2220 & 6.5 & 9. \\
\hline 50 & 1.03 & 0.737 & 1740 & 5.5 & 7. \\
\hline & 1.54 & 0.737 & 1520 & 5.1 & $7 \cdot 2$ \\
\hline
\end{tabular}


Holdup and Pressure Drop Data

(Continued)

\begin{tabular}{|c|c|c|c|c|c|}
\hline Run No. & $\begin{array}{l}\text { Air Rate } \\
\text { CFM } \\
\end{array}$ & $\begin{array}{c}\text { Varsol Rate } \\
\text { CFM } \\
\end{array}$ & $\begin{array}{l}\text { Holdup } \\
\mathrm{cc} \\
\end{array}$ & $\begin{array}{c}\text { Pressure } \\
\text { Gage, psig } \\
\end{array}$ & $\begin{array}{c}\text { Pressure } \\
\text { Drop, In. Hg }\end{array}$ \\
\hline \multicolumn{6}{|c|}{ Air-Varsol Runs (Continued) } \\
\hline $\begin{array}{l}507 \\
508 \\
509 \\
510 \\
511 \\
512 \\
513 \\
514 \\
515\end{array}$ & $\begin{array}{c}1.82 \\
2.10 \\
2.21 \\
5.47 \\
8.1 \\
12.5 \\
16.2 \\
21.1 \\
27.0\end{array}$ & $\begin{array}{l}0.737 \\
0.737 \\
0.732 \\
0.725 \\
0.719 \\
0.703 \\
0.695 \\
0.69 \\
0.675\end{array}$ & $\begin{array}{r}1385 \\
1310 \\
1260 \\
830 \\
670 \\
590 \\
510 \\
460 \\
390\end{array}$ & $\begin{array}{r}5.0 \\
5.0 \\
4.9 \\
5.3 \\
6.3 \\
6.8 \\
7.6 \\
8.6 \\
10.0\end{array}$ & $\begin{array}{l}6.8 \\
6.8 \\
6.5 \\
6.8 \\
7.1 \\
7.9 \\
8.3 \\
8.7 \\
9.6\end{array}$ \\
\hline \multicolumn{6}{|c|}{$\mathrm{G}=150$} \\
\hline $\begin{array}{l}554 \\
555 \\
556 \\
557 \\
558 \\
559 \\
560 \\
561 \\
562 \\
563 \\
564 \\
565 \\
566\end{array}$ & $\begin{array}{l}0.129 \\
0.20 \\
0.296 \\
0.38 \\
0.657 \\
0.98 \\
1.43 \\
1.69 \\
1.96 \\
3.06 \\
5.98 \\
8.91 \\
13.3\end{array}$ & $\begin{array}{l}1.11 \\
1.11 \\
1.11 \\
1.11 \\
1.11 \\
1.11 \\
1.11 \\
1.11 \\
1.11 \\
1.1 \\
1.1 \\
1.09 \\
1.08\end{array}$ & $\begin{array}{l}3045 \\
2960 \\
2790 \\
2665 \\
2290 \\
1990 \\
1740 \\
1660 \\
1580 \\
1300 \\
930 \\
750 \\
620\end{array}$ & $\begin{array}{r}8.3 \\
7.9 \\
7.8 \\
7.6 \\
7.1 \\
6.9 \\
6.7 \\
6.7 \\
6.6 \\
6.8 \\
8.0 \\
9.5 \\
10.5\end{array}$ & $\begin{array}{r}13.1 \\
12.9 \\
12.2 \\
12.0 \\
10.5 \\
9.5 \\
8.8 \\
8.6 \\
8.4 \\
8.1 \\
9.1 \\
10.1 \\
10.8\end{array}$ \\
\hline
\end{tabular}


Holdup and Pressure Drop Data

(Continued)

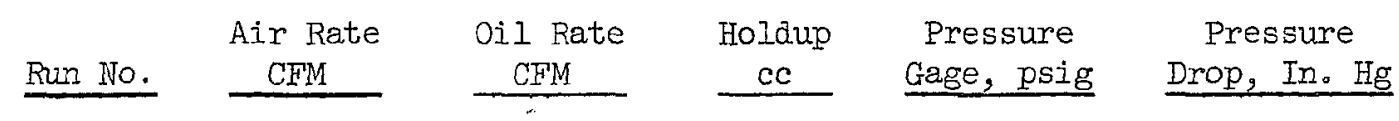

Air-0il Blend No. 1 Runs

$G=5$

$\begin{array}{llllll}785 & 0.0107 & 0.035 & 3330 & 8.1 & 13.8 \\ 786 & 0.0493 & 0.035 & 2750 & 7.0 & 11.2 \\ 787 & 0.143 & 0.035 & 1970 & 4.9 & 7.4 \\ 788 & 0.225 & 0.035 & 1630 & 4.0 & 5.9 \\ 789 & 0.338 & 0.035 & 1420 & 3.5 & 4.8 \\ 790 & 0.427 & 0.034 & 1370 & 3.4 & 4.5 \\ 791 & 0.76 & 0.0335 & 1190 & 2.9 & 3.8 \\ 792 & 1.14 & 0.0328 & 1060 & 2.5 & 3.1 \\ 793 & 1.68 & 0.032 & 910 & 2.4 & 2.9 \\ 794 & 2.3 & 0.0312 & 880 & 2.3 & 2.9 \\ 795 & 3.6 & 0.029 & 740 & 2.0 & 2.7 \\ 796 & 7.55 & 0.0227 & 530 & 2.0 & 2.1 \\ 797 & 11.75 & 0.0154 & 330 & 2.0 & 1.4 \\ 798 & 14.8 & 0.0105 & 260 & 2.0 & 1.4 \\ 799 & 18.2 & 0.0049 & 180 & 2.0 & 1.2 \\ 800 & 20.0 & 0.0021 & 110 & 1.9 & 1.0\end{array}$

$G=10$

$\begin{array}{llllll}766 & 0.0106 & 0.070 & 3360 & 8.3 & 14.0 \\ 767 & 0.048 & 0.070 & 2910 & 7.3 & 12.0 \\ 768 & 0.140 & 0.070 & 2140 & 5.5 & 8.5 \\ 769 & 0.22 & 0.070 & 1810 & 4.6 & 6.9 \\ 770 & 0.334 & 0.070 & 1570 & 3.9 & 5.5 \\ 771 & 0.425 & 0.069 & 1340 & 3.7 & 5.1 \\ 772 & 0.75 & 0.0685 & 1240 & 3.2 & 4.2 \\ 773 & 1.14 & 0.068 & 1100 & 2.7 & 3.75 \\ 774 & 1.67 & 0.067 & 980 & 2.6 & 3.2 \\ 775 & 2.27 & 0.0662 & 870 & 2.6 & 3.2 \\ 776 & 3.57 & 0.064 & 710 & 2.5 & 3.1 \\ 777 & 7.4 & 0.0575 & 600 & 2.4 & 2.7 \\ 778 & 13.4 & 0.048 & 410 & 2.0 & 2.0 \\ 779 & 19.7 & 0.037 & 280 & 2.3 & 2.0 \\ 780 & 26.7 & 0.0238 & 170 & 2.5 & 2.1 \\ 781 & 34.9 & 0.0094 & 80 & 3.0 & 2.3\end{array}$

$G=25$

$\begin{array}{llllll}715 & 0.049 & 0.175 & 3140 & 7.9 & 13.2 \\ 716 & 0.137 & 0.175 & 2620 & 6.7 & 10.8 \\ 717 & 0.216 & 0.175 & 2290 & 5.8 & 9.3 \\ 718 & 0.327 & 0.175 & 2010 & 5.0 & 7.9 \\ 719 & 0.417 & 0.175 & 1820 & 4.8 & 7.2\end{array}$


Holdup and Pressure Drop Data
(Continued)

\begin{tabular}{|c|c|c|c|c|c|}
\hline Run No. & $\begin{array}{l}\text { Air Rate } \\
\text { CFM } \\
\end{array}$ & $\begin{array}{l}\text { Oil Rate } \\
\text { CFM } \\
\end{array}$ & $\begin{array}{l}\text { Holdup } \\
\text { ec } \\
\end{array}$ & $\begin{array}{c}\text { Pressure } \\
\text { Gage, psig } \\
\end{array}$ & $\begin{array}{r}\text { Pressu } \\
\text { Drop, In } \\
\end{array}$ \\
\hline \multicolumn{6}{|c|}{ Air-Oil Blend No. 1 Runs (Continued) } \\
\hline 720 & 0.737 & 0.175 & 1530 & 4.0 & 5.8 \\
\hline 721 & 1.12 & 0.175 & 1340 & 3.5 & 5.8 \\
\hline 722 & 1.65 & 0.175 & 1135 & 3.2 & \\
\hline 723 & 2.24 & 0.175 & 1090 & 3.2 & 4.2 \\
\hline 724 & 3.5 & 0.170 & 960 & 3.2 & 4. \\
\hline 725 & 7.33 & 0.162 & 670 & 2.9 & 3. \\
\hline 726 & 12.8 & 0.155 & 525 & 3.2 & 3. \\
\hline 727 & 18.8 & 0.142 & 440 & 3.5 & 3. \\
\hline 728 & 25.2 & 0.130 & 330 & 3.9 & 30 \\
\hline 729 & 33.0 & 0.114 & 270 & 4.5 & 4. \\
\hline
\end{tabular}

$$
G=50
$$

$\begin{array}{llllll}732 & 0.0473 & 0.35 & 3250 & 8.4 & 13.7 \\ 733 & 0.133 & 0.35 & 2940 & 7.5 & 12.4 \\ 734 & 0.207 & 0.35 & 2700 & 7.0 & 11.8 \\ 735 & 0.308 & 0.35 & 2390 & 6.5 & 10.0 \\ 736 & 0.395 & 0.35 & 2260 & 6.0 & 9.3 \\ 737 & 0.708 & 0.35 & 1830 & 5.0 & 7.5 \\ 738 & 1.07 & 0.35 & 1570 & 4.5 & 6.4 \\ 739 & 1.59 & 0.35 & 1390 & 4.0 & 5.9 \\ 740 & 2.17 & 0.35 & 1170 & 4.0 & 5.5 \\ 741 & 3.41 & 0.344 & 940 & 3.8 & 5.3 \\ 742 & 7.04 & 0.338 & 750 & 4.0 & 5.4 \\ 743 & 12.2 & 0.328 & 540 & 4.5 & 5.7 \\ 744 & 17.9 & 0.317 & 440 & 5.0 & 5.9 \\ 745 & 23.7 & 0.305 & 380 & 5.5 & 5.8 \\ 746 & 30.6 & 0.289 & 350 & 6.5 & 6.2\end{array}$

$G=100$

$\begin{array}{rlllll}700 & 0.0466 & 0.70 & 3200 & 8.9 & 14.6 \\ 701 & 0.129 & 0.70 & 3050 & 8.5 & 13.7 \\ 702 & 0.199 & 0.70 & 2945 & 8.1 & 13.1 \\ 703 & 0.297 & 0.70 & 2715 & 7.7 & 12.1 \\ 704 & 0.377 & 0.70 & 2580 & 7.5 & 11.6 \\ 705 & 0.67 & 0.70 & 2220 & 6.8 & 10.3 \\ 706 & 1.0 & 0.70 & 1920 & 6.3 & 9.0 \\ 707 & 1.49 & 0.70 & 1640 & 5.9 & 8.4 \\ 708 & 2.04 & 0.70 & 1410 & 5.7 & 7.8 \\ 709 & 3.17 & 0.692 & 1140 & 5.7 & 7.6 \\ 710 & 6.4 & 0.686 & 890 & 6.5 & 8.6 \\ 711 & 10.9 & 0.67 & 690 & 7.5 & 9.4 \\ 712 & 15.7 & 0.66 & 600 & 8.5 & 9.6 \\ 713 & 20.3 & 0.655 & 510 & 9.7 & 10.1 \\ 714 & 26.3 & 0.64 & 465 & 10.7 & 10.6\end{array}$


Holdup and Pressure Drop Data

(Continued)

\begin{tabular}{|c|c|c|c|c|c|}
\hline Run No. & $\begin{array}{l}\text { Air Rate } \\
\text { CFM } \\
\end{array}$ & $\begin{array}{c}\text { Oil Rate } \\
\text { CFM } \\
\end{array}$ & $\begin{array}{l}\text { Holdup } \\
\mathrm{cc} \\
\end{array}$ & $\begin{array}{c}\text { Pressure } \\
\text { Gage, psig } \\
\end{array}$ & $\begin{array}{l}\text { Pressure } \\
\text { Drop, In. Hg } \\
\end{array}$ \\
\hline \multicolumn{6}{|c|}{ Air-Oil Blend No. 1 Runs (Continued) } \\
\hline \multicolumn{6}{|c|}{$G=150$} \\
\hline 750 & 0.125 & 1.05 & 3150 & 9.1 & 14.3 \\
\hline 751 & 0.195 & 1.05 & 3080 & 8.8 & 14.0 \\
\hline 752 & 0.29 & 1.05 & 2930 & 8.6 & 13.5 \\
\hline 753 & 0.366 & 1.05 & 2860 & 8.5 & 13.2 \\
\hline 754 & 0.64 & 1.05 & 2510 & 8.0 & 12.1 \\
\hline 755 & 1.03 & 1.05 & 2230 & 7.6 & 11.0 \\
\hline 756 & 1.41 & 1.05 & 1960 & 7.5 & 10.4 \\
\hline 757 & 1.92 & 1.05 & 1740 & 7.3 & 9.9 \\
\hline 758 & 2.96 & 1.045 & 1360 & 7.6 & 9.7 \\
\hline 759 & 5.87 & $1: 035$ & 970 & 8.8 & 10.8 \\
\hline 760 & 9.85 & 1.025 & 790 & 10.6 & 12.7 \\
\hline 761 & 13.7 & 1.02 & 660 & 12.5 & 13.4 \\
\hline 762 & 18.2 & 1.005 & 590 & 13.5 & 14.7 \\
\hline
\end{tabular}


Holdup and Pressure Drop Data

(Continued)

\begin{tabular}{|c|c|c|c|c|c|}
\hline Run No. & $\begin{array}{c}\text { Air Rate } \\
\text { CFM } \\
\end{array}$ & $\begin{array}{l}\text { Oil Rate } \\
\text { CFM } \\
\end{array}$ & $\begin{array}{c}\text { Holdup } \\
\mathrm{cc} \\
\end{array}$ & $\begin{array}{c}\text { Pressure } \\
\text { Gage, psig } \\
\end{array}$ & $\begin{array}{r}\text { Pressu } \\
\text { Drop, In } \\
\end{array}$ \\
\hline \multicolumn{6}{|c|}{ Air-0il Blend No. 2 Runs } \\
\hline \multicolumn{6}{|c|}{$G=25$} \\
\hline 942 & 0.0475 & 0.167 & 3160 & 8.4 & 13.9 \\
\hline 943 & 0.135 & 0.167 & 2780 & 7.0 & 11.7 \\
\hline 944 & 0.209 & 0.167 & 2570 & 6.5 & 10.4 \\
\hline 945 & 0.314 & 0.167 & 2300 & 5.8 & 9.2 \\
\hline 946 & 0.401 & 0.167 & 2170 & 5.5 & 8.5 \\
\hline 947 & 0.713 & 0.167 & 1900 & 4.8 & 7.2 \\
\hline 948 & 1.15 & 0.167 & 1630 & 4.3 & 6.2 \\
\hline 949 & 1.60 & 0.167 & 1450 & 3.9 & 5.7 \\
\hline 950 & 2.19 & 0.167 & 1280 & 3.8 & 5.6 \\
\hline 951 & 3.43 & 0.161 & 1100 & 3.7 & 5.4 \\
\hline 952 & 7.0 & 0.156 & 930 & 4.0 & 5.6 \\
\hline 953 & 12.3 & 0.145 & 790 & 4.4 & 5.8 \\
\hline 954 & 18.1 & 0.135 & 600 & 4.8 & 6.1 \\
\hline 955 & 24.4 & 0.124 & 490 & 5.0 & 6.3 \\
\hline 956 & 31.3 & 0.109 & 360 & 6.1 & 6.9 \\
\hline
\end{tabular}

$G=50$

$\begin{array}{rlllll}927 & 0.047 & 0.333 & 3270 & 8.9 & 15.0 \\ 928 & 0.130 & 0.333 & 3000 & 8.1 & 13.5 \\ 929 & 0.204 & 0.333 & 2800 & 7.5 & 12.5 \\ 930 & 0.306 & 0.333 & 2570 & 6.9 & 10.9 \\ 931 & 0.387 & 0.333 & 2430 & 6.7 & 10.7 \\ 932 & 0.685 & 0.333 & 2140 & 6.0 & 9.3 \\ 933 & 1.105 & 0.333 & 1810 & 5.5 & 8.3 \\ 934 & 1.55 & 0.333 & 1630 & 5.0 & 7.6 \\ 935 & 2.1 & 0.333 & 1440 & 5.0 & 7.4 \\ 936 & 3.28 & 0.327 & 1230 & 5.0 & 7.3 \\ 937 & 6.68 & 0.321 & 930 & 5.3 & 7.7 \\ 938 & 11.25 & 0.312 & 840 & 6.5 & 8.7 \\ 939 & 16.6 & 0.302 & 730 & 7.5 & 10.0 \\ 940 & 22.6 & 0.29 & 680 & 7.5 & 10.4 \\ 941 & 28.4 & 0.276 & 620 & 9.0 & 10.9 \\ & & & & & \\ G & 100 & & & & \\ 912 & 0.046 & 0.663 & 3340 & 9.5 & 16.25 \\ 913 & 0.125 & 0.663 & 3180 & 9.3 & 15.5 \\ 914 & 0.194 & 0.663 & 3040 & 9.0 & 14.9 \\ 915 & 0.291 & 0.663 & 2870 & 8.5 & 14.05 \\ 916 & 0.367 & 0.663 & 2740 & 8.4 & 13.6 \\ 917 & 0.65 & 0.663 & 2450 & 7.9 & 12.5 \\ 918 & 1.04 & 0.663 & 2230 & 7.5 & 11.6\end{array}$


Holdup and Pressure Drop Data

(Continued)

\begin{tabular}{|c|c|c|c|c|c|}
\hline Run No. & $\begin{array}{l}\text { Air Rate } \\
\text { CFM } \\
\end{array}$ & $\begin{array}{c}\text { Oil Rate } \\
\text { CFM } \\
\end{array}$ & $\begin{array}{c}\text { Holdup } \\
\mathrm{ce} \\
\end{array}$ & $\begin{array}{l}\text { Pressure } \\
\text { Gage, psig } \\
\end{array}$ & $\begin{array}{c}\text { Pressure } \\
\text { Drop, In. Hg }\end{array}$ \\
\hline \multicolumn{6}{|c|}{ Air-Oil Blend No. 2 Runs (Continued) } \\
\hline $\begin{array}{l}919 \\
920 \\
921 \\
922 \\
923 \\
924 \\
925 \\
926\end{array}$ & $\begin{array}{l}1.45 \\
1.95 \\
3.05 \\
6.15 \\
10.5 \\
14.8 \\
19.4 \\
25.7\end{array}$ & $\begin{array}{l}0.663 \\
0.663 \\
0.656 \\
0.651 \\
0.641 \\
0.630 \\
0.619 \\
0.605\end{array}$ & $\begin{array}{r}1990 \\
1660 \\
1330 \\
1060 \\
890 \\
690 \\
640 \\
650\end{array}$ & $\begin{array}{r}7.2 \\
7.2 \\
7.2 \\
8.1 \\
9.5 \\
11.0 \\
12.0 \\
13.5\end{array}$ & $\begin{array}{l}11.0 \\
10.6 \\
10.8 \\
12.1 \\
14.2 \\
15.0 \\
15.6 \\
16.8\end{array}$ \\
\hline \multicolumn{6}{|c|}{$G=150$} \\
\hline 900 & 0.123 & 0.995 & 3270 & 10.1 & 16.7 \\
\hline 901 & 0.188 & 0.995 & 3190 & 10.0 & 16.4 \\
\hline 902 & 0.28 & 0.995 & 3020 & 9.8 & 15.9 \\
\hline 903 & 0.355 & 0.995 & 2970 & 9.6 & 15.5 \\
\hline 904 & 0.62 & 0.995 & 2690 & 9.3 & 14.8 \\
\hline 905 & 0.99 & 0.995 & 2470 & 9.1 & 14.0 \\
\hline 906 & 1.36 & 0.995 & 2190 & 8.9 & 13.5 \\
\hline 907 & 1.86 & 0.995 & 1970 & 8.9 & 13.3 \\
\hline 908 & 2.82 & 0.99 & 1650 & 9.5 & 13.3 \\
\hline 909 & $5.6^{\circ}$ & 0.985 & 1210 & 10.7 & 15.0 \\
\hline 910 & 9.1 & 0.975 & 1040 & 13.5 & 17.3 \\
\hline 911 & 13.5 & 0.965 & 890 & 14.0 & 18.4 \\
\hline
\end{tabular}


Holdup and Pressure Drop Data

(Continued)

Run No. \begin{tabular}{c}
$\begin{array}{c}\text { Air Rate } \\
\text { CFM }\end{array}$ \\
\hline
\end{tabular}

Air-Trichloroethylene Runs

$G=37.5$

$\begin{array}{lllrrr}1013 & 0.125 & 0.153 & 2470 & 10.0 & 17.9 \\ 1014 & 0.197 & 0.153 & 2020 & 8.7 & 14.5 \\ 1015 & 0.30 & 0.153 & 1720 & 7.2 & 11.5 \\ 1016 & 0.39 & 0.153 & 1540 & 6.7 & 10.4 \\ 1017 & 0.705 & 0.153 & 1180 & 5.3 & 7.9 \\ 1018 & 1.13 & 0.153 & 1100 & 4.8 & 6.5 \\ 1019 & 1.57 & 0.153 & 930 & 4.8 & 6.8 \\ 1020 & 2.12 & 0.153 & 850 & 4.8 & 6.7 \\ 1021 & 3.34 & 0.147 & 750 & 4.5 & 6.2 \\ 1022 & 6.95 & 0.142 & 540 & 4.0 & 5.1 \\ 1023 & 12.8 & 0.133 & 380 & 3.5 & 4.0 \\ 1024 & 18.4 & 0.125 & 260 & 4.0 & 3.8\end{array}$

$G=150$

$\begin{array}{lllrrr}1000 & 0.114 & 0.61 & 3150 & 13.4 & 23.3 \\ 1001 & 0.178 & 0.61 & 2900 & 12.6 & 21.3 \\ 1002 & 0.271 & 0.61 & 2610 & 11.5 & 19.5 \\ 1003 & 0.349 & 0.61 & 2430 & 10.8 & 18.6 \\ 1004 & 0.619 & 0.61 & 2000 & 9.5 & 15.3 \\ 1005 & 1.02 & 0.61 & 1600 & 8.3 & 12.8 \\ 1006 & 1.42 & 0.61 & 1430 & 8.0 & 11.9 \\ 1007 & 1.92 & 0.61 & 1240 & 7.8 & 11.5 \\ 1008 & 3.05 & 0.605 & 1010 & 7.5 & 11.2 \\ 1009 & 5.95 & 0.60 & 770 & 8.5 & 11.5 \\ 1010 & 10.3 & 0.595 & 570 & 9.5 & 11.7 \\ 1011 & 14.5 & 0.590 & 470 & 10.7 & 11.9 \\ 1012 & 19.0 & 0.585 & 450 & 12.0 & 12.6\end{array}$


APPENDIX B

Holdup and Pressure Drop Reproducibility Data

Run No.
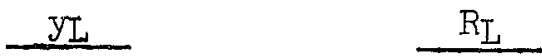

$\triangle \mathrm{P}, \mathrm{In}$. Hg.

Air-Water Funs

$$
G=25
$$

248

251

0.378

0.58

9.95

0.378

0.585

9.85

256

0.378

0.59

0.378

0.592

9.95

259

0.378

9.85

262

0.053

0.58

249

0.053

0.265

9.85

255

0.053

0.248

4.65

258

0.053

0.261

4.35

260

0.053

0.248

4.35

266

0.0042

0.265

4.0

245

0.0042

0.0785

4.35

250

0.0042

0.0826

3.7

257

0.0042

0.0775

261

0.0042

0.087

0.0785

Air-Water Runs

$$
G=50
$$
269
275
0.378
0.51
8.8
281
0.378
0.495
8.6
288
0.378
0.51
8.6
296
0.378
0.511
8.8
0.378
0.499
8.5

Air-Sodium Carbonate Solution Puns

$$
G=25
$$

$\begin{array}{ll}346 & 0.378 \\ 405 & 0.378 \\ 408 & 0.378 \\ 424 & 0.378 \\ 430 & 0.378\end{array}$

0.664

0.627

12.65

0.635

12.4

0.609

11.85

11.75

11.65 
Holdup and Pressure Drop Reproducibility Data

(Continued)

Run No.

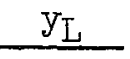

$\mathrm{R}_{\mathrm{L}}$

$\triangle \mathrm{P}$, In. $\mathrm{Hg}$.

Air-Varsol Runs

$$
G=25
$$

$\begin{array}{ll}588 & 0.378 \\ 591 & 0.378 \\ 610 & 0.378 \\ 613 & 0.378 \\ 616 & 0.378\end{array}$

0.511

6.95

0.532

7.1

7.2

7.1

0.539

0.518

7.0

Air-Oil Blend No. I Runs

$$
G=25
$$

$\begin{array}{llll}805 & 0.378 & 0.58 & 7.9 \\ 808 & 0.378 & 0.56 & 7.8 \\ 811 & 0.378 & 0.565 & 7.7 \\ 814 & 0.378 & 0.565 & 7.9 \\ 817 & 0.378 & 0.558 & 7.8\end{array}$

Air-Oil Blend No. 2 Runs

$$
G=25
$$

$\begin{array}{llll}957 & 0.363 & 0.73 & 10.05 \\ 958 & 0.363 & 0.725 & 10.2 \\ 959 & 0.363 & 0.734 & 10.05 \\ 960 & 0.363 & 0.729 & 10.05 \\ 961 & 0.363 & 0.711 & 10.05\end{array}$

Air-Trichloroethylene Runs

$\mathrm{G}=37.5$

$\begin{array}{llll}1025 & 0.378 & 0.53 & 19.0 \\ 1026 & 0.378 & 0.525 & 18.0 \\ 1027 & 0.378 & 0.525 & 18.0 \\ 1028 & 0.378 & 0.521 & 18.0 \\ 1029 & 0.378 & 0.515 & 18.2\end{array}$


APPENDTX $\mathrm{C}$

Summary of Calculated Values

Run No.

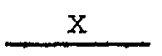

Holdup

Slip Velocity

Pressure Drop

$\mathrm{Ib} / \mathrm{Sq}$ Ft Per

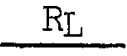
$\mathrm{Ft} / \mathrm{Sec}$. Ft of Pipe $\triangle \mathrm{PTP} / \mathrm{I}$

Air-Water Runs

$$
G=5
$$

135
136
137
138
139
140
141
142
143
144
145
146
147
148
149
150
151
152
153
194
195
196
197
198

$\begin{array}{ll}0.054 & 0.23 \\ 0.039 & 0.209 \\ 0.028 & 0.179 \\ 0.0225 & 0.168 \\ 0.018 & 0.146 \\ 86.5 & 0.985 \\ 5.7 & 0.90 \\ 2.63 & 0.82 \\ 1.22 & 0.69 \\ 0.76 & 0.60 \\ 0.54 & 0.515 \\ 0.43 & 0.468 \\ 0.42 & 0.46 \\ 0.31 & 0.377 \\ 0.22 & 0.301 \\ 0.14 & 0.251 \\ 0.097 & 0.232 \\ 0.08 & 0.234 \\ 0.05 & 0.23 \\ 0.034 & 0.190 \\ 0.019 & 0.147 \\ 0.0118 & 0.104 \\ 0.0068 & 0.065 \\ 0.0056 & 0.0405\end{array}$

10.6

13.0

14.4

12.5

17.7

11.0

21.2

24.6

10.5

9.5

0.42

5.0

140

142

143

144

145

146

147

148

0.45

19.5

0.63

0.87

27.2

1.15

1.36

27.2

26.0

1.66

22.3

19.2

1.67

1.94

2.67

4.1

5.82

6.83

7.8

15.9

24.0

31.9

48.1

56.0

21.0

16.0

12.5

10.2

10.2

11.2

12.0

10.7

10.0

7.0

5.2

3.7

$G=10$

$\begin{array}{lll}54 & 0.367 & 0.312 \\ 55 & 0.273 & 0.297 \\ 56 & 0.19 & 0.255 \\ 57 & 0.147 & 0.249 \\ 58 & 0.119 & 0.234 \\ 59 & 0.101 & 0.231 \\ 60 & 0.08 & 0.224\end{array}$

2.0

12.0

2.9

3.95

10.5

10.0

5.6

6.7

10.2

10.5

8.7

11.5

11.4

13.7 
Summary of Calculated Values

(Continued)

\begin{tabular}{|c|c|c|c|c|}
\hline Run No. & $\mathrm{x}$ & $\begin{array}{c}\text { Holdup } \\
\text { RL } \\
\end{array}$ & $\begin{array}{c}\text { Slip Velocity } \\
\text { Ft/Sec. } \\
V_{S} \\
\end{array}$ & $\begin{array}{r}\text { Pressure } \\
\mathrm{Lb} / \mathrm{Sq} \mathrm{Ft} \\
\mathrm{Ft} \text { of } \mathrm{Pi} \\
\triangle \mathrm{PrP} / \mathrm{I} \\
\end{array}$ \\
\hline \multicolumn{5}{|c|}{ Air-water Runs (Continued) } \\
\hline 61 & 0.065 & 0.227 & 14.7 & 13.7 \\
\hline 78 & 119.0 & 0.985 & 0.33 & 3.0 \\
\hline 79 & 14.5 & 0.941 & 0.50 & 6.2 \\
\hline 80 & 5.8 & 0.889 & 0.61 & 16.0 \\
\hline 81 & 3.6 & 0.843 & 0.64 & 18.7 \\
\hline 82 & 1.7 & 0.737 & 0.93 & 23.0 \\
\hline 83 & 1.05 & 0.633 & 1.15 & 22.2 \\
\hline 84 & 0.77 & 0.57 & 1.43 & 20.5 \\
\hline 85 & 0.62 & 0.49 & $1 . 5 \longdiv { 4 }$ & 19.0 \\
\hline 187 & 0.053 & 0.205 & 15.9 & 10.0 \\
\hline 188 & 0.033 & 0.16 & 23.6 & 8.2 \\
\hline 189 & 0.0227 & 0.118 & 32.1 & 6.7 \\
\hline 190 & 0.0163 & 0.090 & 40.3 & 5.0 \\
\hline 191 & 0.0124 & 0.067 & 46.7 & 4.5 \\
\hline 192 & 0.009 & 0.048 & 56.7 & 4.0 \\
\hline 193 & 0.0064 & 0.039 & 66.4 & 4.5 \\
\hline 224 & 0.415 & 0.415 & 1.6 & 15.5 \\
\hline 225 & 0.352 & 0.352 & 2.15 & 17.5 \\
\hline 226 & 0.289 & 0.289 & 3.0 & 10.7 \\
\hline 227 & 0.266 & 0.266 & 3.95 & 10.7 \\
\hline 228 & 0.232 & 0.232 & 4.8 & 10.5 \\
\hline 229 & 0.235 & 0.235 & 5.8 & 10.7 \\
\hline 230 & 0.232 & 0.232 & 7.4 & 10.0 \\
\hline 278 & 0.0048 & 0.035 & 74.6 & 4.0 \\
\hline 279 & 0.0031 & 0.028 & 85.1 & 4.0 \\
\hline 280 & 0.0016 & 0.020 & 99.4 & 4.0 \\
\hline
\end{tabular}

$$
G=25
$$

$\begin{array}{rcl}33 & 0.418 & 0.349 \\ 34 & 0.225 & 0.266 \\ 35 & 0.16 & 0.277 \\ 36 & 0.125 & 0.255 \\ 37 & 0.103 & 0.241 \\ 86 & 12.1 & 0.985 \\ 87 & 5.5 & 0.938 \\ 88 & 2.6 & 0.878 \\ 89 & 2.6 & 0.78 \\ 90 & 1.62 & 0.692 \\ 91 & 1.18 & 0.605 \\ 92 & 0.95 & 0.555 \\ 158 & 0.74 & 0.532 \\ 180 & 0.087 & 0.232 \\ 181 & 0.059 & 0.204\end{array}$

$\begin{array}{lr}2.36 & 10.2 \\ 4.8 & 10.5 \\ 8.66 & 13.0 \\ 10.7 & 15.5 \\ 13.4 & 15.2 \\ 0.57 & 2.2 \\ 0.45 & 4.2 \\ 0.6 & 7.5 \\ 0.81 & 12.2 \\ 1.07 & 14.7 \\ 1.18 & 15.0 \\ 1.38 & 14.2 \\ 1.65 & 15.0 \\ 14.75 & 15.5 \\ 23.7 & 14.2\end{array}$


Summary of Calculated Values

(Continued)

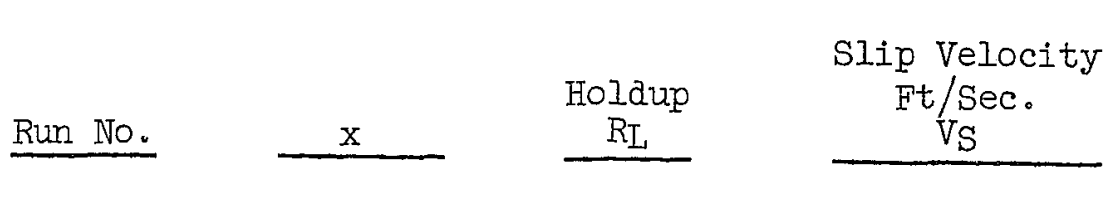

Pressure Drop

Lb/Sq Ft Per

Ft of Pipe

$\triangle \mathrm{P}_{\mathrm{TP}} / \mathrm{I}$

\section{Air-Water Runs (Continued)}

$\begin{array}{lll}182 & 0.042 & 0.167 \\ 183 & 0.032 & 0.143 \\ 184 & 0.026 & 0.116 \\ 185 & 0.0211 & 0.10 \\ 186 & 0.0175 & 0.087 \\ 218 & 0.56 & 0.42 \\ 219 & 0.407 & 0.342 \\ 220 & 0.31 & 0.315 \\ 221 & 0.246 & 0.286 \\ 222 & 0.212 & 0.268 \\ 223 & 0.175 & 0.258 \\ 245 & 0.0151 & 0.0785 \\ 246 & 0.0127 & 0.066 \\ 247 & 0.010 & 0.056\end{array}$

31.4

39.6

47.5

56.0

65.5

1.85

2.5

3.5

4.4

5.5

6.8

74.5

82.5

95.4

13.2

13.0

13.0

12.5

12.5

12.0

10.5

10.7

10.5

16.7

12.5

12.2

12.2

13.5

$$
G=50
$$

$\begin{array}{rlllr}27 & 0.595 & 0.41 & 1.75 & 9.0 \\ 28 & 0.318 & 0.336 & 4.35 & 10.5 \\ 29 & 0.22 & 0.306 & 7.5 & 13.5 \\ 30 & 0.174 & 0.289 & 9.5 & 15.5 \\ 31 & 0.144 & 0.278 & 12.3 & 16.7 \\ 47 & 0.595 & 0.415 & 1.8 & 8.2 \\ 99 & 80.0 & 0.985 & 0.2 & 1.0 \\ 100 & 16.9 & 0.948 & 0.2 & 1.7 \\ 101 & 7.7 & 0.90 & 0.4 & 3.5 \\ 102 & 3.74 & 0.827 & 0.7 & 6.2 \\ 103 & 2.3 & 0.74 & 0.8 & 8.0 \\ 104 & 1.67 & 0.693 & 1.1 & 9.5 \\ 105 & 1.34 & 0.643 & 1.65 & 11.2 \\ 120 & 0.194 & 0.303 & 1.85 & 21.7 \\ 121 & 0.145 & 0.286 & 12.6 & 20.7 \\ 122 & 0.115 & 0.261 & 16.6 & 21.0 \\ 123 & 0.098 & 0.238 & 19.7 & 21.0 \\ 124 & 0.085 & 0.24 & 23.8 & 20.2 \\ 157 & 1.12 & 0.607 & 1.45 & 9.7 \\ 173 & 0.126 & 0.248 & 13.3 & 18.5 \\ 174 & 0.084 & 0.232 & 22.2 & 18.7 \\ 175 & 0.052 & 0.196 & 29.9 & 18.2 \\ 176 & 0.05 & 0.175 & 36.9 & 18.5 \\ 177 & 0.040 & 0.16 & 45.6 & 19.5 \\ 178 & 0.0335 & 0.151 & 54.7 & 21.0 \\ 179 & 0.0282 & 0.136 & 63.3 & 19.2 \\ 212 & 0.82 & 0.503 & 1.6 & 10.0 \\ & & & & \end{array}$




\begin{tabular}{|c|c|c|c|c|}
\hline Run No. & $x$ & $\begin{array}{c}\text { Holdup } \\
\mathrm{R}_{\mathrm{L}} \\
\end{array}$ & $\begin{array}{c}\text { Slip Velocity } \\
V_{S} \\
\end{array}$ & $\begin{array}{c}\text { Pressure Drop } \\
\text { Lb/Sq Ft Per } \\
\text { Ft of Pipe } \\
\triangle \mathrm{PTP}_{\mathrm{TP}}\end{array}$ \\
\hline \multicolumn{5}{|c|}{ Air-Water Runs (Continued) } \\
\hline 213 & 0.59 & 0.41 & 2.0 & 9.7 \\
\hline 214 & 0.443 & 0.36 & 2.7 & 10.7 \\
\hline 215 & 0.36 & 0.36 & 4.0 & 11.0 \\
\hline 216 & 0.305 & 0.311 & 4.4 & 12.5 \\
\hline 217 & 0.23 & 0.311 & 6.7 & 13.5 \\
\hline 252 & 0.025 & 0.126 & 70.3 & 20.5 \\
\hline 253 & 0.0211 & 0.115 & 78.3 & 21.7 \\
\hline 254 & 0.0185 & 0.110 & 91.5 & 22.7 \\
\hline
\end{tabular}

$G=100$

\begin{tabular}{|c|c|c|c|c|}
\hline 93 & 56.5 & 0.964 & & 1.0 \\
\hline 94 & 16.8 & 0.935 & 0.25 & 2.5 \\
\hline 95 & 7.05 & 0.878 & 0.55 & 3.2 \\
\hline 96 & 4.15 & 0.831 & 0.96 & 5.7 \\
\hline 97 & 3.2 & 0.788 & 1.24 & 6.2 \\
\hline 98 & 2.4 & 0.738 & 1.26 & 7.0 \\
\hline 115 & 0.376 & 0.35 & 6.5 & 18.5 \\
\hline 116 & 0.278 & 0.311 & 9.6 & 21.7 \\
\hline 117 & 0.228 & 0.296 & 12.9 & 23.2 \\
\hline 118 & 0.19 & 0.272 & 15.5 & 24.5 \\
\hline 119 & 0.166 & 0.259 & 18.6 & 26.0 \\
\hline 156 & 2.2 & 0.71 & 1.28 & 7.5 \\
\hline 166 & 0.248 & 0.312 & 11.9 & 22.5 \\
\hline 167 & 0.172 & 0.269 & 18.6 & 26.7 \\
\hline 168 & 0.125 & 0.24 & 26.2 & 29.0 \\
\hline 169 & 0.10 & 0.221 & 33.2 & 30.7 \\
\hline 170 & 0.083 & 0.202 & 40.6 & 32.5 \\
\hline 171 & 0.070 & 0.19 & 48.0 & 34.7 \\
\hline 172 & 0.060 & 0.182 & 55.7 & 35.7 \\
\hline 206 & 1.56 & 0.63 & 1.7 & 7.5 \\
\hline 207 & 1.12 & 0.53 & 1.7 & 9.2 \\
\hline 208 & 0.86 & 0.47 & 2.2 & 11.5 \\
\hline 209 & 0.70 & 0.443 & 3.2 & 12.7 \\
\hline 210 & 0.60 & $0.4 I$ & 3.9 & 13.7 \\
\hline 211 & 0.455 & 0.363 & 5.2 & 17.2 \\
\hline 263 & 0.054 & 0.16 & 61.8 & 37.2 \\
\hline 264 & 0.048 & 0.154 & 68.5 & 38.2 \\
\hline 265 & 0.042 & 0.147 & 77.8 & 39.0 \\
\hline \multicolumn{5}{|c|}{$G=150$} \\
\hline 40 & 3.4 & 0.77 & 1.15 & 6.7 \\
\hline 41 & 1.78 & 0.65 & 2.5 & 9.7 \\
\hline
\end{tabular}


Run No.

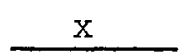

Holdup

Air-Water Runs (Continued)

$\begin{array}{lll}42 & 0.92 & 0.489 \\ 43 & 0.65 & 0.43 \\ 44 & 0.51 & 0.381 \\ 62 & 2.3 & 0.692 \\ 63 & 1.22 & 0.565 \\ 64 & 0.77 & 0.455 \\ 72 & 82.5 & 0.972 \\ 73 & 21.0 & 0.955 \\ 74 & 10.2 & 0.913 \\ 75 & 6.4 & 0.876 \\ 76 & 4.75 & 0.832 \\ 77 & 3.75 & 0.80 \\ 106 & 0.57 & 0.42 \\ 107 & 0.43 & 0.378 \\ 108 & 0.35 & 0.333 \\ 109 & 0.29 & 0.314 \\ 110 & 0.26 & 0.31 \\ 155 & 4.0 & 0.77 \\ 159 & 0.38 & 0.332 \\ 160 & 0.255 & 0.297 \\ 161 & 0.192 & 0.272 \\ 162 & 0.163 & 0.249 \\ 163 & 0.132 & 0.235 \\ 164 & 0.111 & 0.218 \\ 165 & 0.098 & 0.199 \\ 200 & 2.32 & 0.702 \\ 201 & 1.67 & 0.63 \\ 202 & 1.29 & 0.58 \\ 203 & 1.05 & 0.521 \\ 204 & 0.89 & 0.485 \\ 205 & 0.665 & 0.425 \\ 272 & 0.087 & 0.196 \\ 273 & 0.078 & 0.181 \\ 274 & 0.068 & 0.168 \\ & & \end{array}$

Pressure Drop $\mathrm{Lb} / \mathrm{Sq}$ Ft Per Ft of Pipe $\triangle \mathrm{PTP} / \mathrm{L}$

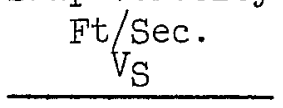

3.0

15.2

4.9

6.35

1.4

2.85

4.0

18.0

21:.2

9.0

12.5

14.7

0.4

0.55

2.2

3.0

1.0

4.0

1.0

5.0

1.2

6.6

6.0

6.2

9.1

21:2

10.6

25.0

27.5

13.9

17.1

31.5

33.0

1.2

11.7

28.2

34.7

5.0

$15 \cdot 9$

28.4

38.2

40.7

34.3

40.9

45.9

1.45

1.85

2.63

2.9

3.36

4.3

45.0

47.0

51.0

6.5

9.5

11.7

16.2

15.0

17.5

53.3

58.9

53.2

55.2

67.1 
Summary of Calculated Values

(Continued)

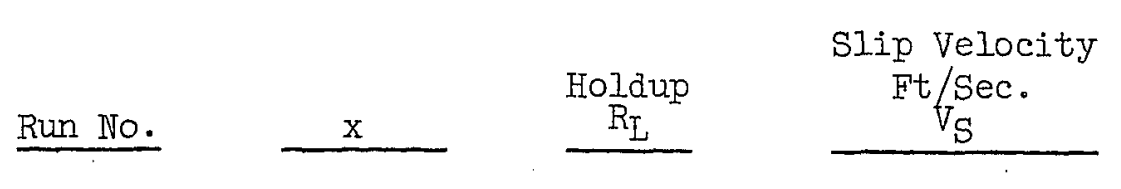

Pressure Drop $\mathrm{Lb} / \mathrm{Sq}$ Ft Per Ft of Pipe $\triangle \mathrm{P} T \mathrm{TP} / \mathrm{L}$

Air-Sodium Carbonate Solution Runs

$$
G=5
$$

$\begin{array}{lllll}371 & 12.1 & 0.958 & 0.56 & 17.7 \\ 372 & 3.1 & 0.844 & 0.70 & 35.0 \\ 373 & 1.18 & 0.605 & 0.80 & 27.2 \\ 374 & 0.78 & 0.483 & 0.99 & 23.5 \\ 375 & 0.53 & 0.39 & 1.31 & 20.0 \\ 376 & 0.42 & 0.377 & 1.68 & 17.5 \\ 377 & 0.246 & 0.312 & 2.76 & 14.2 \\ 378 & 0.157 & 0.266 & 4.28 & 12.0 \\ 379 & 0.114 & 0.256 & 5.93 & 11.7 \\ 380 & 0.092 & 0.235 & 6.85 & 12.0 \\ 381 & 0.082 & 0.228 & 7.85 & 11.2 \\ 382 & 0.0445 & 0.215 & 12.1 & 12.2 \\ 383 & 0.0284 & 0.175 & 19.8 & 11.2 \\ 384 & 0.0128 & 0.127 & 32.9 & 8.0 \\ 402 & 0.056 & 0.102 & 41.6 & 7.0 \\ 403 & 0.0305 & 0.073 & 49.0 & 5.2 \\ 404 & 0.0215 & 0.0615 & 53.2 & 3.7\end{array}$

$$
G=10
$$

$\begin{array}{lllll}357 & 16.5 & 0.965 & 0.64 & 12.0 \\ 358 & 4.3 & 0.852 & 0.66 & 23.7 \\ 359 & 1.63 & 0.638 & 0.80 & 22.2 \\ 360 & 1.09 & 0.55 & 1.02 & 24.5 \\ 361 & 0.74 & 0.443 & 1.27 & 17.2 \\ 362 & 0.60 & 0.423 & 1.63 & 17.5 \\ 363 & 0.35 & 0.317 & 2.53 & 12.7 \\ 364 & 0.227 & 0.283 & 4.1 & 12.0 \\ 365 & 0.166 & 0.249 & 5.5 & 11.7 \\ 366 & 0.135 & 0.263 & 6.8 & 12.0 \\ 367 & 0.123 & 0.255 & 7.9 & 12.0 \\ 368 & 0.080 & 0.23 & 12.0 & 13.7 \\ 369 & 0.048 & 0.192 & 19.4 & 12.7 \\ 370 & 0.0264 & 0.143 & 33.0 & 10.0 \\ 395 & 0.0264 & 0.147 & 32.3 & 10.2 \\ 396 & 0.0184 & 0.118 & 41.7 & 8.2 \\ 397 & 0.014 & 0.094 & 49.4 & 7.5 \\ 398 & 0.0107 & 0.0785 & 57.4 & 7.5 \\ 399 & 0.0076 & 0.0675 & 69.1 & 6.2 \\ 400 & 0.0056 & 0.0575 & 77.6 & 6.7 \\ 401 & 0.0024 & 0.0475 & 95.9 & 6.7\end{array}$


Summary of Calculated Values

(Continued)

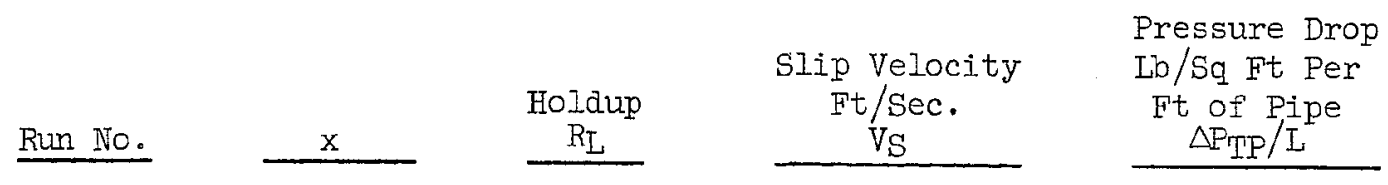

Air-Sodium Carbonate Solution Runs (Continued)

$G=25$

$\begin{array}{lllll}343 & 25.4 & 0.97 & 0.55 & 6.5 \\ 344 & 6.6 & 0.885 & 0.65 & 10.5 \\ 345 & 2.44 & 0.725 & 0.80 & 16.0 \\ 346 & 1.64 & 0.628 & 1.0 & 16.5 \\ 347 & 1.15 & 0.545 & 1.2 & 15.5 \\ 348 & 0.93 & 0.50 & 1.5 & 15.0 \\ 349 & 0.57 & 0.395 & 2.3 & 13.2 \\ 350 & 0.35 & 0.348 & 3.9 & 12.2 \\ 351 & 0.266 & 0.301 & 5.25 & 13.5 \\ 352 & 0.216 & 0.289 & 6.2 & 13.0 \\ 353 & 0.201 & 0.27 & 7.0 & 13.0 \\ 354 & 0.129 & 0.227 & 10.8 & 16.5 \\ 355 & 0.0785 & 0.221 & 19.0 & 15.5 \\ 356 & 0.047 & 0.168 & 31.1 & 13.5 \\ 391 & 0.037 & 0.148 & 39.4 & 13.2 \\ 392 & 0.030 & 0.126 & 46.8 & 12.2 \\ 393 & 0.024 & 0.109 & 55.3 & 13.2 \\ 394 & 0.020 & 0.098 & 66.4 & 12.5 \\ 417 & 0.0166 & 0.085 & 73.8 & 13.2 \\ 418 & 0.0132 & 0.071 & 88.3 & 14.2\end{array}$

$$
G=50
$$

$\begin{array}{llllr}329 & 35.2 & 0.978 & 0.1 & 1.5 \\ 330 & 9.2 & 0.915 & 0.45 & 4.5 \\ 331 & 3.55 & 0.795 & 0.7 & 10.0 \\ 332 & 2.38 & 0.712 & 0.8 & 11.7 \\ 333 & 1.66 & 0.63 & 1.1 & 10.7 \\ 334 & 1.32 & 0.60 & 1.3 & 11.7 \\ 335 & 0.79 & 0.481 & 2.1 & 12.0 \\ 336 & 0.52 & 0.384 & 3.0 & 11.5 \\ 337 & 0.38 & 0.335 & 4.2 & 15.2 \\ 338 & 0.31 & 0.307 & 5.0 & 14.7 \\ 339 & 0.284 & 0.303 & 6.0 & 15.2 \\ 340 & 0.189 & 0.284 & 10.4 & 19.2 \\ 341 & 0.116 & 0.225 & 16.7 & 21.0 \\ 342 & 0.070 & 0.204 & 28.1 & 18.7 \\ 389 & 0.046 & 0.155 & 43.5 & 19.7 \\ 390 & 0.032 & 0.134 & 61.9 & 21.2 \\ 415 & 0.0266 & 0.118 & 73.7 & 22.7 \\ 416 & 0.0226 & 0.101 & 81.7 & 23.7\end{array}$


Run No.

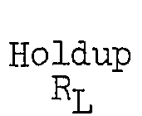

Slip Velocity $\mathrm{Ft} / \mathrm{Sec}$.

$\mathrm{V}_{\mathrm{S}}$.
Pressure Drop $\mathrm{Lb} / \mathrm{Sq} \mathrm{Ft}$ Per Ft of Pipe $\triangle \mathrm{PTP} / \mathrm{L}$

Air-Sodium Carbonate Solution Runs (Continued)

$$
G=100
$$

$\begin{array}{lll}316 & 16.8 & 0.948 \\ 317 & 6.8 & 0.86 \\ 318 & 4.6 & 0.801 \\ 319 & 3.2 & 0.73 \\ 320 & 2.62 & 0.70 \\ 321 & 1.56 & 0.59 \\ 322 & 1.23 & 0.575 \\ 323 & 0.74 & 0.43 \\ 324 & 0.61 & 0.406 \\ 325 & 0.55 & 0.367 \\ 326 & 0.51 & 0.367 \\ 327 & 0.225 & 0.272 \\ 328 & 0.14 & 0.213 \\ 387 & 0.092 & 0.182 \\ 388 & 0.068 & 0.171 \\ 413 & 0.055 & 0.153 \\ 414 & 0.049 & 0.144\end{array}$

0.9

0.8

0.9

1.0

1.4

2.2

4.5

3.8

4.6

4.8

5.7

15.0

24.8

38.1

56.3

64.4

74.5
3.0

5.0

5.7

4.0

8.0

10.5

17.0

15.2

16.7

17.2

18.2

26.7

30.0

31.0

34.7

35.0

39.2

$$
G=150
$$

$\begin{array}{lll}300 & 97.0 & 0.98 \\ 301 & 23.5 & 0.966 \\ 302 & 12.3 & 0.935 \\ 303 & 7.5 & 0.871 \\ 304 & 6.85 & 0.84 \\ 305 & 4.7 & 0.793 \\ 306 & 3.9 & 0.767 \\ 307 & 2.3 & 0.666 \\ 308 & 1.5 & 0.579 \\ 309 & 1.1 & 0.497 \\ 310 & 0.89 & 0.462 \\ 311 & 0.83 & 0.435 \\ 312 & 0.77 & 0.433 \\ 313 & 0.344 & 0.311 \\ 314 & 0.218 & 0.27 \\ 385 & 0.146 & 0.225 \\ 386 & 0.108 & 0.186 \\ 411 & 0.091 & 0.180 \\ 412 & 0.079 & 0.160\end{array}$

-
1.9
0.9
1.2
1.1
1.5
2.2
3.0
3.6
4.2
4.7
5.5
13.5
23.5
37.2
48.1
58.0
64.8

53.0 
Summary of Calculated Values (Continued)

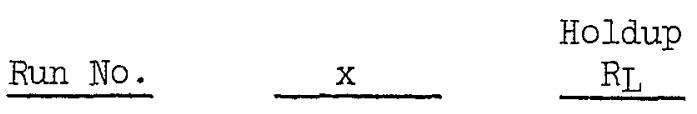

Slip Velocity

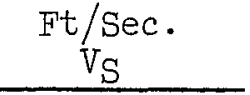

Pressure Drop $\mathrm{Lb} / \mathrm{Sq} \mathrm{Ft}$ Per Ft of Pipe $\triangle \mathrm{PTP} / \mathrm{I}$

Air-Varsol Runs

$$
G=5
$$

594
595
596
597
598
599
600
601
602
603
604
605
606
607
608
609

9.8

2.52

0.95

0.64

0.433

0.368

0.209

0.134

0.098

0.08

0.073

0.046

0.025

0.0118

0.005

0.0044

$\mathrm{G}=10$
570

571

572

573

574

575

576

577

578

579

580

581

582

583

584

585

586

587

$$
13.4
$$

3.5

1.31

0.89

0.61

0.49

0.29

0.188

0.14

0.115

0.104

0.069

0.039

0.022

0.0143

0.0094

0.00495

0.00155
0.941

0.803

0.485

0.43

0.35

0.295

0.285

0.25

0.278

0.254

0.258

0.225

0.168

0.103

0.064

0.061
0.4

0.55

0.57

0.88

1.2

1.4

2.7

4.2

6.14

7.11

8.35

12.5

20.1

32.0

$4 ! .5$

46.5
8.2

16.0

14.0

11.2

9.2

7.5

7.0

7.5

8.2

8.2

8.7

8.7

6.7

3.7

2.5

2.5

$$
G=25
$$

516

517
20.6

5.35
0.94

0.84

0.591

0.46

0.392

0.356

0.311

0.283

0.292

0.286

0.28

0.241

0.188

0.132

0.090

0.070

0.052

0.039
0.28

0.61

0.63

0.71

1. 04

1.32

2.5

4.0

6.0

7.1

8.1

12.3

20.2

31.9

43.6

57.4

77.6

103.3
4.2

7.0

10.7

9.5

7.7

7.5

6.2

7.5

8.2

8.2

9.7

9.0

7.5

5.7

4.7

4.5

4.5

4.5

0.985

1.4

0.9

1.7

5.5 
Run No.

Holdup

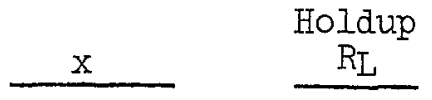

Slip Velocity

Pressure Drop $\mathrm{Lb} / \mathrm{Sq}$ Ft Per

Air-Varsol Runs (Continued)

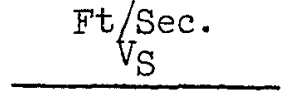

Ft of Pipe $\triangle \mathrm{PTP} / \mathrm{I}$

$\begin{array}{llllr}518 & 2.08 & 0.72 & 0.7 & 7.2 \\ 519 & 1.38 & 0.585 & 0.1 & 6.5 \\ 520 & 0.97 & 0.51 & 0.88 & 5.5 \\ 521 & 0.78 & 0.46 & 1.0 & 6.7 \\ 522 & 0.475 & 0.353 & 1.8 & 6.0 \\ 523 & 0.305 & 0.311 & 3.0 & 6.2 \\ 524 & 0.23 & 0.28 & 4.6 & 7.5 \\ 525 & 0.187 & 0.299 & 6.1 & 9.0 \\ 526 & 0.172 & 0.272 & 6.8 & 9.7 \\ 527 & 0.158 & 0.264 & 7.1 & 10.0 \\ 528 & 0.068 & 0.202 & 18.5 & 9.2 \\ 529 & 0.041 & 0.151 & 30.0 & 8.7 \\ 530 & 0.028 & 0.126 & 43.2 & 9.0 \\ 531 & 0.0206 & 0.115 & 57.4 & 9.5 \\ 532 & 0.0148 & 0.087 & 73.6 & 10.0 \\ 533 & 0.0103 & 0.070 & 95.2 & 10.7\end{array}$

$G=50$

534

535

536

537

538

539

540

541

542

543

544

545

546

547

548

549

550

$G=100$
$7 \cdot 2$

6.5

5.5

6.7

6.0

6.2

7.5

9.0

9.7

9.2

8.7

9.0

9.5

10.7
500

501

502

503

504

505
7.4

2.94

1.95

1.35

1.1

0.66

0.43

0.32

0.26

0.243

0.16

0.099

0.0603

0.0435

0.0325

0.0245

0.0185
0.945

0.815

0.723

0.617

0.575

0.448

0.37

0.345

0.32

0.308

0.266

0.218

0.174

0.148

0.131

0.112

0.106
1.3

0.8

0.7

0.75

0.8

1.4

2.1

3.9

5.6

9.3

16.2

26.4

38.6

52.3

64.5

88.0

$\begin{array}{ll}5.55 & 0.876 \\ 3.7 & 0.795 \\ 2.6 & 0.75 \\ 2.1 & 0.71 \\ 1.27 & 0.641 \\ 0.83 & 0.508\end{array}$

0.6

0.2

0.7

0.8

2.1

1.8

3.0

4.5

4.5

5.0

5.0

7.2

6.2

7.5

8.5

9.5

11.7

13.0

13.2

14.2

15.7

16.7

18.2 
Summary of Calculated Values

(Continued)

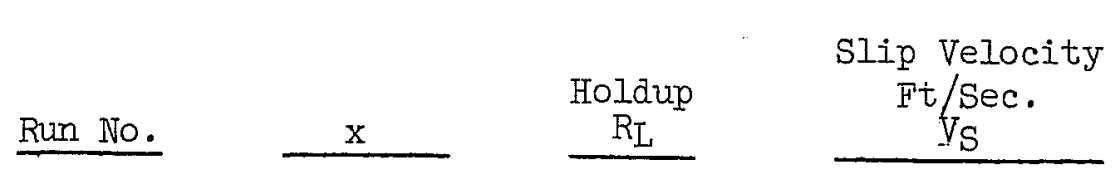

Pressure Drop $\mathrm{Lb} / \mathrm{Sq}$ Ft Per Ft of Pipe $\triangle P_{T P} / I$

Air-Varsol Runs (Continuea)

$\begin{array}{lllrr}506 & 0.61 & 0.447 & 3.1 & 8.0 \\ 507 & 0.51 & 0.41 & 3.5 & 8.2 \\ 508 & 0.475 & 0.389 & 4.2 & 9.7 \\ 509 & 0.445 & 0.375 & 4.4 & 8.2 \\ 510 & 0.192 & 0.255 & 12.5 & 16.5 \\ 511 & 0.122 & 0.211 & 19.0 & 18.7 \\ 512 & 0.09 & 0.188 & 32.5 & 24.0 \\ 513 & 0.07 & 0.166 & 42.4 & 26.0 \\ 514 & 0.054 & 0.153 & 58.5 & 28.0 \\ 515 & 0.042 & 0.133 & 72.5 & 30.7\end{array}$

$G=150$

$\begin{array}{lll}554 & 8.25 & 0.878 \\ 555 & 5.5 & 0.855 \\ 556 & 3.8 & 0.807 \\ 557 & 3.2 & 0.772 \\ 558 & 1.91 & 0.667 \\ 559 & 1.28 & 0.583 \\ 560 & 0.94 & 0.513 \\ 561 & 0.78 & 0.49 \\ 562 & 0.71 & 0.468 \\ 563 & 0.47 & 0.39 \\ 564 & 0.25 & 0.286 \\ 565 & 0.173 & 0.235 \\ 566 & 0.122 & 0.199\end{array}$

0.1

2.7

4.5

0.4

4.7

0.6

6.2

0.9

6.5

1.2

7.7

2.1

2.9

9.7

3.6

6.1

12.5

19.7

31.8

11.0

12.5

15.7

24.5

30.2

34.2 
Summary of Calculated Values (Continued)

$\underline{\text { Run INo. }}$

Holdup

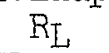

Slip Velocity Ft/Sec.

$\mathrm{VS}$
Pressure Drop $\mathrm{Lb} / \mathrm{Sq}$ Ft Per Ft of Pipe $\triangle \mathrm{PTP} / \mathrm{I}$

Air-0il Blend No. I Runs

$$
G=5
$$

$\begin{array}{lll}785 & 13.2 & 0.958 \\ 786 & 3.37 & 0.795 \\ 787 & 1.29 & 0.577 \\ 788 & 0.87 & 0.482 \\ 789 & 0.605 & 0.423 \\ 790 & 0.48 & 0.409 \\ 791 & 0.283 & 0.358 \\ 792 & 0.193 & 0.322 \\ 793 & 0.132 & 0.28 \\ 794 & 0.097 & 0.272 \\ 795 & 0.060 & 0.235 \\ 796 & 0.025 & 0.173 \\ 797 & 0.0119 & 0.118 \\ 798 & 0.0068 & 0.098 \\ 799 & 0.00285 & 0.0755 \\ 800 & 0.0012 & 0.056\end{array}$

0.6

0.55

0.77

1.0

1.4

1.8

3.29

4.42

6.5

8.9

13.1

25.4

37.1

45.5

54.7

59.0
9.5

18.2

16.0

13.7

12.2

12.2

11.2

9.5

9.2

9.5

9.0

7.2

5.0

5.0

4,2

3.5

$G=10$

766
767
768
769
770
771
772
773
774
775
776
777
778
779
780
781

18.4

$\begin{array}{ll}767 & 4.65 \\ 768 & 1.84\end{array}$

0.965

0.6

5.2

0.84

0.6

11.7

1.2

0.625

0.7

12.7

0.84

0.532

0.9

11.7

0.74

0.465

1.3

10.5

0.4

1.5

0.373

2.8

10.7

0.277

0.334

10.5

0.194

0.300

4.2

6.0

10.2

0.144

0.269

8.0

0.094

0.224

0.045

0.193

0.022

0.140

0.0122

0.103

0.0062

0.073

0.0021

0.0475

11.9

24.6

42.3

60.0

79.1

101.5

9.2

9.7

10.0

9.0

6.7

7.0

7.5

8.0

$$
G=25
$$

715
716
717
718

$\begin{array}{ll}7.0 & 0.905 \\ 2.8 & 0.76 \\ 1.89 & 0.667 \\ 1.31 & 0.589\end{array}$

0.9

0.9

6.5

8.2

1.1

9.7

9.7 
Summary of Calculated Values

(Continued)

\begin{tabular}{|c|c|c|c|c|}
\hline Run No. & $\mathrm{x}$ & $\begin{array}{l}\text { Holdup } \\
\mathrm{R}_{\mathrm{L}} \\
\end{array}$ & $\begin{array}{c}\text { Slip Velocity } \\
\text { Ft } / \text { Sec. } \\
V_{S} \\
\end{array}$ & $\begin{array}{c}\text { Pressure } \\
\mathrm{Lb} / \mathrm{Sq} \mathrm{Ft} \\
\mathrm{Ft} \text { of } \mathrm{Pi} \\
\triangle \mathrm{P}_{\mathrm{TP}} / \mathrm{I} \\
\end{array}$ \\
\hline \multicolumn{5}{|c|}{ Air-0il Blend No. I Runs (Continued) } \\
\hline 719 & 1.06 & 0.535 & 1.6 & 10.2 \\
\hline 720 & 0.64 & 0.454 & 2.7 & 11.7 \\
\hline 721 & 0.44 & 0.40 & 4.0 & 10.5 \\
\hline 722 & 0.31 & 0.353 & 5.5 & 11.0 \\
\hline 723 & 0.23 & 0.331 & 7.5 & 11.0 \\
\hline 724 & 0.153 & 0.294 & 12.1 & 11.7 \\
\hline 725 & 0.075 & 0.213 & 36.4 & 12.0 \\
\hline 726 & 0.0435 & 0.172 & 40.5 & 12.0 \\
\hline 727 & 0.0285 & 0.148 & 58.6 & 12.0 \\
\hline 728 & 0.0201 & 0.118 & 76.0 & 12.5 \\
\hline 729 & 0.0139 & 0.101 & 99.0 & 14.2 \\
\hline
\end{tabular}

$$
G=50
$$

$\begin{array}{lllll}732 & 10.1 & 0.93 & 0.85 & 2.7 \\ 733 & 4.0 & 0.84 & 1.15 & 6.5 \\ 734 & 2.7 & 0.775 & 1.3 & 9.0 \\ 735 & 1.9 & 0.69 & 1.3 & 7.7 \\ 736 & 1.51 & 0.653 & 1.7 & 8.5 \\ 737 & 0.91 & 0.533 & 2.4 & 9.5 \\ 738 & 0.62 & 0.461 & 3.4 & 9.7 \\ 739 & 0.435 & 0.411 & 5.15 & 11.5 \\ 740 & 0.325 & 0.35 & 6.5 & 12.2 \\ 741 & 0.218 & 0.286 & 10.0 & 14.0 \\ 742 & 0.111 & 0.233 & 21.4 & 16.7 \\ 743 & 0.0715 & 0.175 & 36.0 & 18.7 \\ 744 & 0.045 & 0.147 & 52.5 & 19.2 \\ 745 & 0.0335 & 0.130 & 70.5 & 20.0 \\ 746 & 0.0252 & 0.122 & 90.4 & 21.2\end{array}$

$G=100$

$\begin{array}{lclcr}700 & 18.6 & 0.922 & - & 3.2 \\ 701 & 7.6 & 0.88 & 0.8 & 4.7 \\ 702 & 5.1 & 0.85 & 1.4 & 6.0 \\ 703 & 3.64 & 0.785 & 1.3 & 6.5 \\ 704 & 3.0 & 0.749 & 1.5 & 7.2 \\ 705 & 1.73 & 0.647 & 2.3 & 10.0 \\ 706 & 1.22 & 0.563 & 2.9 & 10.5 \\ 707 & 0.85 & 0.485 & 4.0 & 13.0 \\ 708 & 0.64 & 0.42 & 5.1 & 14.5 \\ 709 & 0.43 & 0.345 & 7.9 & 17.5 \\ 710 & 0.222 & 0.274 & 17.5 & 25.2 \\ 711 & 0.134 & 0.218 & 30.2 & 30.0\end{array}$


Summary of Calculated Values

(Continued)

\begin{tabular}{|c|c|c|c|c|}
\hline Run No. & $x$ & $\begin{array}{c}\text { Holdup } \\
\mathrm{R}_{\mathrm{L}} \\
\end{array}$ & $\begin{array}{c}\text { Slip Velocity } \\
\text { Ft/Sec. } \\
V_{S} \\
\end{array}$ & $\begin{array}{c}\text { Pressure Drop } \\
\mathrm{Lb} / \mathrm{Sq} \text { Ft Per } \\
\text { Ft of Pipe } \\
\triangle \mathrm{PTP} / \mathrm{I} \\
\end{array}$ \\
\hline \multicolumn{5}{|c|}{ Air-0il Blend No. I Runs (Continued) } \\
\hline $\begin{array}{l}712 \\
713 \\
714\end{array}$ & $\begin{array}{l}0.095 \\
0.074 \\
0.057\end{array}$ & $\begin{array}{l}0.193 \\
0.168 \\
0.155\end{array}$ & $\begin{array}{l}45.5 \\
57.2 \\
75.0\end{array}$ & $\begin{array}{l}31.7 \\
34.0 \\
36.0\end{array}$ \\
\hline \multicolumn{5}{|c|}{$G=150$} \\
\hline $\begin{array}{l}750 \\
751 \\
752 \\
753 \\
754 \\
755 \\
756 \\
757 \\
758 \\
759 \\
760 \\
761 \\
762\end{array}$ & $\begin{array}{l}11.4 \\
7.5 \\
5.3 \\
4.35 \\
2.61 \\
1.7 \\
1.25 \\
0.97 \\
0.645 \\
0.332 \\
0.202 \\
0.155 \\
0.118\end{array}$ & $\begin{array}{l}0.909 \\
0.89 \\
0.846 \\
0.827 \\
0.73 \\
0.65 \\
0.575 \\
0.513 \\
0.407 \\
0.297 \\
0.246 \\
0.21 \\
0.193\end{array}$ & $\begin{array}{l}0.6 \\
1.6 \\
1.8 \\
2.4 \\
2.6 \\
3.7 \\
4.1 \\
5.2 \\
6.75 \\
13.6 \\
25.8 \\
34.5 \\
47.0\end{array}$ & $\begin{array}{r}4.5 \\
5.7 \\
7.0 \\
8.2 \\
10.5 \\
11.7 \\
14.7 \\
16.7 \\
20.7 \\
30.2 \\
34.7 \\
43.7 \\
49.0\end{array}$ \\
\hline
\end{tabular}


Summary of Calculated Values

(Continued)

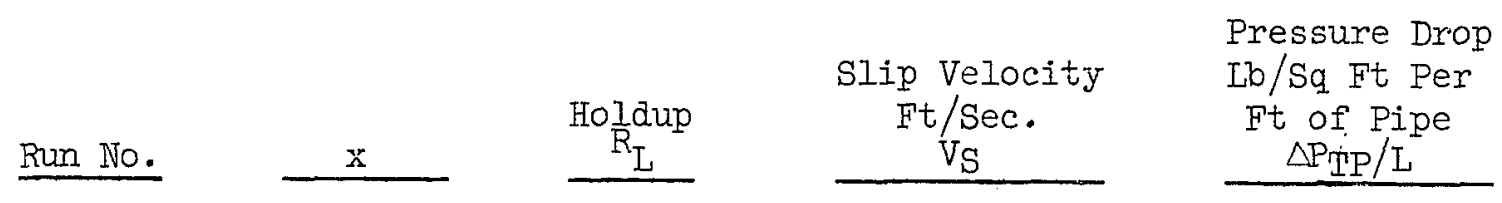

Air-Oil Blend No. 2 Runs

$$
G=25
$$

$\begin{array}{lllll}942 & 9.9 & 0.913 & 1.0 & 6.7 \\ 943 & 3.9 & 0.805 & 1.3 & 12.2 \\ 944 & 2.61 & 0.745 & 1.65 & 12.5 \\ 945 & 1.84 & 0.672 & 1.95 & 13.7 \\ 946 & 1.48 & 0.635 & 2.3 & 14.0 \\ 947 & 0.89 & 0.56 & 3.7 & 15.2 \\ 948 & 0.575 & 0.485 & 5.2 & 14.7 \\ 949 & 0.435 & 0.435 & 6.9 & 14.7 \\ 950 & 0.33 & 0.387 & 8.7 & 15.7 \\ 951 & 0.211 & 0.336 & 13.1 & 16.5 \\ 952 & 0.109 & 0.289 & 25.8 & 18.5 \\ 953 & 0.062 & 0.249 & 43.9 & 19.7 \\ 954 & 0.0415 & 0.196 & 60.6 & 21.0 \\ 955 & 0.0293 & 0.165 & 79.2 & 22.0 \\ 956 & 0.0207 & 0.129 & 97.7 & 24.0\end{array}$

$$
G=50
$$

$$
927
$$

928

929

930

931

932

933

934

935

936

937

938

939

940

941

$$
G=100
$$

13.5

5.35

3.65

2.56

2.07

1.22

0.805

0.6

0.46

0.3

0.153

0.092

0.0635

0.0465

0.0352
0.943

0.868

0.813

0.748

0.708

0.627

0.535

0.485

0.431

0.372

0.288

0.263

0.232

0.218

0.201
1.3

1.7

1.9

2.1

2.3

3.6

4.9

6.5

8.15

12.0

22.9

39.2

56.4

76.8

95.2
6.7

12.2

12.5

13.7

14.0

15.2

14.7

14.7

15.7

16.5

18.5

19.7

21.0

22.0

24.0

$\begin{array}{llllr}912 & 25.0 & 0.965 & 1.8 & 6.5 \\ 913 & 10.2 & 0.92 & 2.3 & 8.7 \\ 914 & 6.95 & 0.88 & 2.4 & 10.5 \\ 915 & 4.91 & 0.832 & 2.6 & 11.7 \\ 916 & 4.0 & 0.795 & 2.6 & 13.0 \\ 917 & 2.35 & 0.715 & 3.7 & 16.5\end{array}$


Summary of Calculated Values

(Continued)

\begin{tabular}{|c|c|c|c|c|}
\hline Run No. & $\mathrm{x}$ & $\begin{array}{c}\text { Holdup } \\
\mathrm{RL}_{\mathrm{L}} \\
\end{array}$ & $\begin{array}{c}\text { Slip Velocity } \\
\text { Ft/Sec. } \\
V_{S} \\
\end{array}$ & $\begin{array}{c}\text { Pressure Drop } \\
\text { Lb/Sq Ft Per } \\
\text { Ft of Pipe } \\
\Delta \mathrm{P}_{\mathrm{TP}} / \mathrm{L} \\
\end{array}$ \\
\hline \multicolumn{5}{|c|}{ Air-Oil Blend No. 2 Runs (Continued) } \\
\hline $\begin{array}{l}918 \\
919 \\
920 \\
921 \\
922 \\
923 \\
924 \\
925 \\
926\end{array}$ & $\begin{array}{l}1.54 \\
1.15 \\
0.88 \\
0.60 \\
0.31 \\
0.184 \\
0.133 \\
0.101 \\
0.0765\end{array}$ & $\begin{array}{l}0.653 \\
0.585 \\
0.493 \\
0.400 \\
0.325 \\
0.277 \\
0.221 \\
0.207 \\
0.21\end{array}$ & $\begin{array}{r}5.5 \\
6.6 \\
7.3 \\
9.7 \\
19.7 \\
34.1 \\
45.1 \\
59.8 \\
89.5\end{array}$ & $\begin{array}{l}19.7 \\
21.7 \\
23.7 \\
28.5 \\
37.2 \\
47.0 \\
50.5 \\
53.2 \\
55.7\end{array}$ \\
\hline \multicolumn{5}{|c|}{$G=150$} \\
\hline $\begin{array}{l}900 \\
901 \\
902 \\
903 \\
904 \\
905 \\
906 \\
907 \\
908 \\
909 \\
910 \\
911\end{array}$ & $\begin{array}{l}15.0 \\
10.2 \\
7.25 \\
5.95 \\
3.55 \\
2.35 \\
1.75 \\
1.32 \\
0.9 \\
0.475 \\
0.30 \\
0.208\end{array}$ & $\begin{array}{l}0.945 \\
0.895 \\
0.875 \\
0.86 \\
0.781 \\
0.72 \\
0.642 \\
0.58 \\
0.49 \\
0.367 \\
0.32 \\
0.277\end{array}$ & $\begin{array}{r}3.4 \\
1.9 \\
3.1 \\
4.2 \\
4.3 \\
6.0 \\
6.2 \\
7.5 \\
9.8 \\
17.2 \\
28.5 \\
42.3\end{array}$ & $\begin{array}{l}10.7 \\
12.2 \\
13.7 \\
15.5 \\
18.5 \\
20.0 \\
24.5 \\
28.0 \\
33.0 \\
45.0 \\
56.0 \\
61.2\end{array}$ \\
\hline
\end{tabular}




\begin{tabular}{|c|c|c|c|c|}
\hline Run No. & $\mathrm{x}$ & $\begin{array}{c}\text { Holdup } \\
\mathrm{RT}_{\mathrm{L}}\end{array}$ & $\begin{array}{c}\text { Slip Velocity } \\
\mathrm{Ft} / \mathrm{Sec} . \\
V_{\mathrm{S}}\end{array}$ & $\begin{array}{c}\text { Pressure Drop } \\
\mathrm{Lb} / \mathrm{Sq} \text { Ft Per } \\
\text { Ft of Pipe } \\
\triangle \mathrm{PTP} / \mathrm{L}\end{array}$ \\
\hline
\end{tabular}

Air-Trichloroethylene Runs

$G=37.5$

$\begin{array}{lllll}1013 & 1.62 & 0.70 & 0.5 & 14.0 \\ 1014 & 1.09 & 0.57 & 0.5 & 12.2 \\ 1015 & 0.74 & 0.487 & 0.75 & 10.2 \\ 1016 & 0.60 & 0.437 & 0.95 & 11.5 \\ 1017 & 0.35 & 0.336 & 1.7 & 11.7 \\ 1018 & 0.23 & 0.314 & 3.2 & 12.5 \\ 1019 & 0.172 & 0.266 & 4.3 & 16.0 \\ 1020 & 0.132 & 0.244 & 6.1 & 17.5 \\ 1021 & 0.075 & 0.216 & 10.0 & 18.2 \\ 1022 & 0.043 & 0.157 & 20.4 & 16.2 \\ 1023 & 0.0234 & 0.112 & 36.8 & 13.0 \\ 1024 & 0.016 & 0.078 & 50.9 & 13.0\end{array}$

$G=150$

$\begin{array}{lllll}1000 & 5.35 & 0.888 & 0.9 & 7.0 \\ 1001 & 3.53 & 0.818 & 0.7 & 6.2 \\ 1002 & 2.46 & 0.736 & 0.5 & 7.2 \\ 1003 & 2.0 & 0.685 & 0.6 & 9.0 \\ 1004 & 1.17 & 0.565 & 0.9 & 10.0 \\ 1005 & 0.77 & 0.455 & 1.5 & 11.7 \\ 1006 & 0.565 & 0.405 & 2.1 & 15.2 \\ 1007 & 0.423 & 0.352 & 3.4 & 19.0 \\ 1008 & 0.270 & 0.288 & 6.6 & 24.7 \\ 1009 & 0.151 & 0.221 & 13.4 & 32.5 \\ 1010 & 0.0915 & 0.165 & 24.3 & 36.2 \\ 1011 & 0.066 & 0.137 & 44.6 & 43.5 \\ 1012 & 0.050 & 0.132 & 47.5 & 42.0\end{array}$


APPENDIX D

Sample Calculations

Data for Run 307, Appendix A

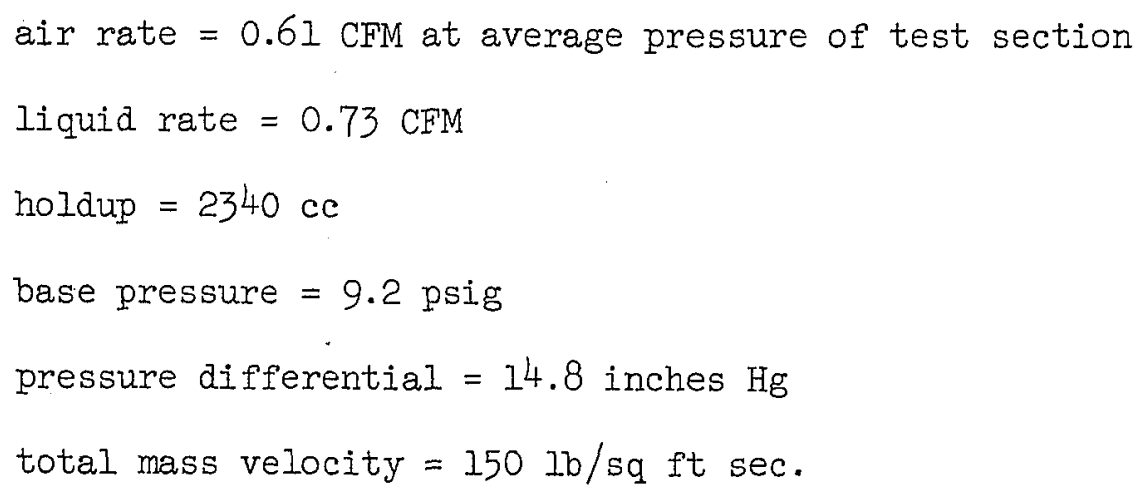

Iiquid Holdup, RI

Experimental Holdup

$$
\begin{aligned}
& \text { holdup + liquid between valve and drain }+ \text { liquid adhering to } \\
& \text { wall = total holdup } \\
& 2340+20+25=2385 \\
& \text { total volume of section }=3570 \mathrm{cc} \\
& \mathrm{R}_{\mathrm{L}}=\frac{2385}{3570}=0.666
\end{aligned}
$$

Calculated Holdup

$$
\begin{aligned}
& x=\left(\frac{W_{L}}{W_{G}}\right)^{0.9} \frac{\mu_{L}^{0.19} \sigma^{0.205} \rho_{G}^{0.70}}{G^{0.435} \rho_{L}^{0.72}} \\
& \rho_{L}=74.0 \mathrm{Ib} / \mathrm{cu} \mathrm{ft} \\
& \mu_{\mathrm{L}}=3.15 \text { centipoises } \\
& \sigma=75.9 \mathrm{dynes} / \mathrm{cm} \\
& G=150 \mathrm{Ib} / \mathrm{sq} \mathrm{ft} \text { sec. } \\
& \text { As } G \text { is greater than } 50, \text { use } 50
\end{aligned}
$$

For $\rho_{G}$ (air density at average test section conditions) 
pressure at base of test section $=9.2 \mathrm{psig}$

pressure differential for test section $=14.8$ inches $\mathrm{Hg}$ or

7.25 psi

pressure at top of test section $=9.2-7.25=1.95$ psig

average pressure in test section $=\frac{9.2+1.95}{2}=5.58$ psig

air density at $75^{\circ} \mathrm{F}$ and $14.7 \mathrm{psig}=\frac{(28.8)(520)}{(379)(535)}=0.074 \mathrm{Ib} / \mathrm{cu}$ ft

28.8 = molecular weight of air

$379=$ volume of one mol of gas at $520^{\circ} \mathrm{R}$ and $14.7 \mathrm{psig}$

535 = air temperature ${ }^{\circ} \mathrm{F}$

$\rho_{G}=\frac{(0.074)(14.7+5.58)}{14.7}=0.1021 \mathrm{~b} / \mathrm{cu} \mathrm{ft}$

$W_{G}=0.61 \rho_{G}=(0.61)(0.102)=0.0622 \mathrm{Ib} / \mathrm{min}$.

$W_{L}=0.73 \rho_{L}=(0.73)(74)=54 \mathrm{Ib} / \mathrm{min}$.

$x=\left(\frac{54}{0.0622}\right)^{0.9} \frac{(3.15)^{0.19}(75.9)^{0.205}(0.102)^{0.70}}{(50)^{0.435}\left(7^{4}\right)^{0.72}}$

$x=2.3$

From Figure 12 for $x=2.3$, calculated $R_{\mathrm{L}}=0.71$

Actual $R_{L}$ - calculated $R_{L}=0.666-.71=.044$

Pressure Drop, $\triangle \mathrm{PTP}$

Experimental Pressure Drop

$$
\begin{aligned}
& \left(Z_{2}-Z_{I}\right)\left(\frac{W_{L}+W_{G}}{W_{L} V_{L}+W_{G V}^{V} G}\right)+p_{2} p_{I}+\Delta P_{T P}=0 \\
& z_{2}-z_{I}=20 \mathrm{ft} \\
& \mathrm{v}_{I}=\frac{1}{\rho L}=0.0135 \mathrm{cu} \mathrm{ft} / 1 \mathrm{~b} \\
& v_{G}=\frac{I}{\rho_{G}}=\frac{I}{0.102}=9.8 \mathrm{cu} \mathrm{ft} / \mathrm{Ib} \\
& p_{2}-p_{1}=-7.25 \text { psi or. }-1040 \text { psf }
\end{aligned}
$$




$$
\begin{gathered}
\text { (20) }\left[\frac{54+0.062}{(54)(0.0135)+(0.062)(9.8)}\right]-1040+\Delta P_{\mathrm{TP}}=0 \\
\Delta \mathrm{P}_{\mathrm{TP}}=1040-810=230 \mathrm{Ib} / \mathrm{sq} \mathrm{ft}
\end{gathered}
$$

Calculated Pressure Drop

$$
\begin{aligned}
& \psi=\frac{1}{\mu_{L}^{0.149} 0^{0.194} G^{0.70}} \\
& \psi=\frac{1}{(3.15)^{0.149}(75.9)^{0.194}(150)^{0.70}} \\
& \psi=0.011
\end{aligned}
$$

Liquid velocity in pipe

$$
\text { flow rate }=\frac{54}{60 \times 74}=0.0122 \mathrm{cu} \mathrm{ft} / \mathrm{sec} \text {. }
$$

cross sectional area of pipe $=0.006 \mathrm{sq} \mathrm{ft}$

$$
\begin{aligned}
& \text { area for liquid flow }=0.006 \mathrm{R}_{\mathrm{L}}=0.004 \mathrm{sq} \mathrm{ft} \\
& \text { liquid velocity }=\frac{0.0122}{0.004}=3.05 \mathrm{ft} / \mathrm{sec} .
\end{aligned}
$$

Gas velocity in pipe

$$
\begin{gathered}
\text { flow rate }=\frac{0.0622}{60 \times 0.102}=0.01015 \mathrm{cu} \mathrm{ft} / \mathrm{sec} . \\
\text { area for gas flow }=0.006\left(1-\mathrm{R}_{\mathrm{L}}\right)=0.002 \mathrm{sq} \mathrm{ft} \\
\text { gas velocity }=\frac{0.0105}{0.002}=5.25 \mathrm{ft} / \mathrm{sec} . \\
\text { Slip velocity, } \mathrm{V}_{\mathrm{S}},=5.25-3.05=2.2 \mathrm{ft} / \mathrm{sec} . \\
\text { From Figure } 28 \text { for } \mathrm{V}_{\mathrm{S}}=2.2, \psi=0.011 \\
\frac{\Delta P T P-\triangle P I}{\mathrm{~L}}=8 \mathrm{Ib} / \mathrm{sq} \text { ft per ft of pipe }
\end{gathered}
$$

For total liquid flow at $G=150 \mathrm{lb} / \mathrm{sq} \mathrm{ft} \mathrm{sec}$.

$$
R_{e}=\frac{D G}{\mu}=\frac{(0.0875)(150)(3600)}{(3.15)(2.42) .}=6200
$$

From Figure 3, at $R_{e}=6200 \quad f=0.0375$

$$
\begin{aligned}
& \Delta \mathrm{P}_{\mathrm{L}}=\frac{f \mathrm{I} \mathrm{G}^{2}}{2 \mathrm{Dg} P}=\frac{(0.0375)(\mathrm{I})(150)^{2}}{(2)(0.0875)(32.2)(74)}=2.0 \mathrm{lb} / \mathrm{sq} \mathrm{ft} \\
& \Delta \mathrm{P}_{\mathrm{TP}}=8+2=10 \mathrm{Ib} / \mathrm{sq} \text { ft per ft for } 20 \mathrm{ft} \text { of } \\
& \text { pipe }=200 \mathrm{Ib} / \mathrm{sq} \mathrm{ft}
\end{aligned}
$$


Total pressure drop $=810+200=1010 \mathrm{lb} / \mathrm{sq} \mathrm{ft}$

$\%$ error between observed and calculated $=\frac{1040-1010}{1040}=3 \%$ 
Gordon A. Hughmark was born in Cleveland, Ohio on July 15, 1924. Grade school and high school educations were obtained in Cincinnati, ohio. He graduated from the University of Cincinnati in 1947 with the degree of Chemical Engineer. Graduate work at Louisiana State University from 1951 to 1955 led to the M.S. degree in Chemical Engineering in 1955.

He was employed as a Chemical Engineer by the Vulcan Copper and Supply Company, Cincinnati, Ohio from 1947 to 1951 and by the Ethyl Corporation, Baton Rouge, Louisiana from February 1951 to the present. 
Candidate: Gordon A. Hughmarl.

Major Field:

Title of Thesis:

Holdup and Pressure Drop with Gas-Liquid Flow in A Vertical Pipe.

Approved:

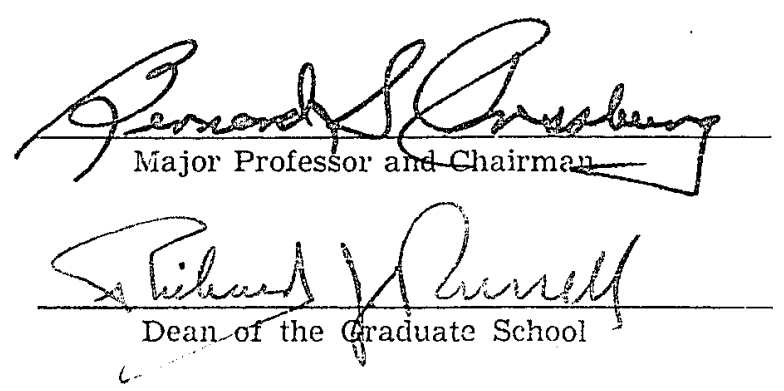

EXAMINING COMMITTEE:

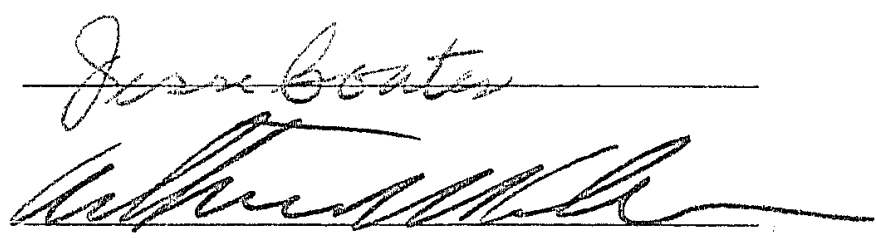

Date of Examination:

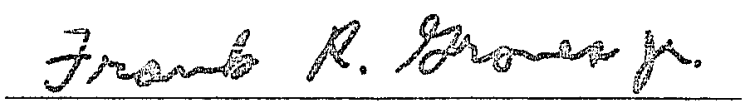

